San Jose State University

SJSU ScholarWorks

Master's Theses

Master's Theses and Graduate Research

Spring 2015

\title{
Petrology and Sequence Stratigraphy Of A Portion Of The Lost \\ Burro Formation, Death Valley, California
}

Rachel Unger

San Jose State University

Follow this and additional works at: https://scholarworks.sjsu.edu/etd_theses

\section{Recommended Citation}

Unger, Rachel, "Petrology and Sequence Stratigraphy Of A Portion Of The Lost Burro Formation, Death Valley, California" (2015). Master's Theses. 4563.

DOI: https://doi.org/10.31979/etd.2bkd-y5ms

https://scholarworks.sjsu.edu/etd_theses/4563

This Thesis is brought to you for free and open access by the Master's Theses and Graduate Research at SJSU ScholarWorks. It has been accepted for inclusion in Master's Theses by an authorized administrator of SJSU ScholarWorks. For more information, please contact scholarworks@sjsu.edu. 
PETROLOGY AND SEQUENCE STRATIGRAPHY OF A PORTION OF THE LOST BURRO FORMATION, DEATH VALLEY, CALIFORNIA

\author{
A Thesis \\ Presented to \\ the Faculty of the Department of Geology \\ San José State University \\ in Partial Fulfillment \\ of the Requirements for the Degree \\ Master of Science
}

by

Rachel Unger

May 2015 
(C) 2015

Rachel Unger

ALL RIGHTS RESERVED 
The Dedicated Thesis Committee Approves the Thesis Titled

PETROLOGY AND SEQUENCE STRATIGRAPHY OF A PORTION OF THE LOST BURRO FORMATION, DEATH VALLEY, CALIFORNIA

by

Rachel Unger

APPROVED FOR THE DEPARTMENT OF GEOLOGY

SAN JOSÉ STATE UNIVERSITY

May 2015
Dr. David Andersen
Department of Geology
Dr. Calvin Stevens
Department of Geology
Dr. Jonathan Hendricks
Department of Geology 


\section{ABSTRACT \\ PETROLOGY AND SEQUENCE STRATIGRAPHY OF A PORTION OF THE LOST BURRO FORMATION, DEATH VALLEY, CALIFORNIA}

by Rachel Unger

An in-depth study of a 9.6-m interval within the Lost Burro Formation, exposed in Death Valley National Park, California, was undertaken in order to ascertain whether or not the banding within the unit represents systematic changes in the depositional environments. In the course of this study, 57 thin sections were made and examined, resulting in the identification of six Standard Microfacies (SMFs) in the measured section. The carbonate rocks were interpreted to preserve a range of environments from shallow subtidal normal marine environments, lagoons or restricted marine environments, and tidal channels to intertidal flats, upper intertidal ponds and supratidal flats. The sandstones were interpreted to preserve supratidal environments. Combining this information with field observations, seven complete parasequences were delineated. Of them, two were interpreted to represent upward-shallowing parasequences, whereas five others showed intra-sequence deepening. Systematic changes in depositional environments were not identified. These data were more completely described by a parasequence definition that allows for intra-sequence deepening rather than a straightforward shallowing upward definition. 


\section{ACKNOWLEDGEMENTS}

I'm sure it's been paraphrased before that no project is an island, but my thesis would not be in this condition without the contributions of a number of people. First, I'd like to thank Dr. David Andersen for his unstinting support and availability, his constructive criticism, and all those evenings and weekends that he spent with this thesis. My other committee members also deserve my gratitude for their contributions. In particular, my thanks to Dr. Jonathan Hendricks for getting the reference to The Shining in an early draft of the abstract, and to Dr. Calvin Stevens for lending me all those books/articles and never once asking when I would return them. I would like to thank the National Park Service and Death Valley National Park for allowing me to sample and do my field work within the park boundaries. I would also like to thank the Vernon girls for their boundless enthusiasm regarding my finishing this project. Finally, I would like to thank Alex Eiser for his endless patience, his encouragement, his skill at bludgeoning various programs into obedience, and for his insistence that I learn to use OmniGraffle. I'm so very lucky and grateful to have you in my life. 


\section{TABLE OF CONTENTS}

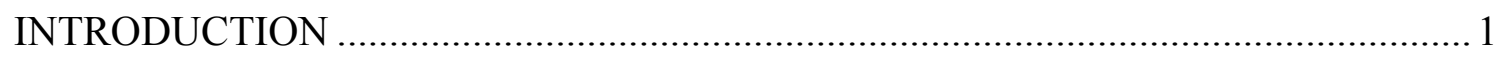

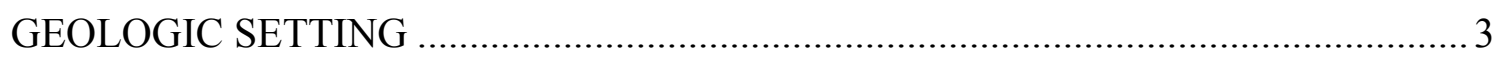

Lost Burro Formation Exposures........................................................... 3

Stratigraphy, Lithology, and Paleoenvironmental Indicators ........................... 5

Paleozoic Rocks within Lost Burro Gap ............................................ 5

Lost Burro Formation ................................................................ 5

Paleoenvironmental Indicators.................................................... 12

Overview of Carbonate Sequence Stratigraphy........................................... 16

Paleoenvironment and Depth Controls .................................................. 17

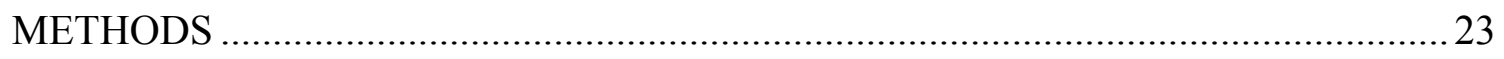

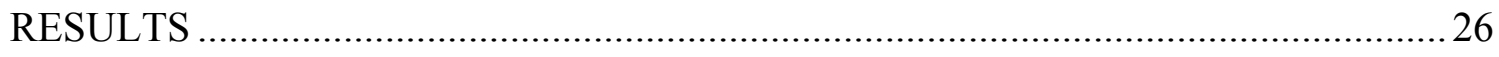

Field Observations ............................................................................... 26

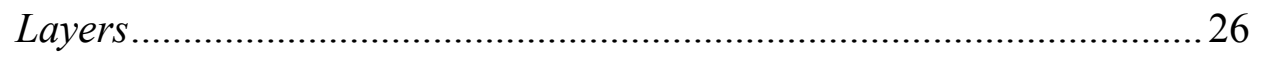

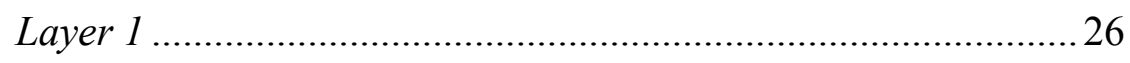

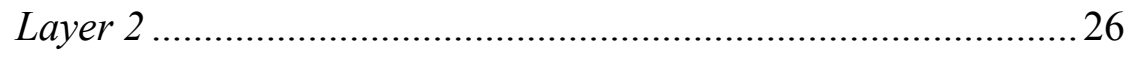

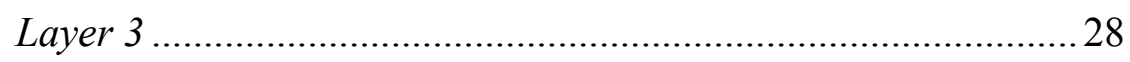

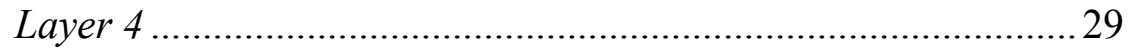

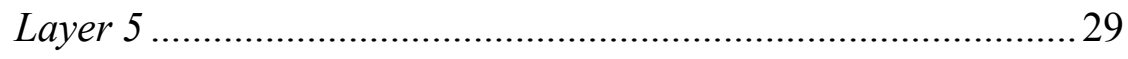

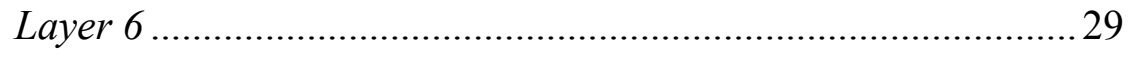

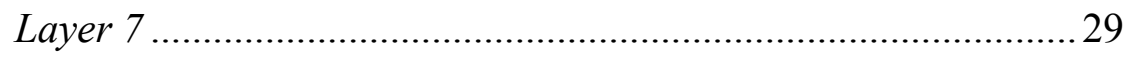

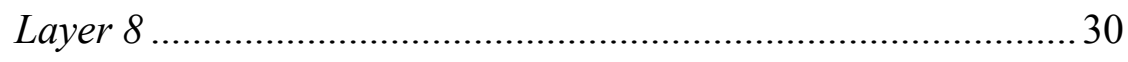




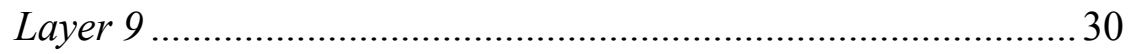

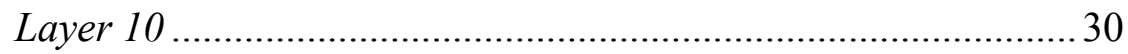

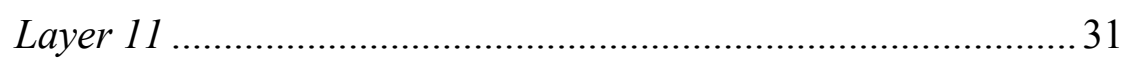

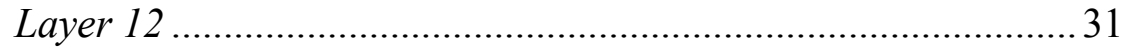

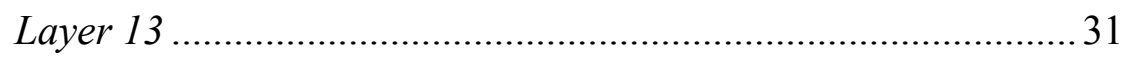

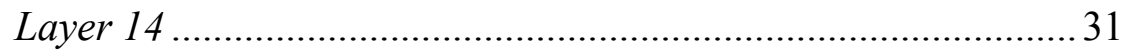

Layer 15 ...................................................................... 32

Layer 16 ......................................................................... 32

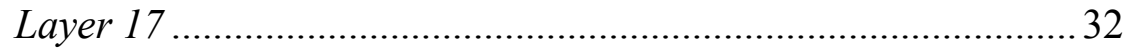

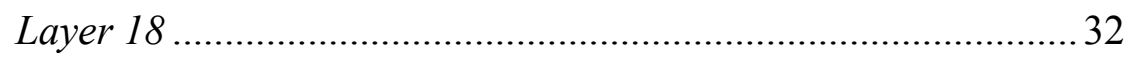

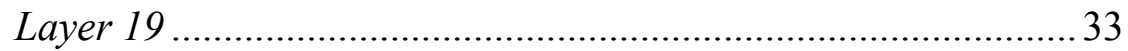

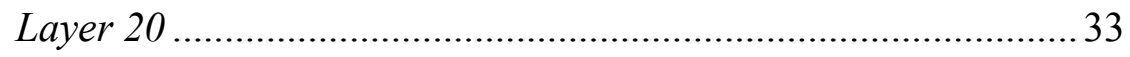

Layer 21 ...................................................................... 33

Striped Appearance .................................................................... 33

Carbonate Standard Microfacies ................................................................... 34

Criteria for Standard Microfacies Assignments .................................. 34

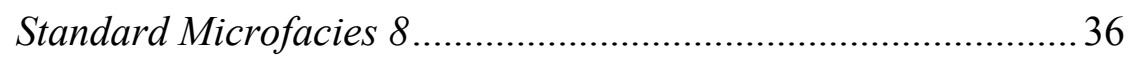

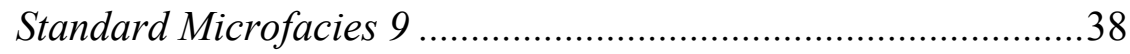

Standard Microfacies 16 .................................................. 40

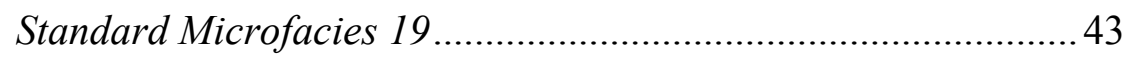

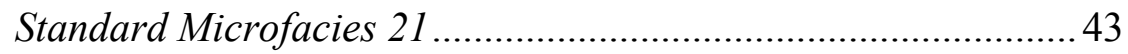

Standard Microfacies 23 .................................................. 45 


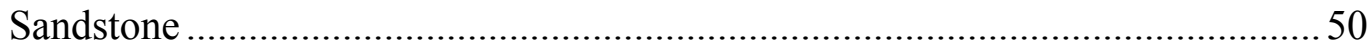

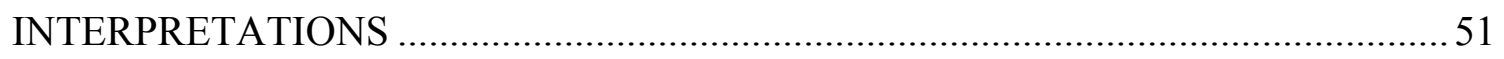

Inferred Depositional Environments................................................................... 51

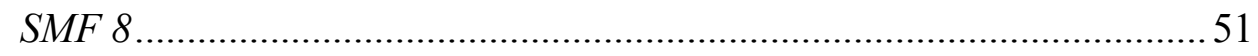

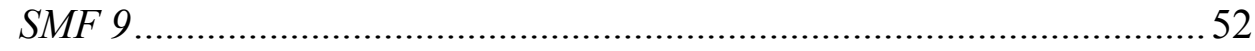

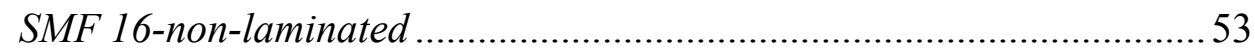

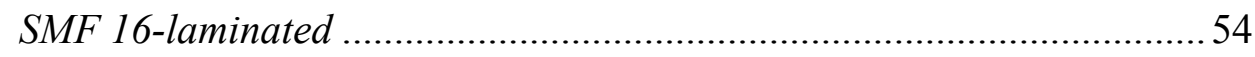

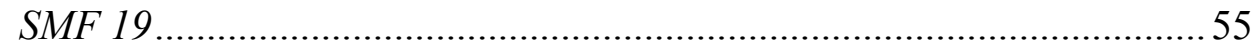

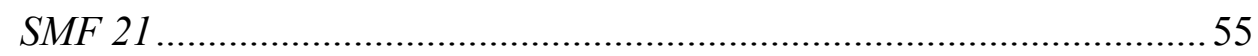

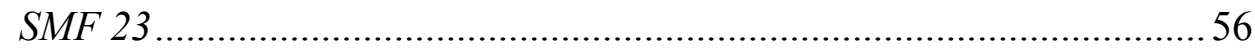

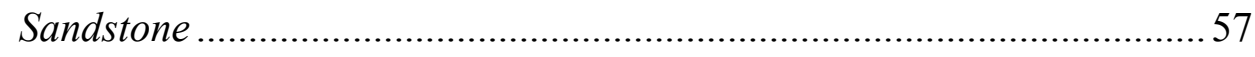

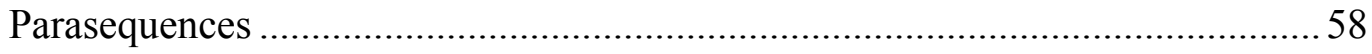

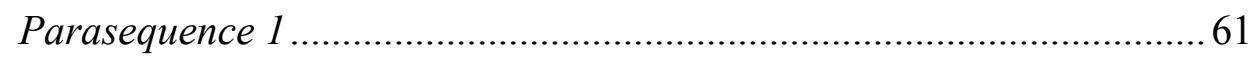

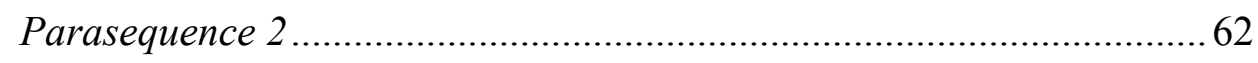

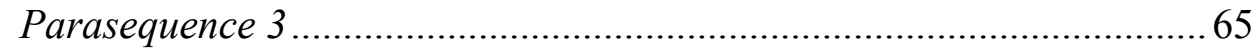

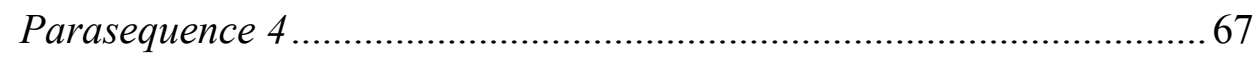

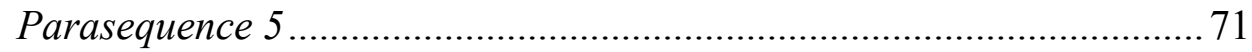

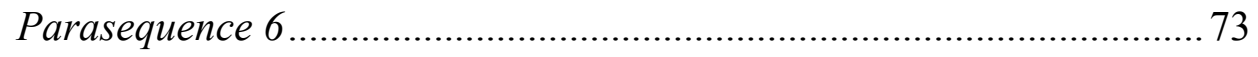

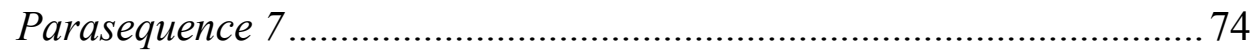

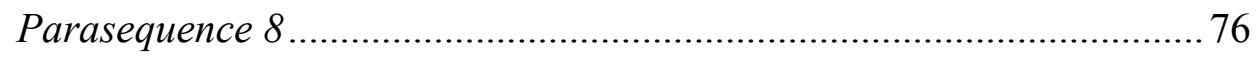

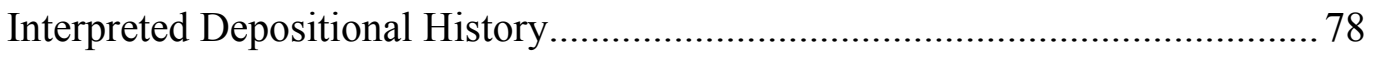




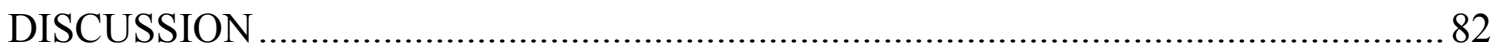

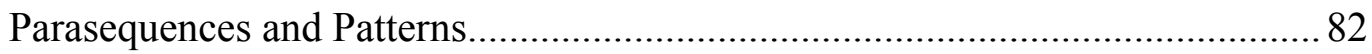

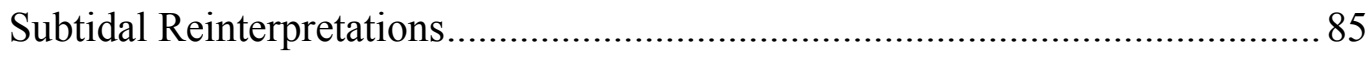

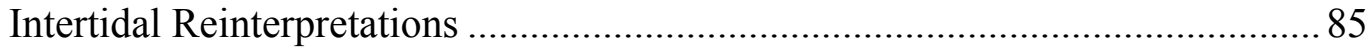

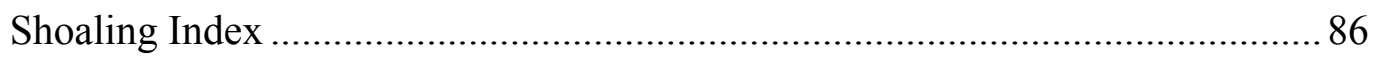

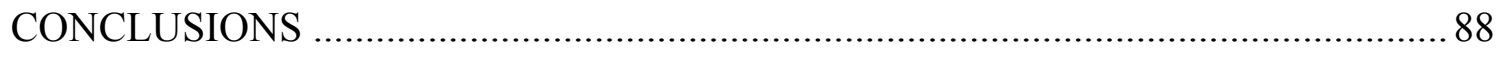

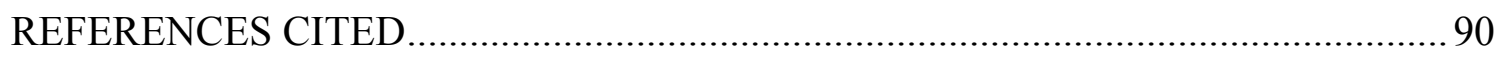

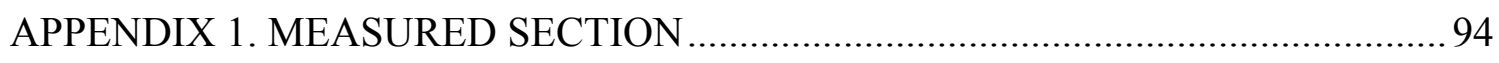

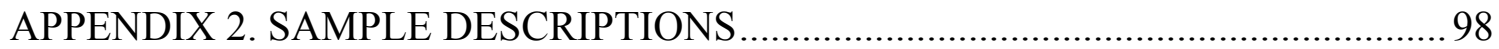




\section{LIST OF FIGURES}

Figure

1. Lost Burro Gap location. Map generated using the National Map database (U.S. Geological Survey, 2014). The inset map of California was adapted from the Wikipedia article on Inyo County (Benbennick, 2006).

2. Locations of exposures of Lost Burro Formation and equivalent units mentioned in the text (modified from Stevens, 1991). CMC = Central Mazourka Canyon, EIM $=$ Eastern Inyo Mountains, LBG $=$ Lost Burro Gap, SMC = South Mazourka Canyon, $\mathrm{TCH}=$ Talc City Hills......................................................................... 4

3. Lost Burro Gap geology (modified from McAllister, 1956, courtesy of U.S. Geological Survey). Mtm = Tin Mountain Limestone (Mississippian), Dlb = Lost Burro Formation (Devonian), dshv = Hidden Valley Dolomite (SilurianDevonian). Red dot marks measured section.

4. Variations in bed coloration in the Lost Burro Formation on the northeast side of Lost Burro Gap. Prominent dark limestone bed marked by red arrows on middle right is $1.9 \mathrm{~m}$ thick.

5. Amphipora, Lost Burro Formation in Lost Burro Gap (pencil ferrule $1.4 \mathrm{~cm}$ long). 8

6. Massive stromatoporoid in Lost Burro Formation (rock hammer head about $18 \mathrm{~cm}$ long).

7. Massive stromatoporoids in Lost Burro Formation (rock hammer head about $18 \mathrm{~cm}$ long).

8. The rugose coral Diphyphyllum, Lost Burro Formation (camera case $12.5 \mathrm{~cm}$ tall).

9. Favositid tabulate coral, Lost Burro Formation (pen cap $0.8 \mathrm{~cm}$ from rightmost cap edge to cap ridge at left of embossed pen logo).

10. Rugose corals (red arrow) and Amphipora (yellow arrow) in Lost Burro Formation (full black and white arrow is $10 \mathrm{~cm}$ tall).

11. Units 4 and 5, Lost Burro Formation, and Tin Mountain Limestone, northeast side of Lost Burro Gap (field assistant in lower right is $172 \mathrm{~cm}$ tall). Contact is at base of dark brown limestone layer (red arrow) 
12. View of measured section (red arrows), northeast side of Lost Burro Gap. Measured section is $9.6 \mathrm{~m}$ thick.

13. Measured section with sample locations, field observations, and some features observed in thin section.

14. Discontinuous sandstone layer (Layer 2). Field notebook is $19 \mathrm{~cm}$ tall. Base of layer is marked by base of field notebook

15. Variations in bed resistance, northeast side of Lost Burro Gap (gray limestone unit underneath weathered layer is $55 \mathrm{~cm}$ thick).

16. SMF 8, from thin section 112412-03, containing transverse (above) and longitudinal (below) section of Amphipora. Field of view is $1.16 \mathrm{~mm}$ wide...... 38

17. SMF 9, from thin section LBG13B, showing a brachiopod in micrite (field of view is $1.16 \mathrm{~mm}$ wide).

18. SMF 16, from thin section LBG40BB, showing micritic intraclasts and Tentaculites (red arrow). Field of view is $1.16 \mathrm{~mm}$ wide.

19. SMF 19, from thin section LBG3B, showing laminated micrite (field of view is $2.96 \mathrm{~mm}$ wide)

20. SMF 21, from thin section LBG43B, showing a fenestral opening (red arrow) and sandstone layer in micrite (field of view is $2.96 \mathrm{~mm}$ wide).

21. SMF 23, from thin section LBG9B, showing unlaminated micrite (field of view is $1.16 \mathrm{~mm}$ wide)

22. Measured section with sample locations and inferred depth line. Red lines mark parasequence boundaries, and triangles mark sample locations.

23. Sandstone lens (red arrows) overlain by stromatoporoid-bearing limestone in Parasequence 3 (field notebook is $19 \mathrm{~cm}$ tall). Stromatoporoid is black and fanshaped, tapering to a point at top right corner of field notebook (middle of opposite side of stromatoporoid marked by yellow arrow).

24. Sand lens (red arrow) above field notebook in Parasequence 4 (field notebook 19 $\mathrm{cm}$ from left to right).

25. Rugose corals (red arrows) in Parasequence 5 (black arrow head $5 \mathrm{~cm}$ tall)...... 72

26. Thin section LBG44BB, showing dark micritic intraclasts in spar (field of view is $1.16 \mathrm{~mm}$ wide) 


\section{LIST OF TABLES}

Table

1. Thicknesses of Lost Burro Formation units (from McAllister, 1952) ................. 6

2. Standard Microfacies classifications of carbonate thin sections ......................... 37

3. Munsell colors associated with Lost Burro Formation Standard Microfacies

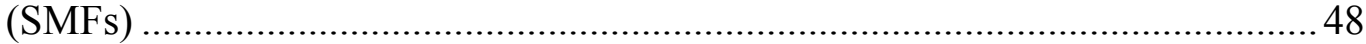

4. Munsell colors associated with Standard Microfacies (SMF) 16 ......................49

5. Sample classifications showing parasequence assignments ............................59

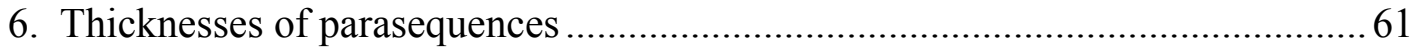

7. Environmental transitions within the Lost Burro Gap measured section............84 


\section{INTRODUCTION}

The Devonian Lost Burro Formation, as exposed in Death Valley National Park, California, is a strikingly banded unit composed primarily of carbonates with minor interbeds of quartz sandstone. In this area, the Lost Burro Formation is interpreted to preserve a shallow shelf environment (Stevens, 1986). The repetition of the bands within the formation has been inferred to be the result of Milankovitch cycles (Yang et al., 1995) based on peak matching between spectral analysis of the Lost Burro Formation bed thicknesses and eight of the Milankovitch peaks for eccentricity, precession and obliquity index cycles. Wilkinson et al. (1996) countered that the framework employed by Yang et al. (1995) in their work was too small to make a statistically significant determination of allogenic forcing. No studies since have returned to this question concerning these rocks. The present study, based on exposures in Lost Burro Gap (Fig. 1), was conducted in order to clarify whether the Lost Burro Formation contains deposits representing repeating sequences of paleoenvironments, and if so whether identification of a larger number of sub-environments would confirm the results reported by Yang et al. (1995).

The present investigation involves a detailed examination of a 9.6-m-thick interval in the middle of the Lost Burro Formation. The purpose of this research is

1) to determine the depositional environments recorded in this interval,

2) to determine if the depositional environments conform to a predictable sequence, and 


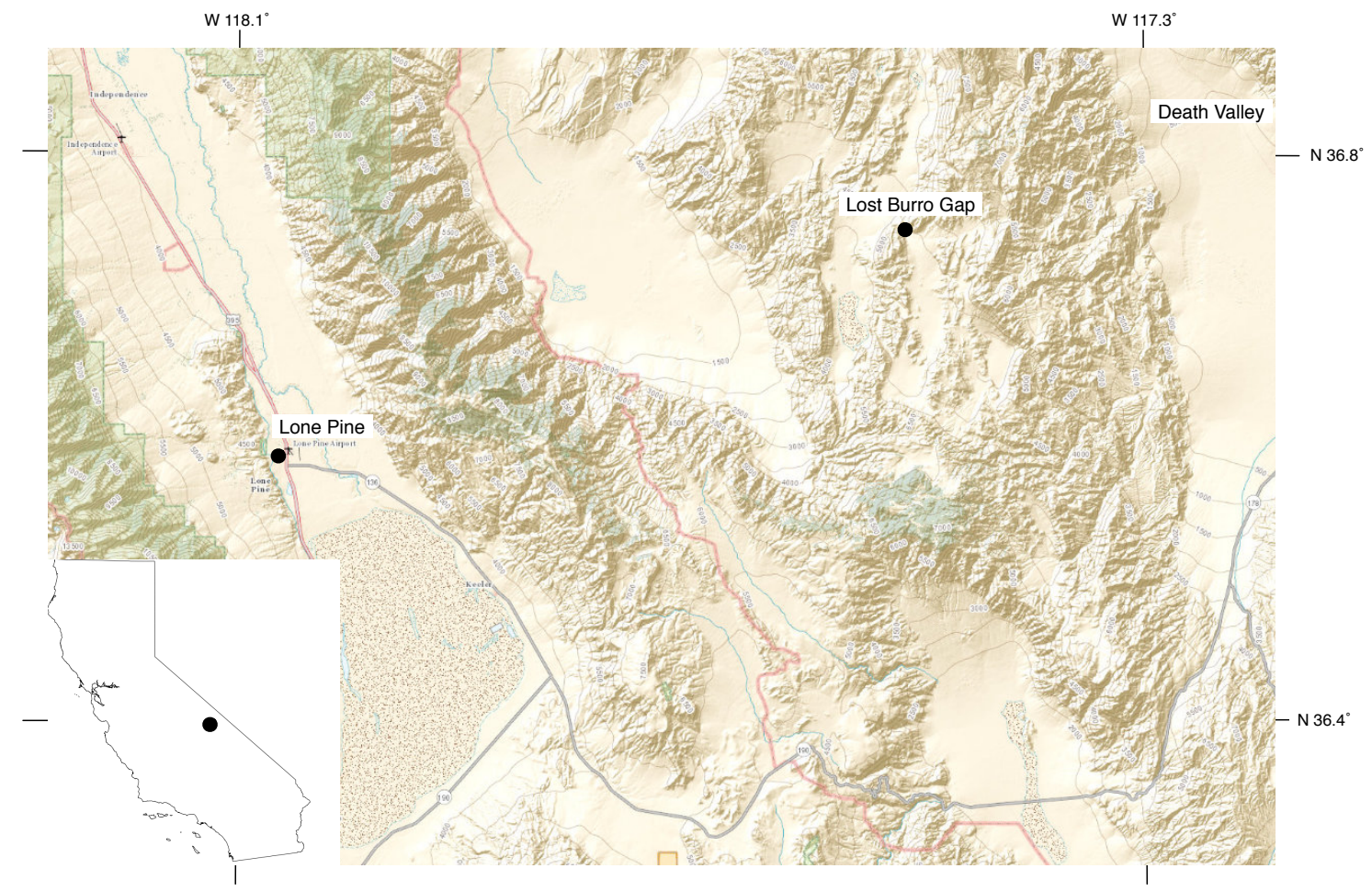

Figure 1. Lost Burro Gap location. Map generated using the National Map database (U.S. Geological Survey, 2014). The inset map of California was adapted from the Wikipedia article on Inyo County (Benbennick, 2006).

3) if a predictable sequence is detected, to evaluate the assertions of Wilkinson et al. (1996) regarding stochastic dominance in the paleoenvironmental controls.

The results of this study will provide a greater understanding of the Devonian paleoenvironments in southeastern California and help evaluate the validity of the model of Yang et al. (1995). 


\section{GEOLOGIC SETTING}

\section{Lost Burro Formation Exposures}

The Lost Burro Formation was deposited during the Middle to Late Devonian, in the western part of the Cordilleran miogeocline. In the Death Valley region, this unit has been considered to represent a shallow shelf deposit (Stevens, 1986), based on the presence of shallow-water fossils. In the Talc City Hills and eastern Inyo Mountains (Fig. 2), the Lost Burro Formation is predominantly composed of carbonate shelf deposits. In southern Mazourka Canyon, a base-of-slope environment is indicated to the west in the coeval Vaughn Gulch Limestone by the presence of debris-flow deposits that brought shallow-water fossils to deeper environments (Stevens, 1991). Farther northwest in central Mazourka Canyon the coeval Sunday Canyon Limestone indicates deposition in relatively deep water (Stevens, 1986). The top of the slope during the Devonian is therefore thought to lie between the western Talc City Hills and the southern end of Mazourka Canyon. Figure 2 shows the respective locations of these deposits.

The type locality for the Lost Burro Formation is at Lost Burro Gap, the site of this study, in the western part of Death Valley National Park. It is shown in Figures 1 and 2 relative to major highways and towns as well as Owens Lake and Death Valley.

The outcrops of the Lost Burro Formation in Lost Burro Gap were selected because they show less alteration than other nearby locations where the formation is exposed, such as in the Talc City Hills (Stevens, 1986, 1991). 


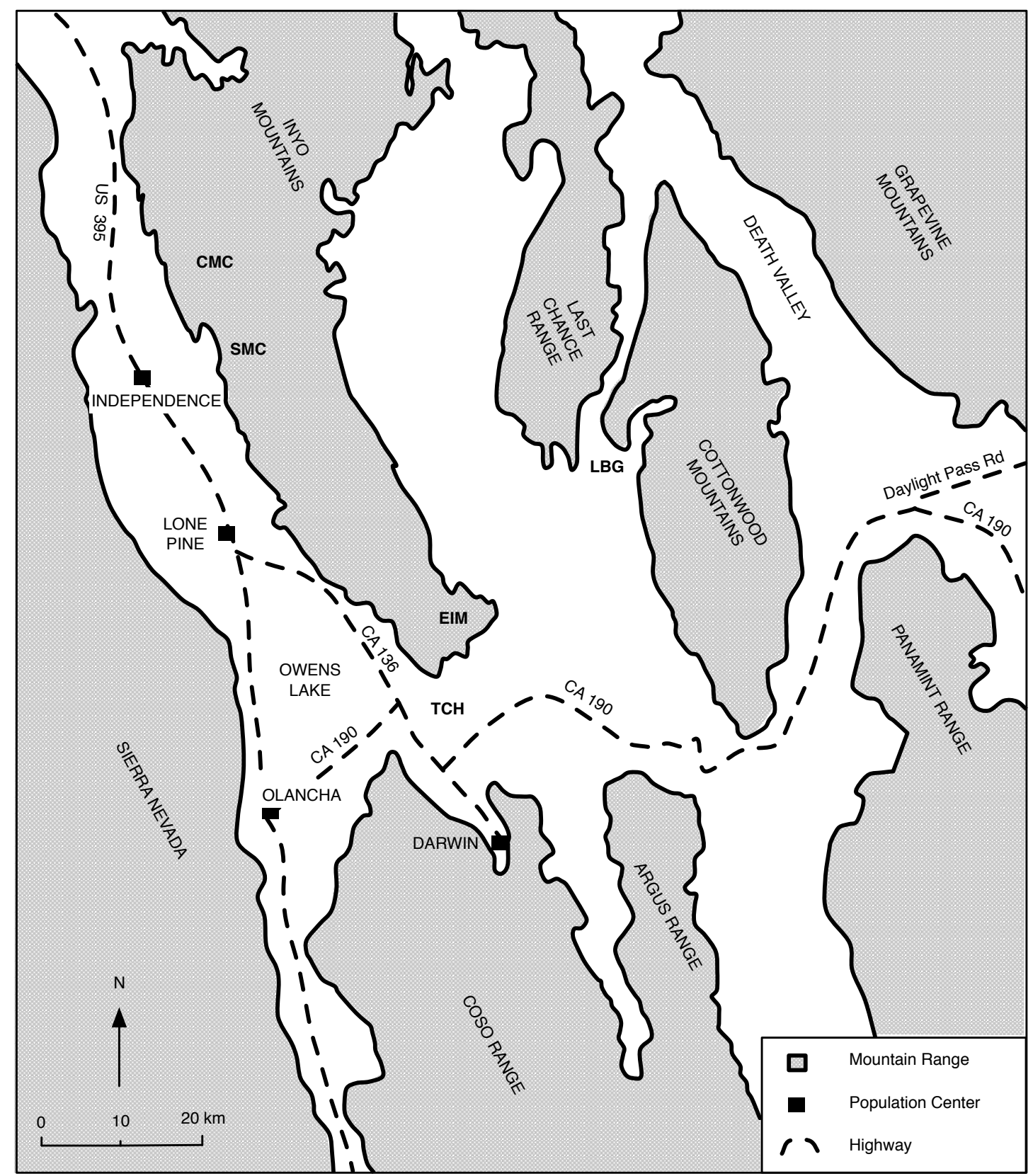

Figure 2. Locations of exposures of Lost Burro Formation and equivalent units mentioned in the text (modified from Stevens, 1991). CMC = Central Mazourka Canyon, $\mathrm{EIM}=$ Eastern Inyo Mountains, $\mathrm{LBG}=$ Lost Burro Gap, SMC = South Mazourka Canyon, $\mathrm{TCH}=$ Talc City Hills. 


\section{Stratigraphy, Lithology, and Paleoenvironmental Indicators}

\section{Paleozoic Rocks within Lost Burro Gap}

McAllister (1952) conducted the first detailed geologic work in Lost Burro Gap and the surrounding Quartz Spring area. In that report, he named, described, and mapped rocks that range in age from Cambrian to Pennsylvanian (McAllister, 1952), including the Lost Burro Formation. Figure 3 shows the geology at the type locality.

Within Lost Burro Gap, the Lost Burro Formation lies conformably between the Silurian Hidden Valley Dolomite and the Mississippian Tin Mountain Limestone. Collectively, these units include limestone, dolomite, and some quartzite. The focus of this investigation is an interval within the Lost Burro Formation.

\section{Lost Burro Formation}

The Lost Burro Formation forms the bulk of the outcrops within Lost Burro Gap. McAllister (1952) divided the Lost Burro Formation into five separate units. Table 1 shows the subdivisions of the Lost Burro Formation. The oldest unit is referred to as the Lippincott Member. This unit is a sandy grey dolomite containing brown-weathering sandstone beds. In some places, the quartz is concentrated into beds of vitreous quartzite. This unit also contains irregular chert nodules. McAllister (1952) measured this unit at $47.2 \mathrm{~m}(155 \mathrm{ft})$ thickness at the type locality in Lost Burro Gap.

Unit 2 of the Lost Burro Formation is lighter in color than Unit 1. It is composed of dolomite that is cream to light grey in color (McAllister, 1952). Some patches of dark mottled dolomite also occur. This unit is $143 \mathrm{~m}(470 \mathrm{ft})$ in thickness at the type locality (McAllister, 1952). 


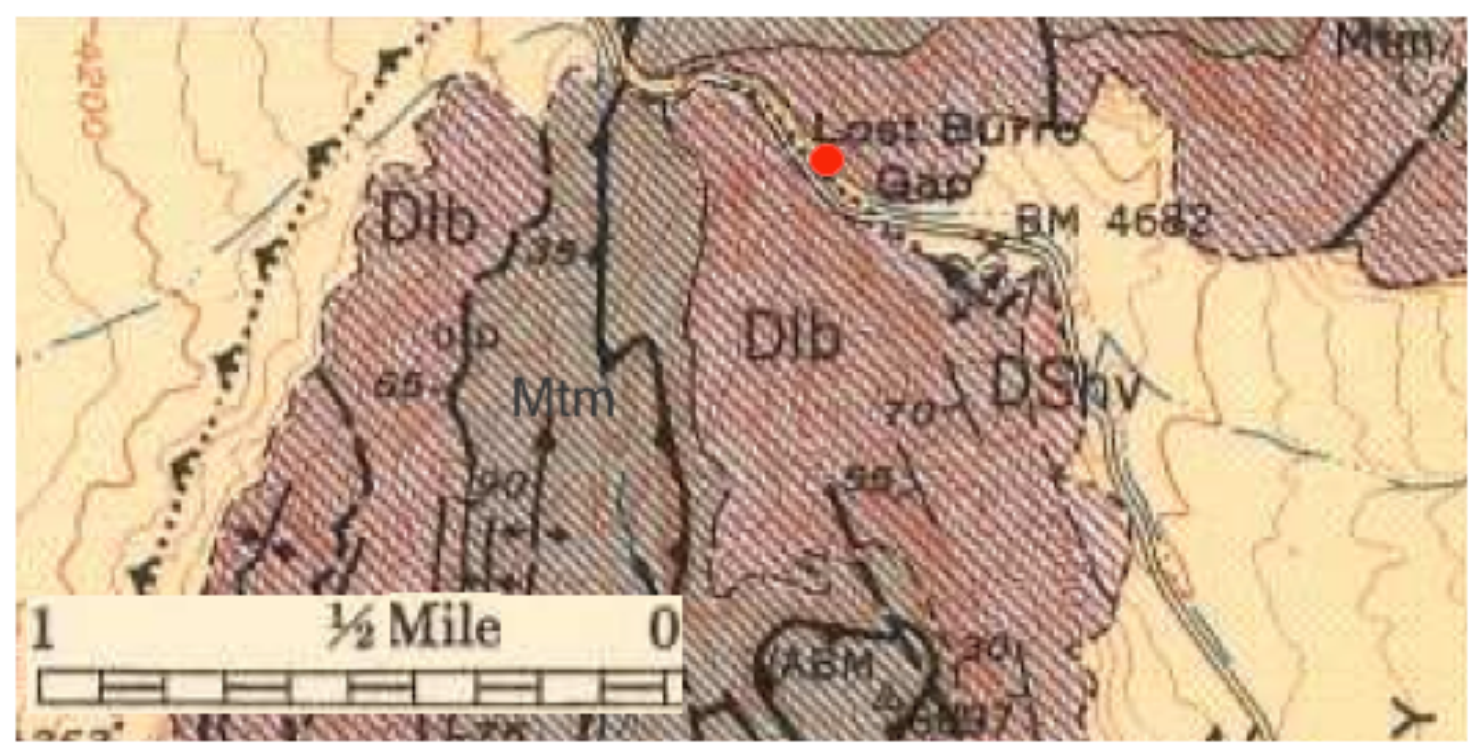

Figure 3. Lost Burro Gap geology (modified from McAllister, 1956, courtesy of U.S. Geological Survey). Mtm = Tin Mountain Limestone (Mississippian), Dlb = Lost Burro Formation (Devonian), DShv = Hidden Valley Dolomite (Silurian-Devonian). Red dot marks measured section.

TABLE 1. THICKNESSES OF LOST BURRO FORMATION UNITS (FROM MCALLISTER, 1952)

\begin{tabular}{ccc}
\hline \hline Unit & Thickness (ft) & Thickness (m) \\
\hline 5 & 35 & 10.7 \\
4 & 335 & 102 \\
3 & 530 & 162 \\
2 & 470 & 143 \\
1 (Lippincott) & 155 & 47.2 \\
\hline
\end{tabular}

Unit 3 of the Lost Burro Formation is $162 \mathrm{~m} \mathrm{(530} \mathrm{ft)} \mathrm{in} \mathrm{thickness} \mathrm{at} \mathrm{the} \mathrm{type}$ locality (McAllister, 1952) and is composed of alternating bands of dark and light carbonate with some sandstone layers. These carbonate bands are conspicuous in outcrop due to significant color differences (Fig. 4). The dark grey layers can be either limestone or dolomite, though the light grey layers are generally dolomite and the dark layers generally are limestone (McAllister, 1952). 


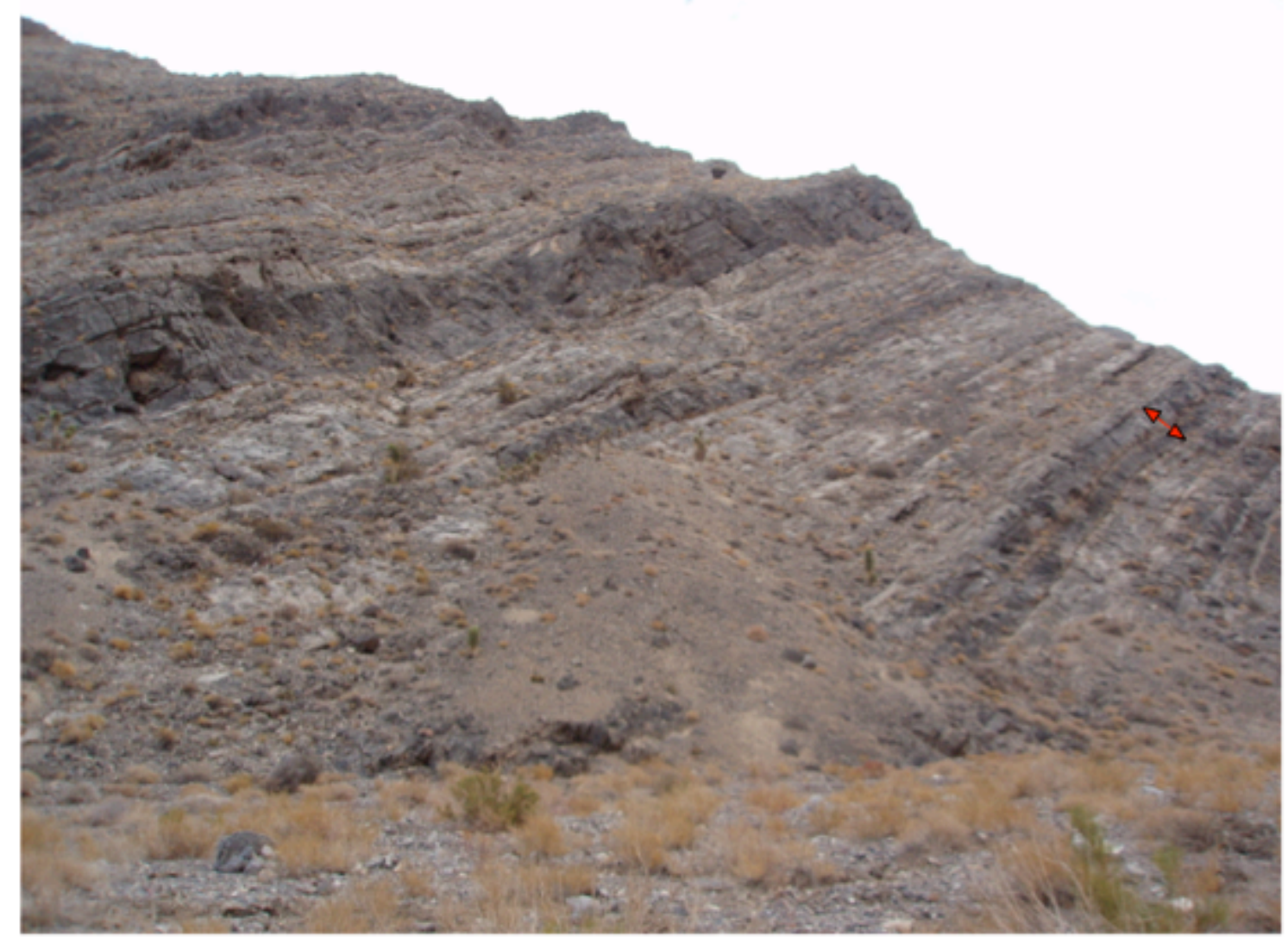

Figure 4. Variations in bed coloration in the Lost Burro Formation on the northeast side of Lost Burro Gap. Prominent dark limestone bed marked by red arrows on middle right is $1.9 \mathrm{~m}$ thick.

The darker layers locally contain white "spaghetti-like" forms, which are identified by McAllister (1952) as the stromatoporoid Amphipora. Figure 5 shows an Amphipora-rich bed. Hemispherical stromatoporoids are also common (Figs. 6, 7). Some colonial rugose corals including "Diphyphyllum" (Fig. 8), the tabulate coral Favosites (Fig. 9), and some solitary rugose corals (Fig. 10, which also shows Amphipora) were found in the dark limestones. Yang et al. (1995) also reported unspecified brachiopods, mollusks, and gastropods in this unit, though none were observed in the field during the course of this study within the measured section. 


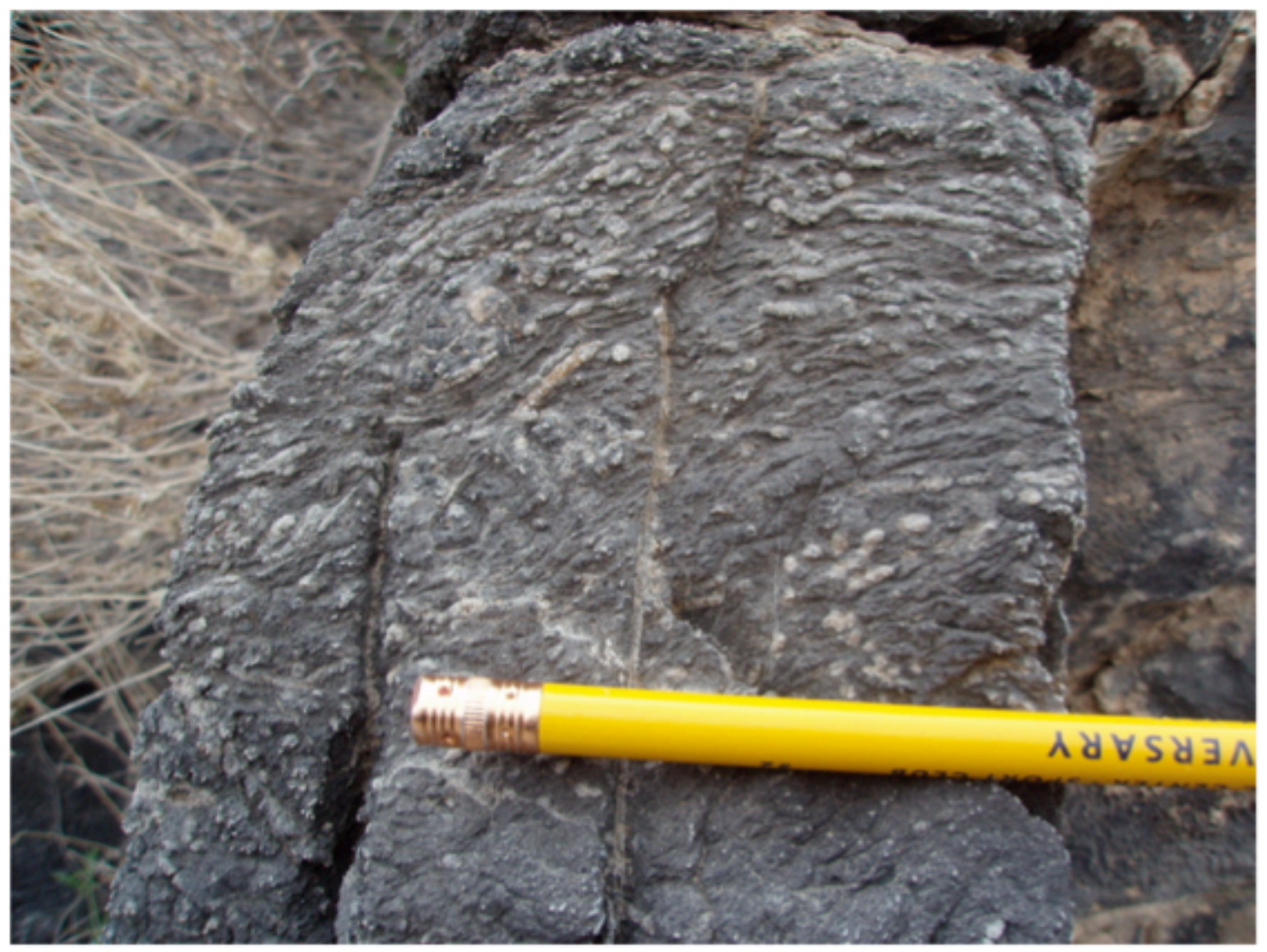

Figure 5. Amphipora, Lost Burro Formation in Lost Burro Gap (pencil ferrule $1.4 \mathrm{~cm}$ long).

Stromatoporoid beds can be several meters in thickness (though none that thick were observed within the section measured for this study), but coral-bearing layers tend to be thinner $(5-40 \mathrm{~cm})$. The fossils suggest that this unit is Middle Devonian in age (McAllister, 1952). 


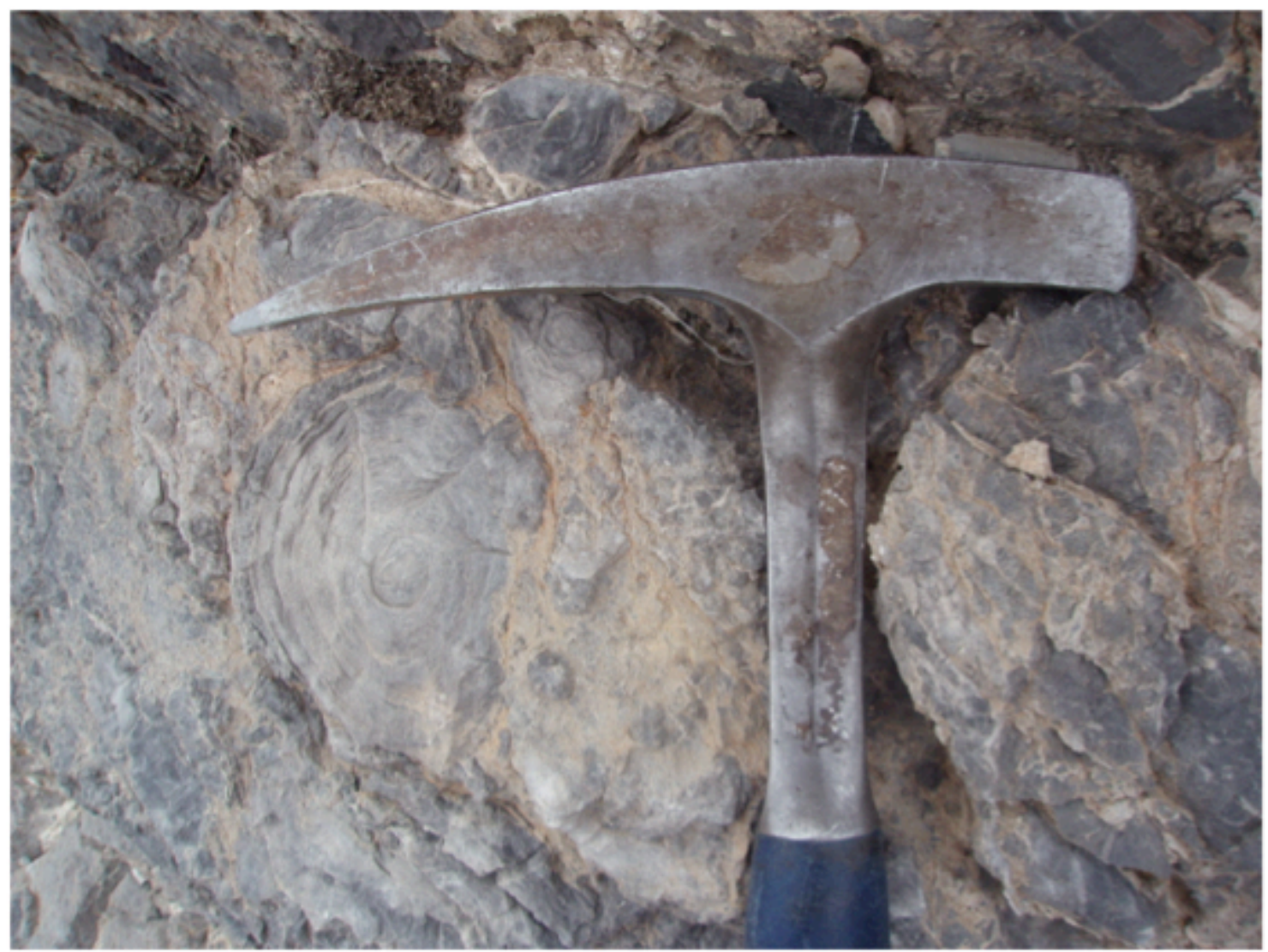

Figure 6. Massive stromatoporoid in Lost Burro Formation (rock hammer head about 18 cm long).

Unit 4 of the Lost Burro Formation is composed of dolomite, with alternating light grey and medium grey layers. The banding in this unit is less pronounced than that in unit 3. It is $102 \mathrm{~m} \mathrm{(335} \mathrm{ft)} \mathrm{in} \mathrm{thickness} \mathrm{at} \mathrm{the} \mathrm{type} \mathrm{locality} \mathrm{(McAllister,} \mathrm{1952).}$

Unit 5 of the Lost Burro Formation, like the Lippincott Member, is a sandy dolomite that is light grey in color. The uppermost layers of this unit contain sandy shale and quartzite beds and tend to weather brown. The brachiopod Cyrtospirifer occurs in the upper layers, as do bryozoans and "other corals" (McAllister, 1952). 


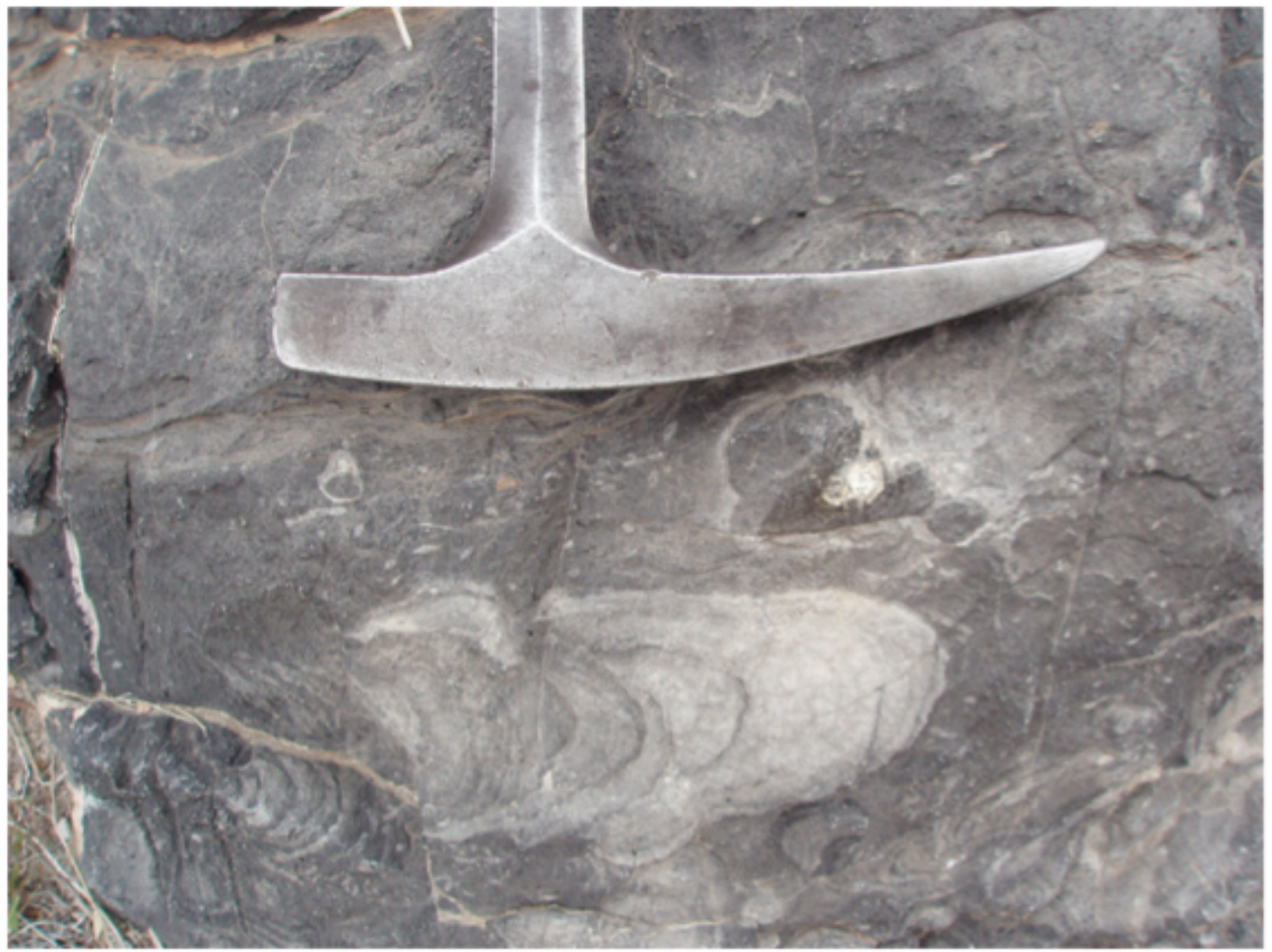

Figure 7. Massive stromatoporoids in Lost Burro Formation (rock hammer head about 18 cm long).

Conodonts have also been found in the uppermost unit of the Lost Burro Formation (Youngquist and Heinrich, 1966; Stevens et al., 1996). On the basis of the fossil evidence (both conodont and brachiopod), the upper Lost Burro Formation was determined to belong to the Cassadaga Stage of the Late Devonian (Youngquist and Heinrich, 1966; Stevens et al., 1996). The Cassadaga Stage falls within the Famennian faunal zone, which ranges in age from 374.5 to $359.2 \mathrm{Ma}$ (Thorez et al., 2006). At the

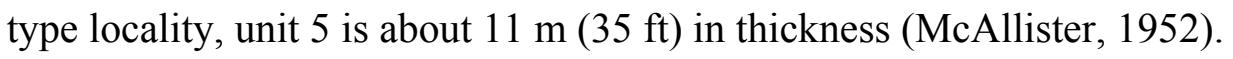




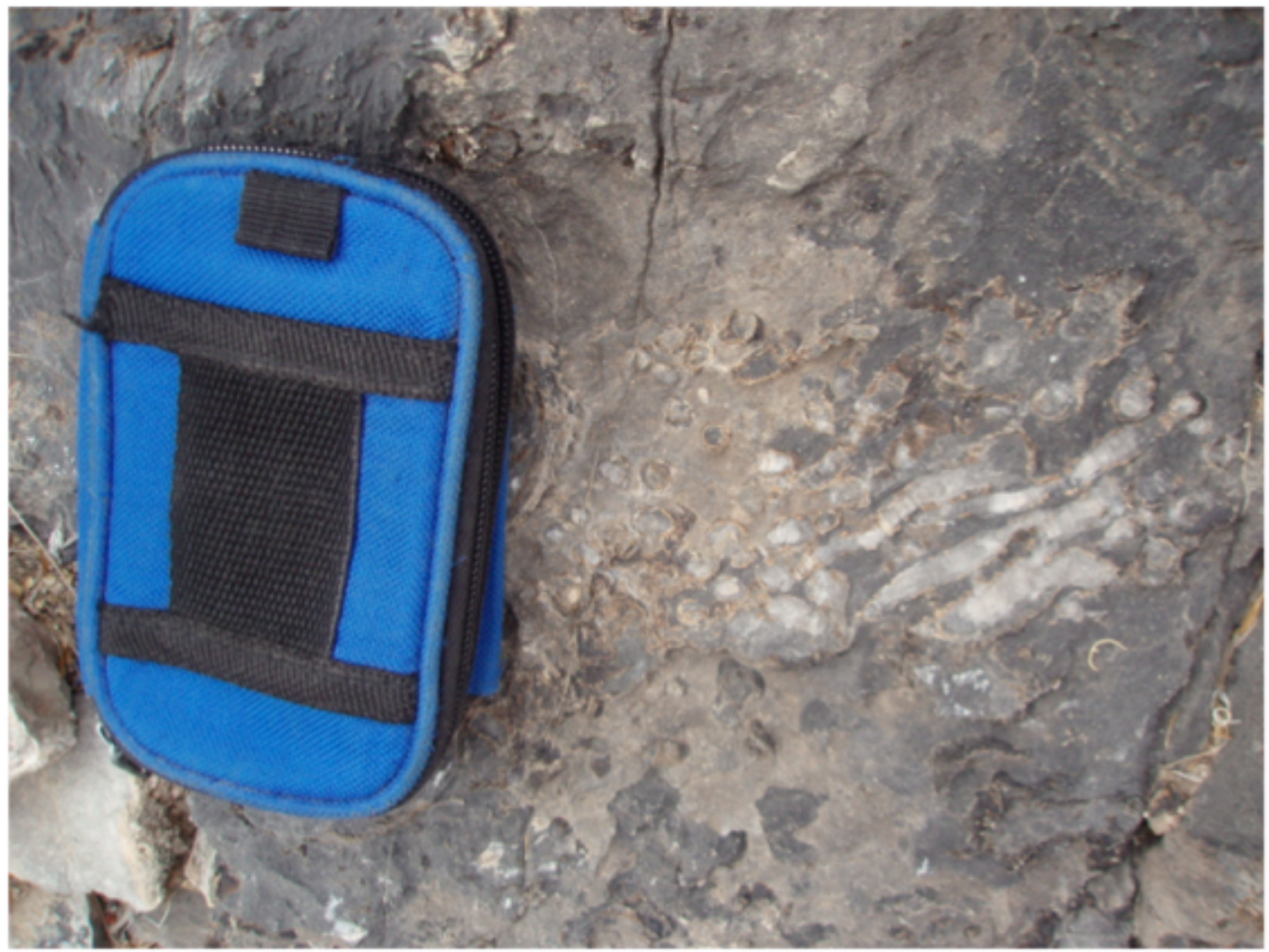

Figure 8. The rugose coral Diphyphyllum, Lost Burro Formation (camera case $12.5 \mathrm{~cm}$ tall).

Figure 11 shows units 4 and 5, displaying the muted banding in unit 4 and the characteristic colors of unit 5 .

The focus of this study was an interval $9.6 \mathrm{~m}$ thick within unit 3 of the Lost Burro Formation. This study was initiated to provide more detail on a part of the 186-m-thick measured section of the Lost Burro Formation from which Yang et al. (1995) made only 27 thin sections. In order to gain detailed observations of the Lost Burro Formation, the present study was restricted to the 9.6-m interval measured at the type locality, from which 57 thin sections were made. 


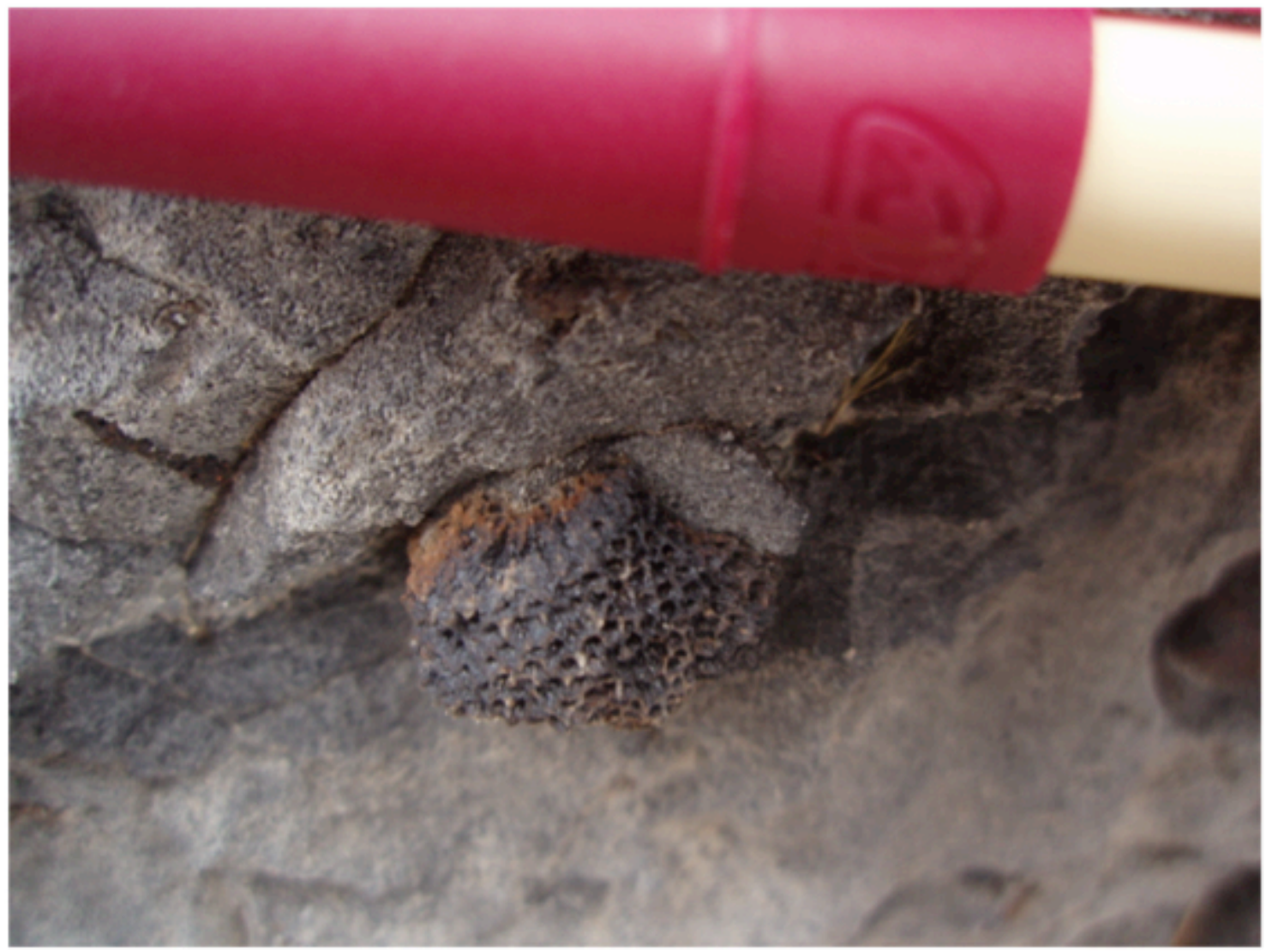

Figure 9. Favositid tabulate coral, Lost Burro Formation (pen cap $0.8 \mathrm{~cm}$ from rightmost cap edge to cap ridge at left of embossed pen logo).

\section{Paleoenvironmental Indicators}

Fossils observed in the field and microfossils observed during petrographic work can be used to make interpretations of paleoenvironment. In this study, the aspect of paleoenvironment that was of most interest was water depth.

The stromatoporoid genus Amphipora was observed in many of the layers within the measured section. 


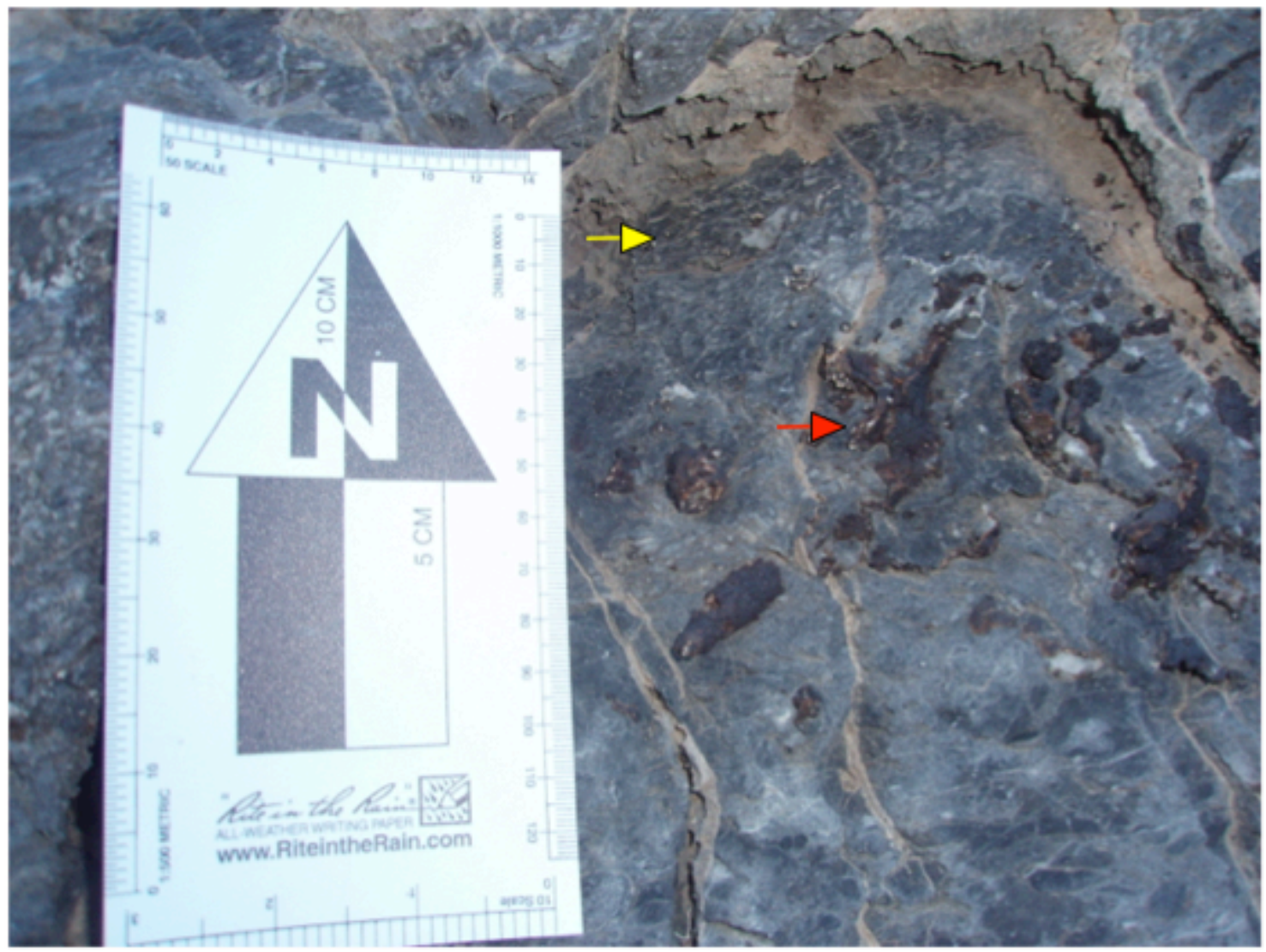

Figure 10. Rugose corals (red arrow) and Amphipora (yellow arrow) in Lost Burro Formation (full black and white arrow is $10 \mathrm{~cm}$ tall).

Some previous workers (Kyle, 1981; Galli, 1985; Elrick, 1995; Witzke and Bunker, 1997; Hladil, 2007; Jannusch, 2008; Schneider et al., 2013) have interpreted Amphipora to indicate lagoonal environments, and that interpretation is used in this study.

Hemispherical stromatoporoids were found in the measured section. Stromatoporoids were typically photic-zone reef builders during the Silurian and Devonian (Benton and Harper, 2009). The samples observed in the measured section were used to interpret a normal marine, subtidal environment within the photic zone. 


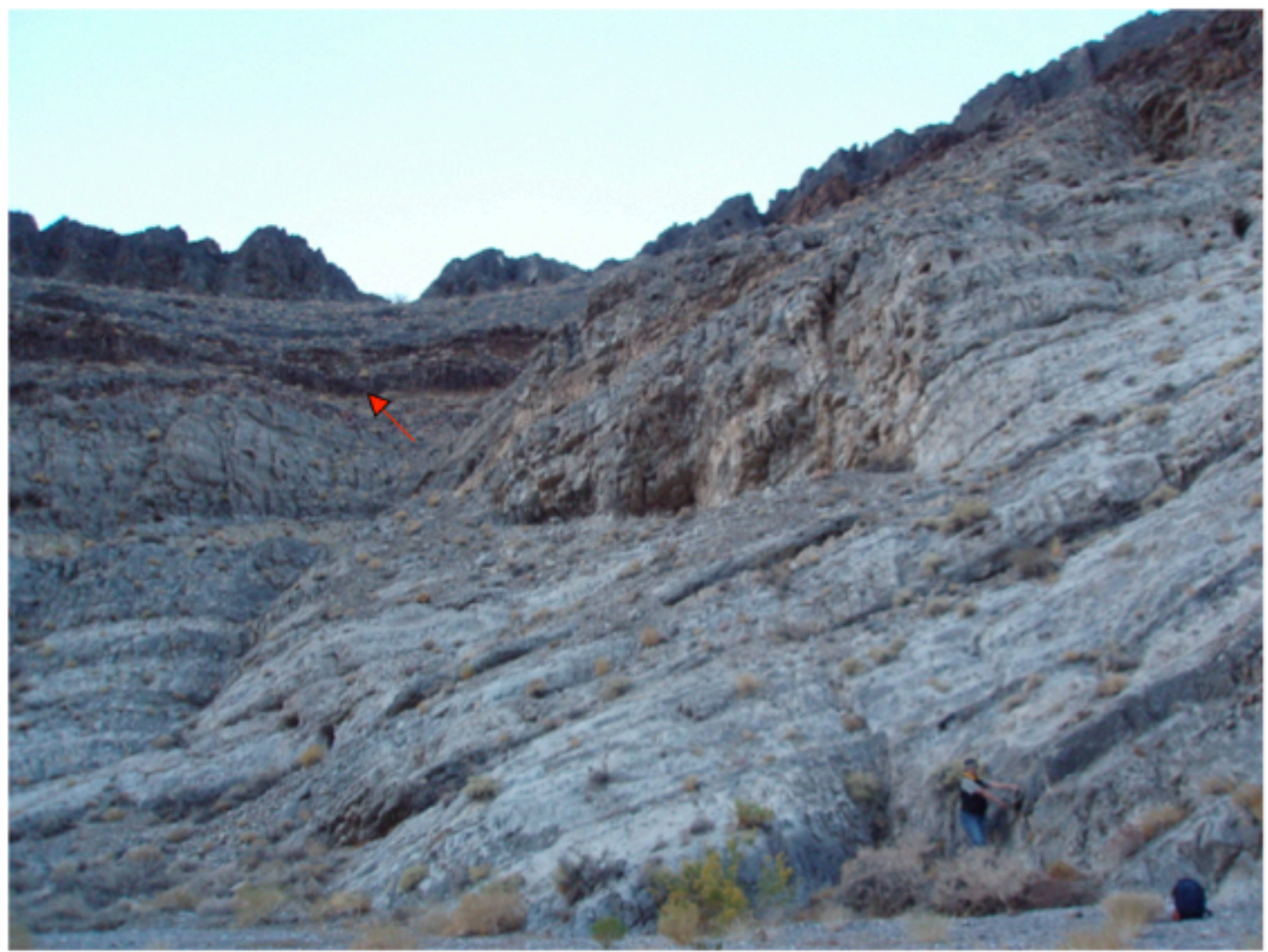

Figure 11. Units 4 and 5, Lost Burro Formation, and Tin Mountain Limestone, northeast side of Lost Burro Gap (field assistant in lower right is $172 \mathrm{~cm}$ tall). Contact is at base of dark brown limestone layer (red arrow).

Tentaculites have been tentatively identified in the samples from this study, based on their tapering acicular structure of connected chambers, an approximate chamber diameter of $0.1 \mathrm{~mm}$ and a fossil length ranging from 0.22-0.4 $\mathrm{mm}$. Given that this designation is tentative, it is so indicated by a (?) preceding each reference to these organisms within the Lost Burro Gap thin sections. In general, (?) Tentaculites have been found in rocks representing a wide range of environments, from oxygen-depleted, deepmarine environments to fully oxygenated marine environments (Hajlasz, 1974) to 
peritidal hardgrounds below ribbon limestones (Cornell et al., 2003). As such, these fossils were not used as paleoenvironmental indicators in this study.

Rugose corals were observed in the measured section, including Diphyphyllum. Rugose corals were some of the Devonian reef builders and required normal marine salinity (Benton and Harper, 2009). These fossils were used (except where noted) to interpret a shallow subtidal environment.

Crinoid fragments were also found in three thin sections, in some cases in low abundance. They were found in thin sections with characteristics that were indicative of subtidal environments. Despite their fractured nature, they were still used as indicators of normal marine, subtidal environments because these organisms are found in environments with normal salinity (Benton and Harper, 2009). An unidentified echinoderm disc fragment was found in one thin section (LBG16B), but the dominant features within that thin section were indicative of intertidal environments. In that case, the fragment was inferred to have washed in.

Brachiopods are rare within the measured section, and those observed were interpreted in conjunction with the crinoids to represent normal marine, subtidal conditions.

Ostracods were observed in several thin sections from the measured section, though not in abundance. Ostracods are minor in abundance and were not considered useful for environmental interpretation in these rocks. 


\section{Overview of Carbonate Sequence Stratigraphy}

Sequence stratigraphy is a method used to put sedimentologic units into a broader context - to take individual units and combine them in packages that can be recognized over broader geographic areas and in stratigraphic associations with other rocks. Using this method, individual facies can be related to one another and to the collection of facies within a unit or formation as a whole. This is often done using seismic data, well-log data, core data, and information gathered at the outcrop (Catuneanu et al., 2009).

Carbonate sequence stratigraphy applies these principles to relate carbonate beds and facies to one another and to the sea-level changes that play a part in their formation. Beds can be combined to form a parasequence. A parasequence is defined as "a relatively conformable succession of genetically related beds or bed sets bounded by marine flooding surfaces and their correlative surfaces" (Van Wagoner, 1985). Parasequences are then combined to form sequences that can be used to examine trends in deposition over a longer time frame than a single parasequence. A sequence was originally defined as "a relatively conformable succession of genetically related strata bounded by unconformities or their correlative conformities" (Mitchum, 1977).

Over time, parasequences have come to include the concept that they are generally shallowing-upward (Van Wagoner et al., 1988; Holland, 2008). This concept has drawn criticism in that it does not adequately account for parasequences that contain deepening-upward components (Arnott, 1995; Spence and Tucker, 2007), and it can cause more confusion due to conflicting usage where another term may be more appropriate (Zecchin, 2010). 
To answer this problem, Spence and Tucker (2007) proposed that a parasequence could be defined as "a regionally significant meter-scale sedimentary package characterized by a succession of facies that may shallow-up, deepen-up then shallow-up, aggrade, or reflect constant water depth" (Spence and Tucker, 2007, p.807). While this definition does mention water depth, the authors also use marine flooding surfaces to define parasequence boundaries. Although a new wording for the standard definition was proposed, no alternate definition has been broadly accepted by the community (Zecchin, 2010).

Many studies of peritidal carbonate parasequences looking at the stacking patterns within peritidal deposits have been conducted (e.g., Montanez and Osleger, 1993; Elrick, 1995). These authors examined platform carbonates from the Middle to Upper Cambrian and Devonian, respectively, and tried to categorize changes in bed characteristics in terms of stacking patterns. They also assigned a type to each parasequence (peritidal or subtidal) based on the dominance of those kinds of environments within that parasequence. The type of parasequence and parasequence thickness were considered for each parasequence within a measured section (Montanez and Osleger, 1993). Yang et al. (1995) used a similar approach to evaluate the changes in bed lithology and thickness at Lost Burro Gap to determine the causes of those changes.

\section{Paleoenvironment and Depth Controls}

Yang et al. (1995) studied the middle and upper units of the Lost Burro Formation in order to investigate the controls on water depth during the Devonian. Those authors 
concluded that the controls were allogenic in nature, dominated by Milankovitch cycles (Yang et al., 1995). Their study utilized spectral and gamma analysis of field measurements. The middle and upper units of the Lost Burro Formation were systematically classified into seven lithologies, and these were classified as either intertidal, subtidal or supratidal environments based upon field examination and petrographic studies. A depositional cycle was defined as any group of beds showing transitions from transgressive intertidal to transgressive subtidal and then regressive subtidal, to regressive intertidal, to supratidal conditions. If only intertidal and supratidal environments were found, the cycle top was set at the boundary between regressive and transgressive intertidal facies. If this boundary was indiscernible, the cycle top was set at the midpoint of the combined intertidal beds (Yang et al., 1995). Yang et al. (1995) defined 54 depositional cycles within their 186-m measured section. The individual bed thicknesses were measured and used to calculate cycle duration (period) and the ratio of time to unit thickness (gamma). The frequency of period values was used to plot power density curves for the uncorrected (uniformly stretched) and corrected (nonuniformly stretched) gamma values. These values were subjected to statistical analysis in order to determine if the periodicity of the cycles matched any of the Milankovitch cycle periodicities (Yang et al., 1995).

The analyses were run twice, first assuming that all environments had the same time to thickness ratio (gamma uncorrected), and a second time using different values of time to thickness ratios (gamma corrected series). The corrected values were obtained by separating cycles into groups with different cycle periods, applying least-squares 
inversion to obtain the gamma values for each group, and then normalizing the values until they had the same units (gamma time/thickness). Once they had the same units, the normalized gamma values were used to generate a gamma time series from facies thicknesses, and spectral analyses were run on these data. This "corrected" method allows for non-uniform sedimentation rates, and was considered more realistic than using an average value of gamma for all environments. The "corrected" method was also necessary, because using the first analysis (gamma uncorrected) showed that either not all of the 54 depositional cycles measured had the same duration, or that the depositional rates were not constant. With some finessing of the data, three distinct data groups were established within the 54 cycles (each having different cycle durations), and better statistical resolution was achieved. It was concluded that each sub-environment had approximately constant sediment accumulation rates in this part of the Devonian. The calculated accumulation rate for subtidal environments was $280 \mathrm{~mm} / \mathrm{ky}$. The accumulation rate for intertidal environments ranged from $160-190 \mathrm{~mm} / \mathrm{ky}$. The accumulation rate for supratidal environments was $60-70 \mathrm{~mm} / \mathrm{ky}$. These accumulation rates include post-depositional effects, such as erosion, compaction, and stylolitization (Yang et al., 1995).

These accumulation values did not match the average values that Yang et al. (1995) calculated based on measured section thickness and index fossil-derived age dating (27-31.2 mm/ky), and the statistical analysis did not account for non-depositional hiatuses. The gamma ratio of time/thickness was also assumed to be uniform within each of the three data groups. Ultimately, the spectral peaks plotted using the recalculated data 
matched Milankovitch peaks for the obliquity and precession index cycles (Yang et al., 1995).

The present study was based on a much smaller measured section than that of Yang et al. (1995) and lacks sufficient stratigraphic range to comment with statistical significance on allogenic vs. autogenic forcing. Instead, a simpler calculation of the shoaling index used by Wilkinson et al. (1997) was used to determine the pattern, if any, of paleoenvironmental shallowing and deepening within the measured section. The petrographic data were used to examine the layers within the measured section in greater detail, to gain greater insight into the preserved paleoenvironments and also thereby to increase the number of sub-environments used in the shoaling index calculation.

Wilkinson et al. (1996) conducted a statistical analysis of eight previous studies of cyclicity in North American rocks ranging from Early Proterozoic to Pennsylvanian age. One of the previous studies examined was the work of Yang et al. (1995) on the Lost Burro Formation.

Wilkinson et al. (1996) found that the stated sequential deposition of the three environments (subtidal, intertidal, supratidal) depended upon the perception of shallowing-upward cycles. These authors also observed that classification of each layer within the units was done assuming each cycle terminated in a supratidal environment (the cycle top), and that units above this arbitrary top layer were subtidal by definition. If the layer at the top did not fit the required characteristics, that layer was classified as intertidal and a gap was inserted into the order to represent the missing supratidal layer (Wilkinson et al., 1996). The use of diagnostic lithologies showing subaerial exposure as 
the "cycle tops" was thought to skew classification of the next layer deposited.

Lithologies overlying cycle tops, no matter what their characteristics, thus become substitutable with one another as "cycle bases." This reduces the number of environments to only two or three, blurring the sequential depositional pattern (if any) through lumping. This methodology is also dependent on the perception of a pattern, making reproduction of the results difficult and subjective (Wilkinson et al., 1996).

Wilkinson et al. (1996) concluded that the measured cycle thicknesses and frequencies from the Lost Burro Formation revealed stochastic results rather than meterscale cyclicity. With increasing cycle thickness, there was an exponential decrease in number of cycles. Statistical variation in bed thicknesses (as compared to mean bed thickness) showed a pattern similar to that of randomly generated bed thicknesses, a result that was driven by the low number of environments (three). Actual stratal order and associations of lithofacies were inferred to be more influenced by localized changes in eustatic sea level, sediment supply, and energy of environment. Wilkinson et al. (1996) thus concluded that allogenic extrabasinal controls would produce a higher degree of order than is displayed in the Lost Burro Formation, which indicates that Milankovitch cycle-based forcings are not dominant.

Wilkinson et al. (1996) did not strictly invalidate the methods used by Yang et al. (1995), but they indicated the importance of the documentation of methodology and validation of assumptions made. Wilkinson et al. (1996) further emphasized the importance of determining that cycles were not randomly generated before interpretations of the stacking origin are made, because correlation of environmental changes in the 
rocks does not necessarily indicate causation by Milankovitch cycles (Wilkinson et al., 1996).

The assertions of Wilkinson et al. (1996) provide the foundation from which the present investigation originated. This study was conducted in order to determine whether a pattern of paleoenvironments was preserved within unit 3 of the Lost Burro Formation, as asserted by Yang et al. (1995), particularly if more than three sub-environments were considered. 


\section{METHODS}

This study was based on field observations and the examination of thin sections of carbonates and calcareous sandstones sampled from the Lost Burro Gap. In March and October 2010, visits were made to the area for the purposes of investigation, sampling, and fieldwork. A follow-up visit was made in November 2012.

The measured section is located at $\mathrm{N} 36.74577^{\circ}, \mathrm{W} 117.51772^{\circ}$, on the northeast side of Lost Burro Gap. This area was selected due to its banded appearance, suggesting alternating environments of deposition and relative lack of alteration. Figure 12 shows the entirety of the measured section on the northeast side of the outcrop.

The first visit was used to investigate continuity, accessibility, and quality of exposures in Death Valley National Park. The second visit focused on Lost Burro Gap. Sampling was done at this time. The stratigraphic section was measured using a Jacob's staff and GPS unit to mark the location of the measured section base. The section's structures, lithologies, colors, textures, and fossil assemblages were carefully described in the field and unit thicknesses were measured and recorded. Sedimentary structures and lateral changes within each unit were also noted. The chief purpose of taking these measurements and making these observations was to characterize the rocks and to recognize and assign parasequence boundaries (if present) in the field. The measured section was used to organize the samples taken and put them into geologic context. Photographs of the sampled outcrops were used to further support the petrographic analysis. 


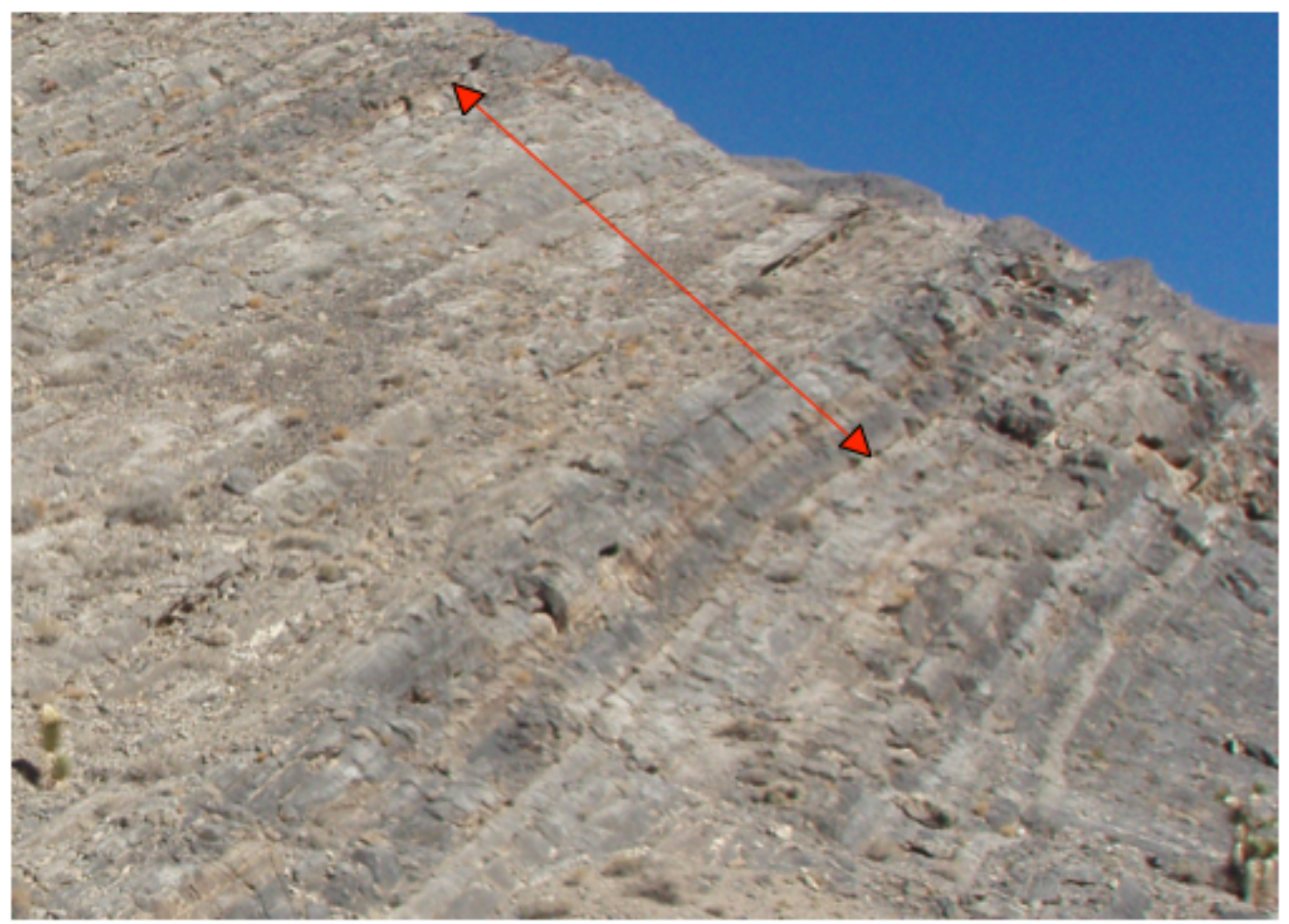

Figure 12. View of measured section (red arrows), northeast side of Lost Burro Gap. Measured section is $9.6 \mathrm{~m}$ thick.

From within the section, 69 samples were brought back for petrographic and paleontologic analysis. Multiple samples were collected from each unit recorded within the measured stratigraphic section. These samples were used to produce 57 thin sections that were examined for presence of microfossils and microtextures. If the sample covered a sufficient thickness, some of these samples were made into more than one thin section. The author made 43 of the thin sections at San Jose State University, and 14 were sent for commercial preparation. The allochems present, which consist of the microfossil or carbonate grains making up the framework within each thin section, were identified and recorded. The combination of allochems and character of the host rock 
was used to classify each thin section according to either Wilson's Standard Microfacies (Wilson, 1975) or the modifications of Wilson's SMFs as outlined by Flügel (2004). The rocks also were named using the classification schemes of Dunham (1962) and Folk (1980). The initial examination of the Lost Burro Gap thin sections was done out of stratigraphic order, in order to prevent bias toward any predetermined pattern.

Some samples were also dissolved in acetic acid for the recovery of conodonts. No intact conodonts were found.

A third visit to Lost Burro Gap, conducted in November 2012, was completed in order to obtain more detailed outcrop-scale observations of sequences and sequence boundaries. 


\section{RESULTS}

\section{Field Observations}

\section{Layers}

The measured section at Lost Burro Gap (Fig. 12) spans 21 distinct layers, shown in Appendix 1 and Figure 13 and described below. Figure 13 shows the measured section, displaying the locations of the samples taken from these beds and including a description of both the outcrop-scale fossils observed in the field and microfossils and mineral grains observed under the microscope. The appendix also contains a table with the measured section descriptions, layer thicknesses, and classifications using the criteria of Dunham (1962).

The base of the measured section was placed immediately above a sandstone bed that was laterally continuous at the base of the outcrop.

Layer 1. This layer is a 75-cm-thick bed of dark-gray limestone. There are fewer than $10 \%$ Amphipora visible at the outcrop, so field classification of the layer makes it appear to be a mudstone by Dunham's (1962) classification system (later thin section study showed it to be a wackestone). The Amphipora that are present are small (1-3 mm in length, 1-2 $\mathrm{mm}$ in diameter) and are localized at the base of the bed. The remainder of the 75-cm-thick bed is unfossiliferous. The limestone has a sharp boundary with the underlying sandstone.

Layer 2. Overlying Layer 1 is a sandstone bed, measuring $5 \mathrm{~cm}$ thick at its thickest point and tapering to $\sim 0.5 \mathrm{~cm}$ at its thinnest. Figure 14 shows this lenticular bed. 


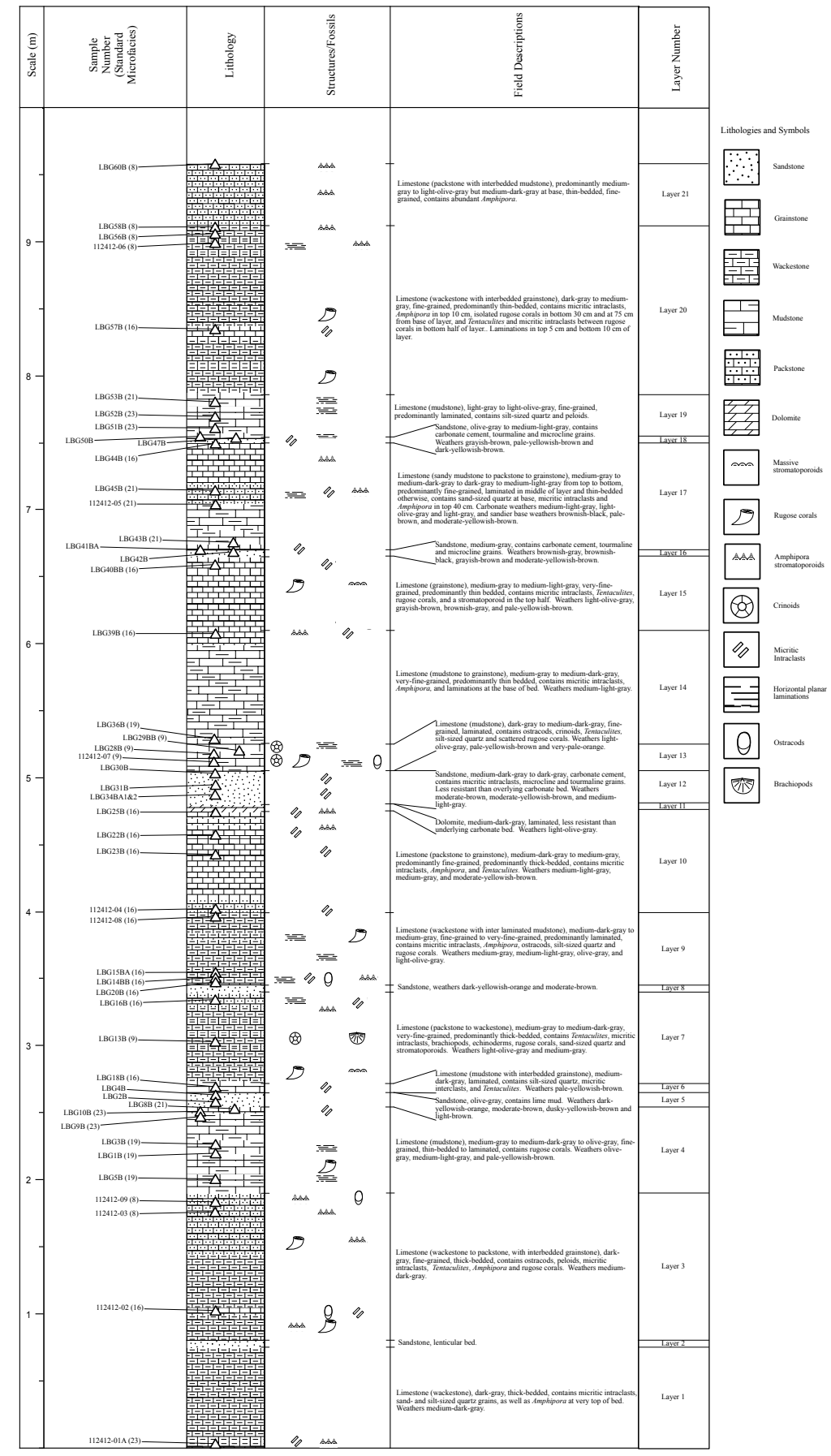

Figure 13. Measured section with sample locations, field observations, and some features observed in thin section. 


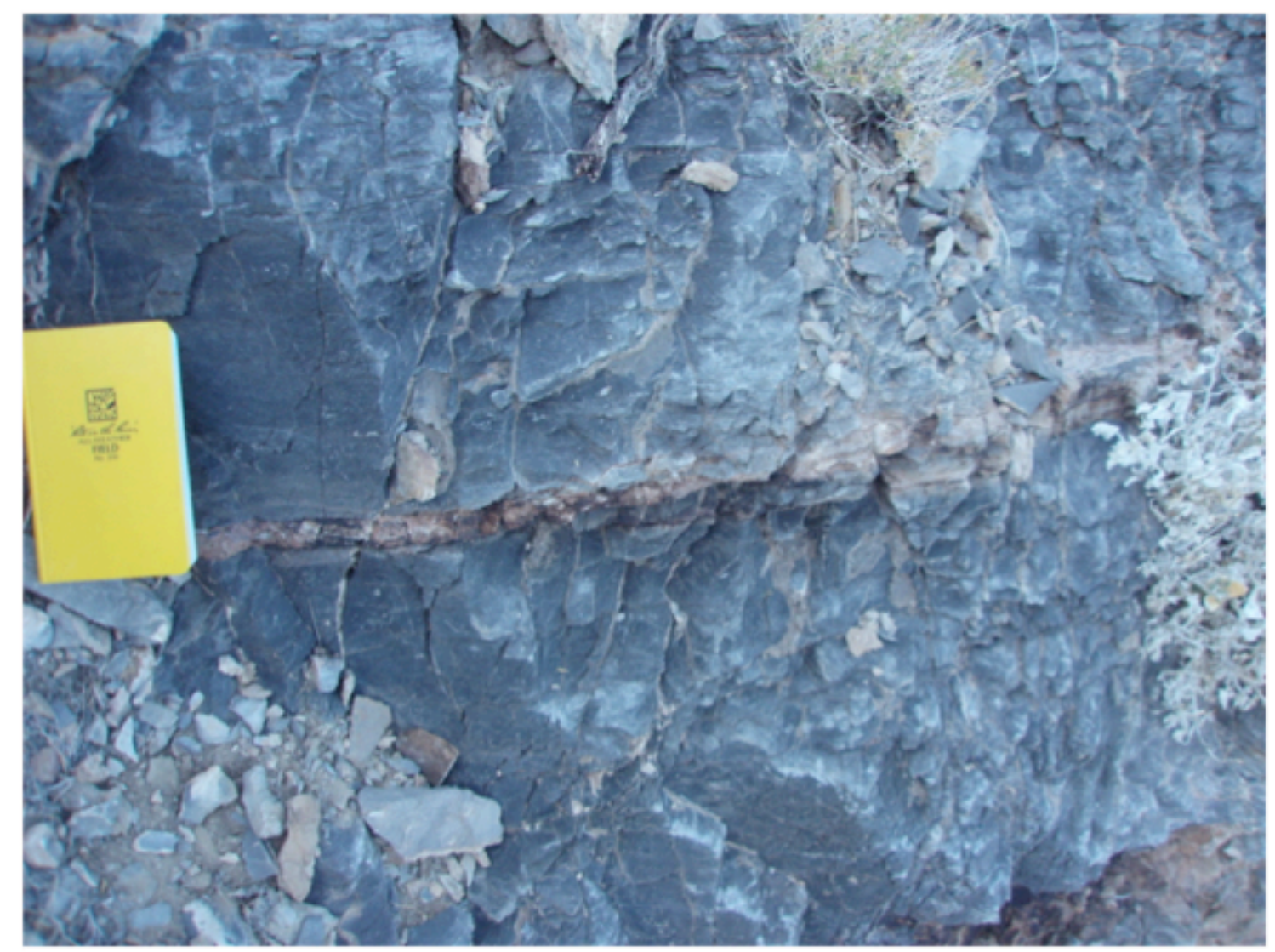

Figure 14. Discontinuous sandstone layer (Layer 2). Field notebook is $19 \mathrm{~cm}$ tall. Base of layer is marked by base of field notebook.

It has a sharp boundary with the underlying $75-\mathrm{cm}$ limestone bed. On either side of the thickest point shown in the figure, the bed tapers to sandy stringers.

Layer 3. Overlying Layer 2 is a 110-cm-thick, dark-gray limestone bed with scattered rugose corals at the base. The corals are present throughout the lower $70 \mathrm{~cm}$, occurring in isolated lenses. In the next $15 \mathrm{~cm}$ up-section in the bed, Amphipora is also present with the corals. This 15 -cm-thick portion in the bed shows the highest concentration of corals; approximately $10 \%$ of allochems present within that $15 \mathrm{~cm}$ are corals with the remainder being Amphipora. The corals are jumbled and not in growth 
position. Figure 10 shows these fossils and their respective densities. The overall percentage of allochems within that 15 -cm-thick section is estimated to be $50 \%$. In the top $25 \mathrm{~cm}$ of the dark-gray limestone, Amphipora is the sole visible fossil in the field, and composes $\sim 50 \%$ of the rock. The 110 -cm-thick limestone has a sharp boundary with the underlying 5-cm tapering sandstone.

Layer 4. Overlying Layer 3 is a $65-\mathrm{cm}$-thick interval of medium-gray to mediumdark-gray to olive-gray limestone. It is mostly thin bedded, though two bands $(5 \mathrm{~cm}$ near the base of the bed, and $10 \mathrm{~cm}$ in the middle of the bed) are laminated. Some very small, black-weathering corals are preserved in the limestone $15 \mathrm{~cm}$ from the base of the bed. The bed is capped by laminations of reddish material running through the limestone. The 65-cm-thick bed has a sharp boundary with the underlying limestone.

Layer 5. Overlying Layer 4 is a $10-\mathrm{cm}$-thick sandstone bed. The weathering colors for this bed range from dark yellowish orange to moderate brown, dusky yellowish brown, and light brown. The sandstone has a sharp boundary with the underlying limestone.

Layer 6. Overlying Layer 5 is a 5-cm-thick, medium-dark-gray limestone. It weathers pale yellowish brown and is unfossiliferous. This bed has a gradational transition with the underlying sandstone, with silt-sized quartz grains in decreasing concentration from the base of the limestone to the top.

Layer 7. Overlying Layer 6 is a 70-cm-thick interval of medium-gray to mediumdark-gray limestone. It weathers medium-gray to light-olive-gray. Within the bottom 60 $\mathrm{cm}$ of the bed, isolated black stromatoporoids are present. These fossils range from 10 to 
$20 \mathrm{~cm}$ in size. Isolated horn corals are also present in the bottom $10 \mathrm{~cm}$. The top $10 \mathrm{~cm}$ of the bed include isolated Amphipora. The fossil content of the entire bed thickness is greater than $10 \%$. The top $10 \mathrm{~cm}$ of the $70-\mathrm{cm}$-thick bed is laminated, but otherwise this limestone is thick-bedded. The limestone has a gradational transition with the underlying 5-cm-thick limestone bed.

Layer 8. Overlying Layer 7 is a 5 -cm-thick sandstone bed. The contact with the underlying limestone is largely covered.

Layer 9. Overlying Layer 8 is a $55-\mathrm{cm}$ interval of medium-gray to medium-darkgray limestone (colors change from base of bed to top of bed). The bed is coarse-grained at the base and fines upward. Isolated rugose corals are present in the middle of the layer. Otherwise, it appears unfossiliferous. Amphipora were apparent in thin section. The bottom $40 \mathrm{~cm}$ of this bed is laminated, and the top $15 \mathrm{~cm}$ are thin-bedded. The contact with the underlying sandstone is largely covered.

Layer 10. Overlying Layer 9 is an 80 -cm-thick limestone bed that weathers medium gray to medium light gray with some moderate yellowish brown weathering in lesser amounts. When broken to expose a fresh surface, this limestone is medium-darkgray to medium-gray. In the field, the bed appears to be fine-grained, unfossiliferous, and thick-bedded. Thin section study showed that Amphipora and Tentaculites are present. In the field it appears coarsely crystalline, almost sugary in texture. The outcrop is highly fractured. The 80 -cm-thick limestone bed has a sharp contact with the underlying limestone. 
Layer 11. A 5-cm-thick cap of light-olive-gray-weathering dolomite overlies Layer 10, though the contact between the two is covered. As with the underlying limestone, the fresh surfaces are medium dark gray. This layer is apparent in the field due to preferential weathering and decreased reaction of the carbonate with acid. Some laminations are present.

Layer 12. Overlying Layer 11 is a 25 -cm-thick sandstone bed. It is dark gray to medium dark gray, but the weathered colors (moderate-yellowish-brown, moderatebrown, medium-light-gray) are more apparent in the field. It also is more deeply weathered than the nearby limestones. It has a sharp boundary with the underlying dolomite.

Layer 13. Overlying Layer 12 is a 15 -cm-thick, dark-gray to medium-dark-gray limestone. The limestone is laminated. There are sparse rugose corals near the middle of the bed, and what were interpreted in the field as isolated Amphipora near the top of the bed. In thin section, these were later identified as (?) Tentaculites. It has a sharp boundary with the underlying sandstone.

Layer 14. Overlying Layer 13 is an 85-cm-thick interval of medium-dark-gray to medium-gray limestone. It is close in color to the underlying limestone and is also laminated in the bottom $10 \mathrm{~cm}$, so there is a gradational transition between the two beds. Above this bottom $10 \mathrm{~cm}$, the limestone is thin-bedded and appears coarsely crystalline, nearly sugary. In thin section, Amphipora were identified. This layer weathers medium light gray. 
Layer 15. Overlying Layer 14 is a 60 -cm-thick interval of medium-gray limestone. It is very close in color to the underlying limestone and is differentiated from the underlying bed by the fossil assemblage present. Appearing in the top $40 \mathrm{~cm}$ of the bed are scattered rugose corals and a lone, faintly visible stromatoporoid. Sparse (?) Tentaculites are present in the top $10 \mathrm{~cm}$ of the bed. The limestone is thin-bedded and has a 'sugary' appearance that is similar to the underlying limestone. This bed has mottled weathering, ranging in color from light olive gray and grayish brown to brownish gray and pale yellowish brown. It has a gradational boundary with the underlying limestone.

Layer 16. Overlying Layer 15 is a 5 -cm-thick sandstone bed that weathers brownish-gray to brownish-black with lesser amounts of grayish-brown and moderateyellowish-brown. It has a sharp, wavy boundary with the underlying limestone.

Layer 17. Overlying Layer 16 is an 80 -cm-thick limestone bed that ranges in weathered color from medium-light-gray (at the base) to light-gray / light-olive-gray (in the middle) to light-olive-gray (top of bed). The bottom $15 \mathrm{~cm}$ of the bed includes scattered sand grains. The sandier portion of the bed weathers brownish-black, palebrown, and moderate-yellowish-brown. The middle $20 \mathrm{~cm}$ of the bed are laminated. Amphipora is present in the upper $30 \mathrm{~cm}$ and is the only fossil visible in outcrop. The boundary with the underlying sandstone is gradational.

Layer 18. Overlying Layer 17 is a 3 -cm-thick sandstone bed, weathering pale yellowish brown to dark yellowish brown. The contact with the underlying limestone bed is wavy but sharp. 
Layer 19. Overlying Layer 18 is a 25 -cm-thick interval of light-olive-gray to light-gray limestone. The bed is laminated at bottom and top, though the middle $10 \mathrm{~cm}$ are not obviously stratified. The contact with the underlying sandstone is gradational.

Layer 20. Overlying Layer 19 is a 125 -cm-thick, fine-grained interval of medium-gray to dark-gray limestone. The $10 \mathrm{~cm}$ at the base of this bed are laminated, as are the $5 \mathrm{~cm}$ at the top of the bed. The remainder of the limestone is thin-bedded. Isolated rugose corals are present in the bottom $30 \mathrm{~cm}$ of the bed, and at $\sim 75 \mathrm{~cm}$ above the base of the bed. Fossils that were interpreted in the field as Amphipora are present in the top $10 \mathrm{~cm}$. The contact with the underlying light-olive-gray limestone is sharp.

Layer 21. Overlying Layer 20 is a 55 -cm-thick medium-gray to light-olive-gray limestone bed. This bed has a gradational boundary with the limestone below, and also contains an abundance of Amphipora (30-45\%). This bed is distinct from the overlying bed due to the absence of those fossils in the overlying carbonate material. The $55-\mathrm{cm}-$ thick limestone is thin-bedded.

Stratigraphically above Layer 21 is more limestone, but it and the overlying rock layers were not sampled or described in detail.

\section{Striped Appearance}

In the field, the Lost Burro Formation is visibly striped in alternating light and dark colors. When samples were brought back to the lab, however, and the Munsell color chart was used to categorize the fresh surfaces, the differences in color between the dark and light layers became much more subtle. In general, when the light carbonates (both limestone and dolomite) are broken to expose a fresh surface, they are medium dark gray 
to medium gray. The dark limestones have a greater variability in weathering color, ranging from olive gray to light olive gray, medium gray, pale yellowish brown, to very pale orange.

The darker layers are mostly ledge forming, whereas the lighter layers are somewhat less resistant. The sandy lenses are easily weathered out, being quite friable. Figure 15 illustrates the variability in rock resistance.

\section{Carbonate Standard Microfacies \\ Criteria for Standard Microfacies Assignments}

Samples were taken for petrographic analysis during measurement of the section. In this way the samples could be tied to larger scale field observations of individual bed lithology, bed texture, and fossil assemblages.

Each thin section was examined and was assigned a Standard Microfacies (SMF) based on Wilson's SMF classification (Wilson, 1975) and Flügel's modifications of those SMFs (Flügel, 2004). Full thin section descriptions can be found in Appendix 2.

Wilson's classifications were based on carbonates formed in warm-water environments within a rimmed carbonate shelf (Flügel, 2004). Flügel extended the definitions to cover a broader range of depositional models (including homoclinal ramps, platforms, etc.). Of the twenty-six possible SMFs for carbonates, six were recognized using Flügel's modified list in samples of unit 3 from the Lost Burro Formation. 


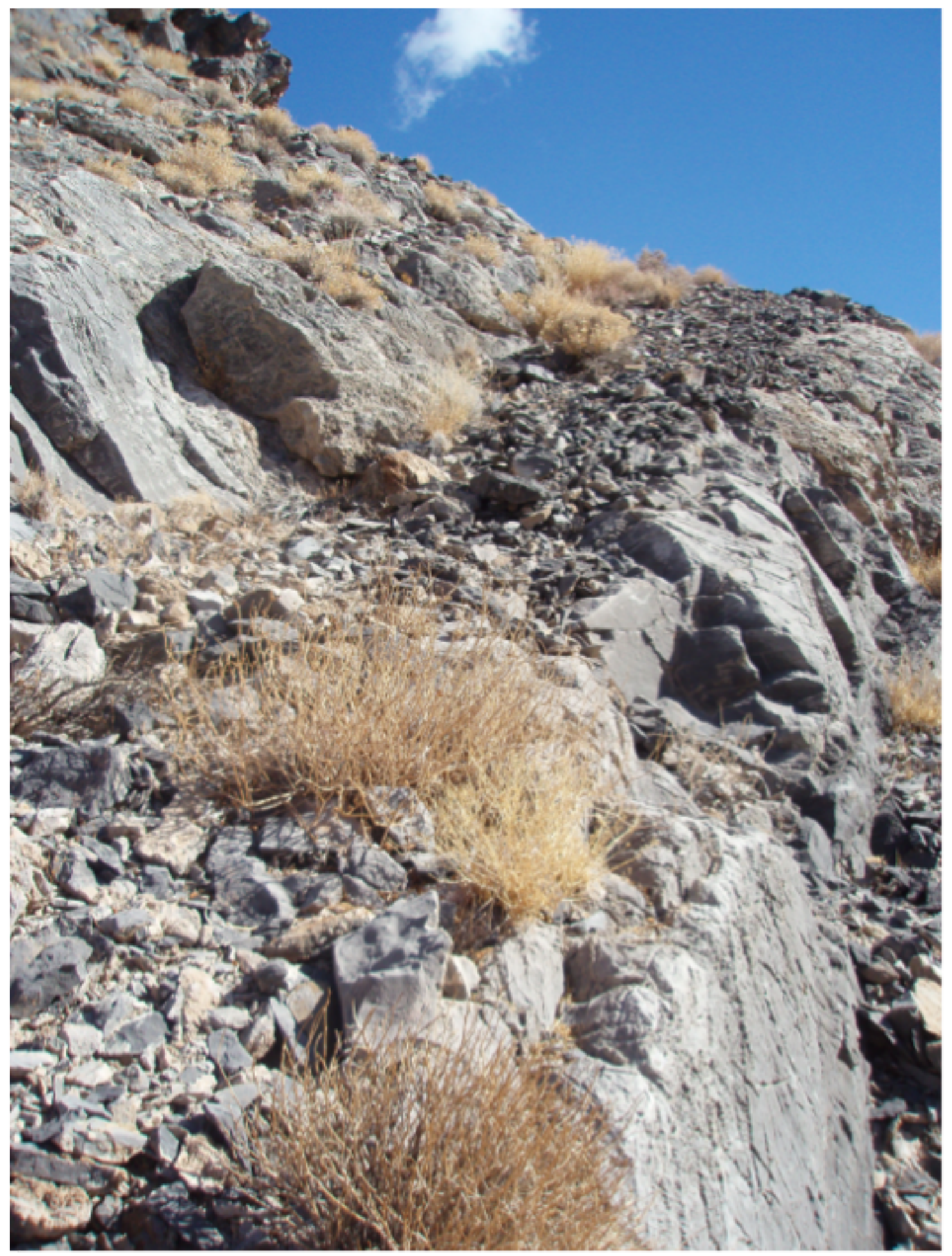

Figure 15. Variations in bed resistance, northeast side of Lost Burro Gap (gray limestone unit underneath weathered layer is $55 \mathrm{~cm}$ thick). 
Table 2 summarizes the classification of the carbonate and sandstone thin sections under the schemes of Dunham (1962), Folk (1980), and Wilson (1975). Also listed are the stratigraphic height of each sample (in $\mathrm{cm}$ above the base of the measured section).

Standard Microfacies 8. This microfacies (shown in Fig. 16) had the highest allochem density of all the microfacies recognized in this study. In thin section, Amphipora with rare ostracods accounted for 30 to $60 \%$ of the rock. The rock can contain up to $10 \%$ peloids. Some rocks assigned to this microfacies were grain-supported, where the grains were fossils and pellets. The allochems were present in micrite.

Under Dunham's (1962) classification scheme, the six Lost Burro Formation SMF 8 samples were packstones (three) and wackestones (three). Under Folk's (1980) scheme, the samples ranged from biomicrite (three) to biopelmicrudite (two, in which peloids were present) and biomicrudite (one).

This microfacies differs from Wilson's definition in that it contains a higher fossil density than "a few scattered bioclasts" (Wilson, 1975). However, Flügel (2004) allows for a much higher allochem density, referring to the microfacies as being "predominantly sessile organisms" (Flügel, 2004). Flügel (2004) also states that a fine-grained micritic matrix with fine-grained bioclasts is common for this SMF. Further, he lists sponges as a characteristic organism for SMF 8, and Amphipora is classified as a sponge (Stearn et al., 1999). A final difference between the microfacies definition and the Lost Burro Gap samples is that the Amphipora are unlikely to have formed in situ, given the broken character of the allochems and the lack of a convincing growth direction. 
TABLE 2. STANDARD MICROFACIES CLASSIFICATIONS OF CARBONATE THIN SECTIONS

\begin{tabular}{|c|c|c|c|c|}
\hline $\begin{array}{l}\text { Height (cm } \\
\text { above base) }\end{array}$ & TS \# & Dunham $^{1}$ & Folk $^{1}$ & Wilson $^{1}$ \\
\hline 962 & LBG60B & Packstone & Biomicrite & 8 \\
\hline 910 & LBG58B & Wackestone & Biomicrite & 8 \\
\hline 907 & LBG56B & Wackestone & Biomicrudite & 8 \\
\hline 903 & $112412-06$ & Wackestone & Biomicrite & 8 \\
\hline 836 & LBG57B & Grainstone & Intrasparite & 16 \\
\hline 782 & LBG53B & Mudstone & Micrite & 21 \\
\hline 772 & LBG52B & Mudstone & Micrite & 23 \\
\hline 760 & LBG51B & Mudstone & Micrite & 23 \\
\hline 757 & LBG50B & -- & Quartzarenite & $\mathrm{ss}^{2}$ \\
\hline 756 & LBG47B & -- & Quartzarenite & ss \\
\hline 751 & LBG44BB & Grainstone & Intrasparite & 16 \\
\hline 714 & LBG45B & Packstone & Intramicrite & 21 \\
\hline 707 & $112412-05$ & Mudstone & Micrite & 21 \\
\hline 675 & LBG43B & Mudstone & Sandy micrite & 21 \\
\hline 673 & LBG41BA & -- & Quartzarenite & ss \\
\hline 670 & LBG42B & -- & Quartzarenite & ss \\
\hline 663 & LBG40BB & Grainstone & Intrasparite & 16 \\
\hline 608 & LBG39B & Grainstone & Intrasparite & 16 \\
\hline 530 & LBG36B & Mudstone & Micrite & 19 \\
\hline 520 & LBG29BB & Mudstone & Fossiliferous micrite & 9 \\
\hline 515 & LBG28B & Mudstone & Fossiliferous micrite & 9 \\
\hline 512 & $112412-07$ & Mudstone & Fossiliferous micrite & 9 \\
\hline 506 & LBG30B & -- & Quartzarenite & ss \\
\hline 493 & LBG31B & -- & Quartzarenite & ss \\
\hline 490 & LBG34BA1 & -- & Quartzarenite & ss \\
\hline 485 & LBG25B & Grainstone & Intrasparite & 16 \\
\hline 462 & LBG22B & Grainstone & Intrasparite & 16 \\
\hline 440 & LBG23B & Grainstone & Intrasparite & 16 \\
\hline 401 & $112412-04$ & Packstone & Intramicrite & 16 \\
\hline 398 & $112412-08$ & Wackestone & Intramicrite & 16 \\
\hline 350 & LBG15BA & Mudstone and wackestone & Micrite, intramicrite & 16 \\
\hline 348 & LBG14BB & Packstone & Intramicrite & 16 \\
\hline 345 & LBG20B & Wackestone & Intramicrite & 16 \\
\hline 338 & LBG16B & Grainstone & Intrasparite & 16 \\
\hline 305 & LBG13B & Wackestone & Biomicrite & 9 \\
\hline 267 & LBG18B & Grainstone & Intrasparite & 16 \\
\hline 263 & LBG4B & -- & Quartzarenite & ss \\
\hline 262 & LBG2B & -- & Quartzarenite & ss \\
\hline 255 & LBG8B & Wackestone & Intramicrite & 21 \\
\hline 252 & LBG10B & Mudstone & Micrite & 23 \\
\hline 250 & LBG9B & Mudstone & Micrite & 23 \\
\hline 227 & LBG3B & Mudstone & Micrite & 19 \\
\hline 223 & LBG1B & Mudstone & Micrite & 19 \\
\hline 200 & LBG5B & Mudstone & Micrite & 19 \\
\hline 185 & $112412-09$ & Packstone and wackestone & Biopelmicrudite & 8 \\
\hline 180 & $112412-03$ & Packstone & Biopelmicrudite & 8 \\
\hline 105 & $112412-02$ & Grainstone & Intrasparite & 16 \\
\hline 5 & $112412-01 \mathrm{~A}$ & Wackestone & Intramicrite & 23 \\
\hline
\end{tabular}

\footnotetext{
${ }^{1}$ The classification systems of Dunham (1962), Folk (1980), and Wilson (1975) were used to categorize the samples listed.

2 ' $\mathrm{ss}$ ' is used to indicate a thin section made from a sandstone sample.
} 


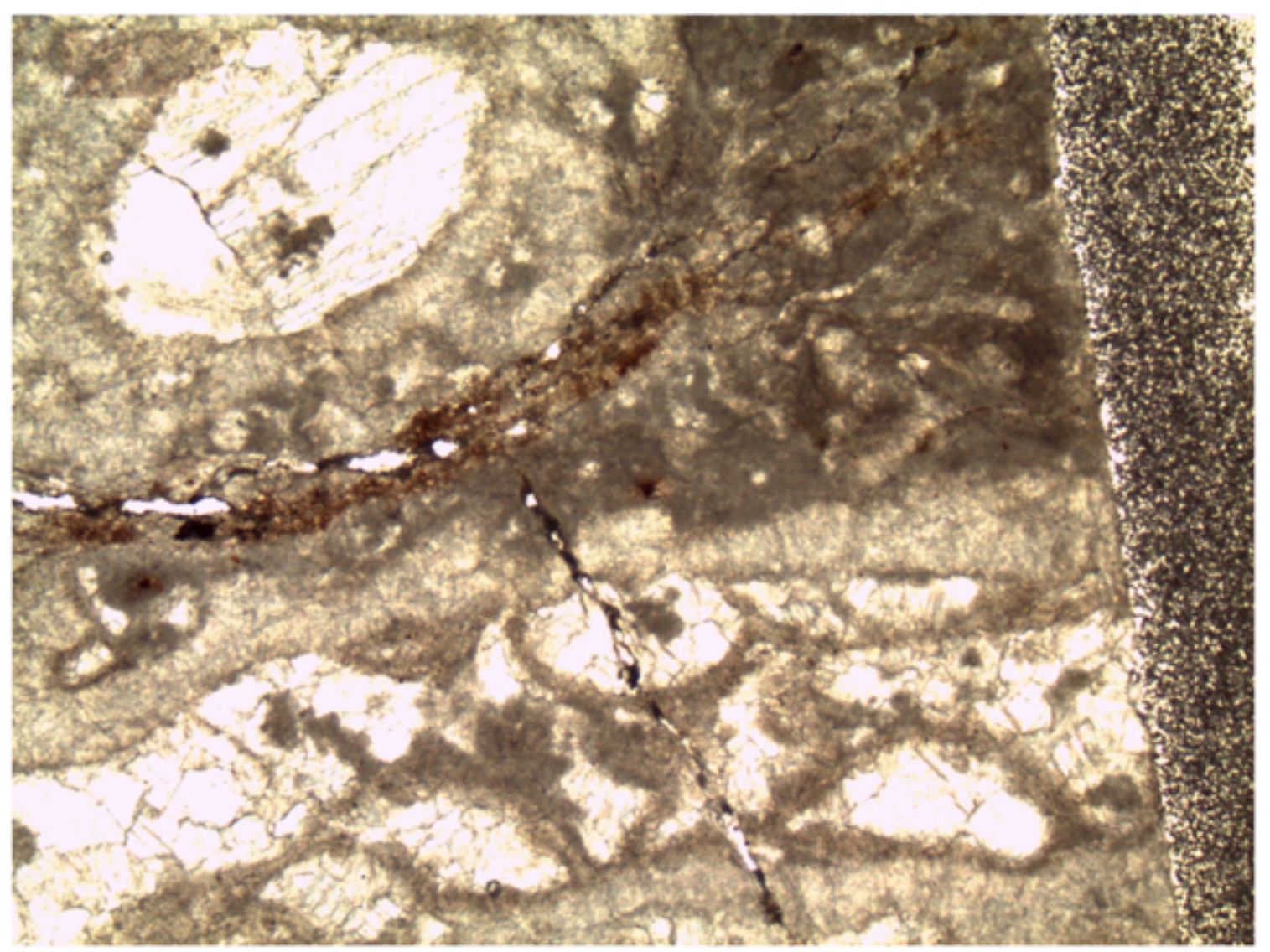

Figure 16. SMF 8, from thin section 112412-03, containing transverse (above) and longitudinal (below) section of Amphipora. Field of view is $1.16 \mathrm{~mm}$ wide.

Standard Microfacies 9. This microfacies (as shown in Fig. 17) is characterized by approximately $90 \%$ micrite with small allochems. In the Lost Burro Formation, these microfossils were (?) Tentaculites, ostracods, brachiopods and crinoid stem fragments. In addition to the microfossils, the thin sections contained small amounts of quartz silt or fine sand. Although there was greater allochem diversity, these thin sections had significantly lower allochem densities than the thin sections assigned to SMF 8. 


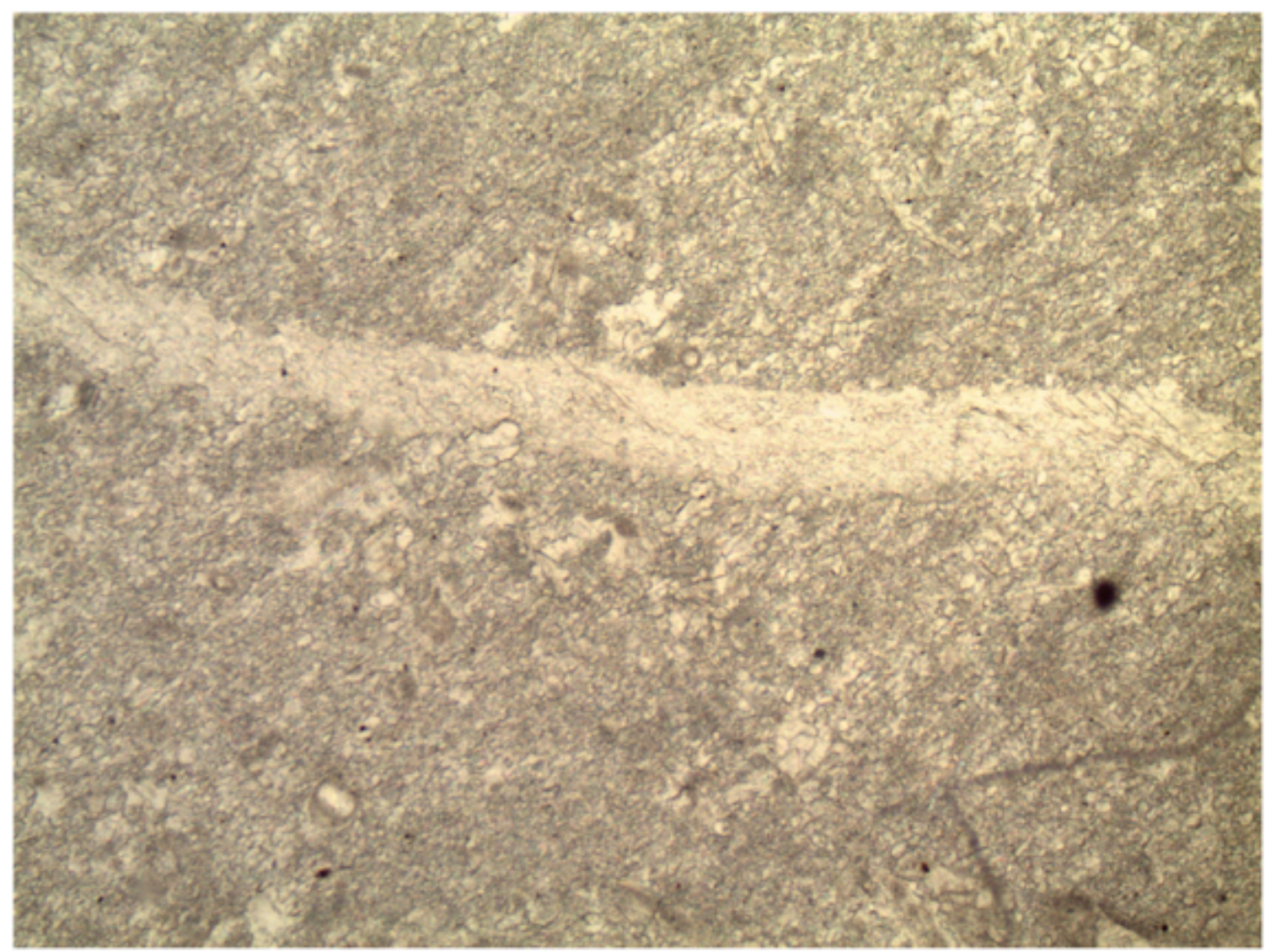

Figure 17. SMF 9, from thin section LBG13B, showing a brachiopod in micrite (field of view is $1.16 \mathrm{~mm}$ wide).

The four thin sections assigned to this SMF were fossiliferous micrites (three) and one biomicrite, using Folk's (1980) criteria. Considering Dunham's (1962) criteria, the Lost Burro SMF 9 samples were mudstones (three) or wackestone (one).

This microfacies differs from Wilson's definition in that three of the four samples were laminated instead of burrowed. They also contained far fewer fossils than are suggested in Wilson's definition, as he refers to SMF 9 as a 'bioclastic wackestone or bioclastic micrite' (Wilson, 1975) and only one of the Lost Burro samples was a 
wackestone. The fossil assemblage (dominated by open marine-favoring organisms) and the diversity of that assemblage were the criteria used to select this SMF.

Standard Microfacies 16. This microfacies (shown in Fig. 18) is the most immediately recognizable of the six standard microfacies identified, because the samples were predominantly composed of micritic intraclasts in spar or pseudospar. The distribution of the intraclasts was relatively even within each thin section and they ranged from angular to well rounded.

There were two distinct types of SMF 16 samples: SMF 16-non-laminated and SMF16-laminated. The former contained well rounded intraclasts with a high degree of sorting. The SMF 16-laminated samples were composed of unsorted, angular to subangular intraclasts that were interstratified with wavy micritic laminae.

The fossils present in thin sections assigned to SMF 16 ranged from $\sim 1 \%$ to $15 \%$ of the rock volume. Amphipora was the most typical fossil found in this SMF, but (?) Tentaculites and ostracods were found locally in beds assigned to this standard microfacies. Pellets and quartz silt were also found locally. However, allochem distribution depended on sub-type. The SMF 16-laminated samples contained very few fossils ( $\sim 1 \%)$ and these were mostly Amphipora with local ostracods or (?) Tentaculites. Only the laminated samples contained quartz silt. The SMF 16-non-laminated samples had higher percentages of allochems (up to $15 \%$ ). 


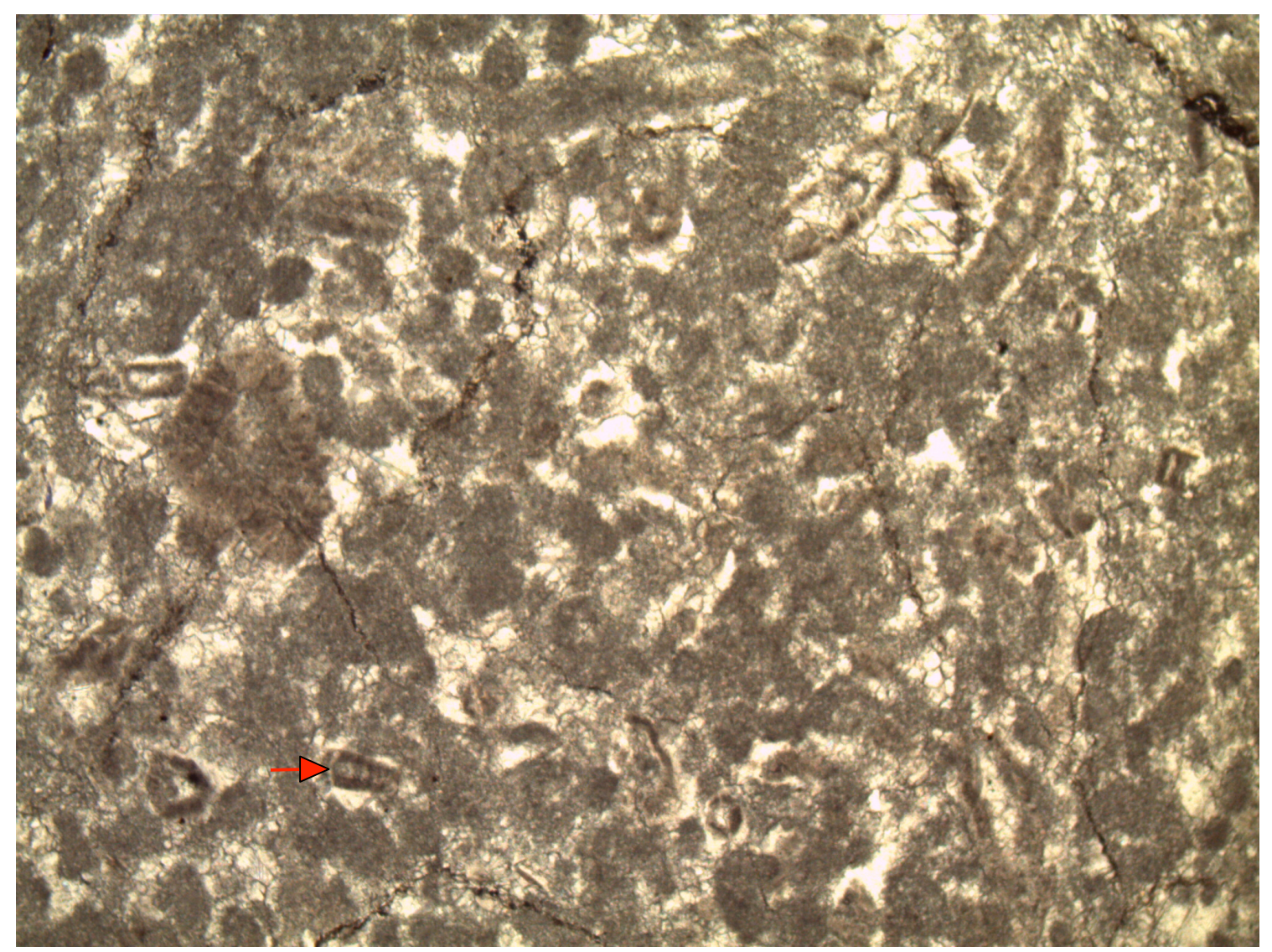

Figure 18. SMF 16, from thin section LBG40BB, showing micritic intraclasts and Tentaculites (red arrow). Field of view is $1.16 \mathrm{~mm}$ wide.

The interstitial material tended to be spar or pseudospar rather than micrite. The interstitial material in half of the thin sections assigned this SMF was thought to be recrystallized micrite based upon the presence of pseudospar patches that were larger than nearby intraclast grains. Recrystallization does make it difficult to be certain, but these thin sections were interpreted to contain pseudospar rather than authigenic spar. Most of these were SMF 16-laminated (with laminae of micrite).

Half of the thin sections assigned to this SMF show sparry characteristics, containing intraclasts that show no recrystallization, for example, or lacking the features 
previously mentioned as pseudospar indicators. The spar was found in the gaps between the $100-\mu \mathrm{m}$ intraclasts that formed the grain support for the thin sections. These thin sections were all classified as SMF 16-non-laminated.

The fifteen thin sections identified as SMF 16 ranged from intrasparite (ten) to intramicrite (four) to micrite interlaminated with intramicrite (one). Under Dunham's (1962) classifications the thin sections were grainstones (ten), packstone (two), wackestone (two) or mudstone interlaminated with wackestone (one).

This microfacies differs from Wilson's definition of SMF 16 in several respects. First, the spar can be pseudospar rather than authigenic cement. Wilson's grainstones are thus sometimes packstones or wackestones in this sample set. However, Flügel's interpretations (2004) of SMF 16 allow for packstones, so this interpretation falls within the more recent set of descriptions.

A second contrast to Wilson's SMF 16 is that the dominant components in the thin sections were sand-sized micritic intraclasts rather than pellets. There was one thin section (112412-02) that contained pellets, but it is not representative of the Lost Burro Gap SMF 16 samples in this regard. Flügel's (2004) interpretations of SMF 16 refer to this microfacies as containing peloids. Flügel's (2004) description of SMF 16-laminated includes the intraclasts being bound together by microbial laminations, making them bindstones. The Lost Burro samples were not bindstones, and lacked microbial laminations. The wavy laminations present were micritic in composition.

Finally, the samples recognized as SMF 16 in Lost Burro Gap lacked any foraminifera. Instead, Amphipora was the dominant fossil. Flügel includes an 
assortment of allowable fossils in his SMF 16-nonlaminated, including foraminifera, ostracods or calcispheres (Flügel, 2004). Ostracods were present in two of the Lost Burro Gap samples.

Standard Microfacies 19. This microfacies is characterized by fine-grained, laminated micrite, as shown in Figure 19. This microfacies locally contained small amounts of quartz silt. The four Lost Burro Gap samples were micrites under Folk's (1980) classification, and were mudstones under Dunham's (1962) classification.

Samples were assigned to this microfacies based upon Wilson's description ("laminated to bioturbated pelleted lime mudstones") and his note that mudstones with only scattered allochems could occur (Wilson, 1975). Whereas none of the thin sections from the Lost Burro Gap contained pellets, they were composed of laminated micrite with few fossils. Flügel (2004) also describes SMF 19 as having rare fossils and microbial laminae. While the samples did not contain microbial laminations, they otherwise fit the definition for this SMF.

Standard Microfacies 21. The majority of samples assigned to this microfacies were also laminated micrite with very few allochems, but they were distinct from those of SMF 19 in that four of the five SMF 21 samples contained fenestral features. This microfacies is also different in that all the samples contain laminae of micritic intraclasts in pseudospar, which is not true of the SMF 19 samples. Figure 20 shows the fabric typical of this standard microfacies. Silt- and fine sand-sized quartz grains were present in four of the five samples. 


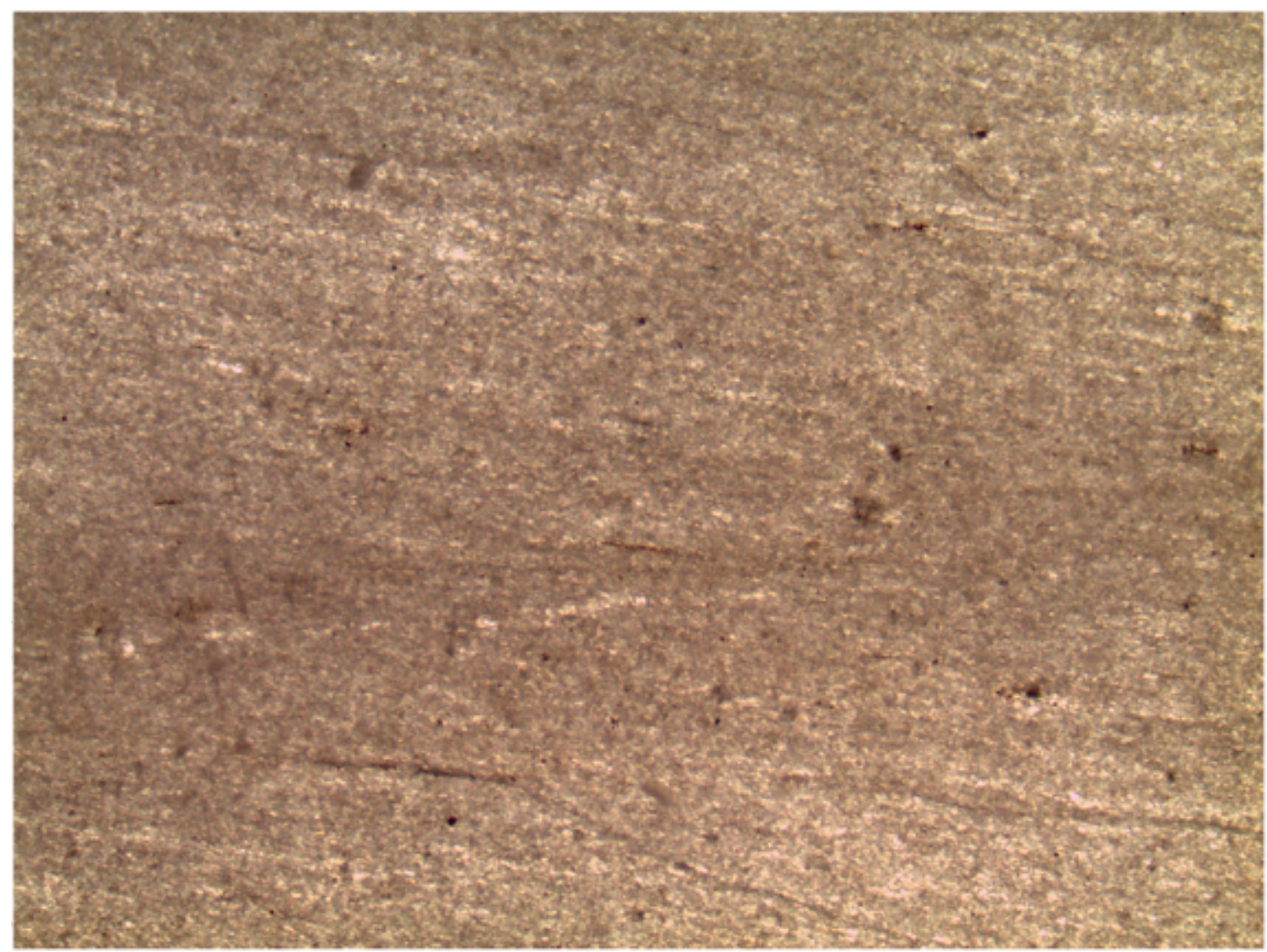

Figure 19. SMF 19, from thin section LBG3B, showing laminated micrite (field of view is $2.96 \mathrm{~mm}$ wide).

The texture observed in the Lost Burro Gap samples was that of alternating laminations of micrite and intramicrite (three samples) or micrite and sandy layers (two samples). The intramicrite laminations were composed of irregular micritic intraclasts with interstitial pseudospar and fenestrae. These fenestrae could be larger in size than nearby intraclasts. The five samples ranged from mudstone (three) to wackestone (one) to packstone (one). Under Folk's classification scheme, the samples ranged from micrite (two) or sandy micrite (one) to intramicrite (two). 


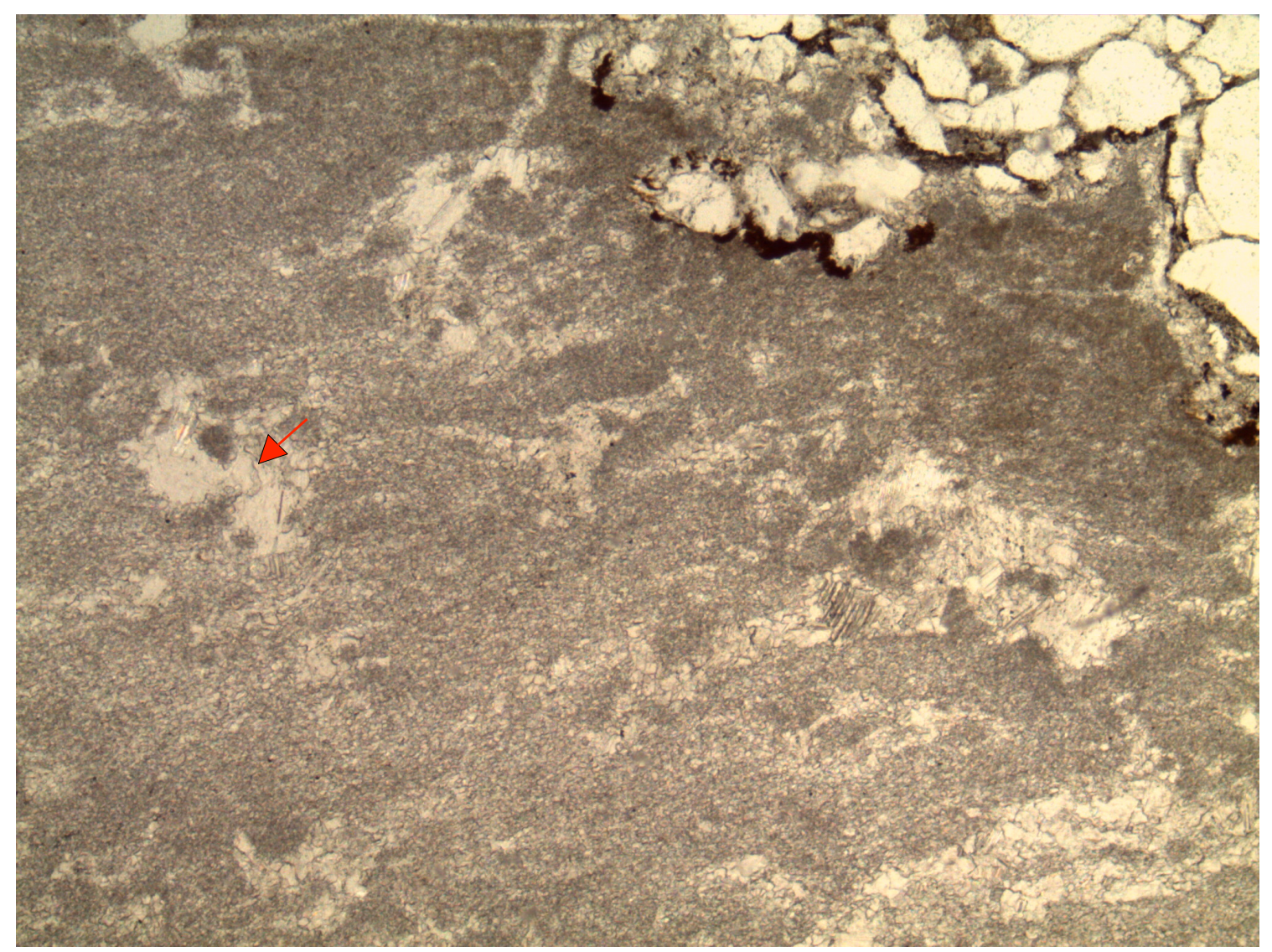

Figure 20. SMF 21, from thin section LBG43B, showing a fenestral opening (red arrow) and sandstone layer in micrite (field of view is $2.96 \mathrm{~mm}$ wide).

These samples differ from Wilson's definition of SMF 21 in that they were not bound together by algae. However, they shared a similar fabric and four of the samples also contained fenestral features, and the environment these samples preserve was thought to be equivalent to Wilson's interpretation. Using Flügel's (2004) modifications of Wilson's SMF definitions, these samples fit into the description for SMF 21 based solely on fabric.

Standard Microfacies 23. This microfacies is the simplest of the six recognized in thin sections from the Lost Burro Formation. It is composed primarily of 
homogeneous, unlaminated micrite with very few fossils $(<1 \%)$. Figure 21 shows the features typical of this SMF. This microfacies locally contained stringers of quartz silt and sand, peloids, and micritic intraclasts, and one thin section (LBG9B) contained replacement chert. The chert nodules in this sample contained crystals radiating from the central grain boundary. These radiating chert fibers were length slow. Minerals display length slow properties when the slow optical direction (the direction of maximum refractive index) is parallel to the long axis of the mineral's crystal structure. This is visible as a decrease in interference color when a quartz wedge is introduced.

The five thin sections assigned to this microfacies ranged from unlaminated, homogeneous, unfossiliferous micrite (four) to intramicrite (one). The Lost Burro Formation SMF 23 samples ranged from mudstone (four) to wackestone (one) under Dunham's (1962) classification.

This microfacies differs from Wilson's definition in that one of the thin sections contained micritic intraclasts in significant quantity $(25 \%)$ and many of the thin sections contained quartz silt. This does not match Wilson's specification of "homogeneous... pure micrite" (Wilson, 1975) for SMF 23. The intraclast-rich thin section was otherwise unlaminated micrite, and the intraclasts lacked the degree of rounding used to recognize samples as SMF 16-laminated. It was classified as SMF 23 due to the character of the supporting material.

\section{Standard Microfacies and Color}

The field observations of color were not useful in predicting the eventual assignment of standard microfacies (SMF). 


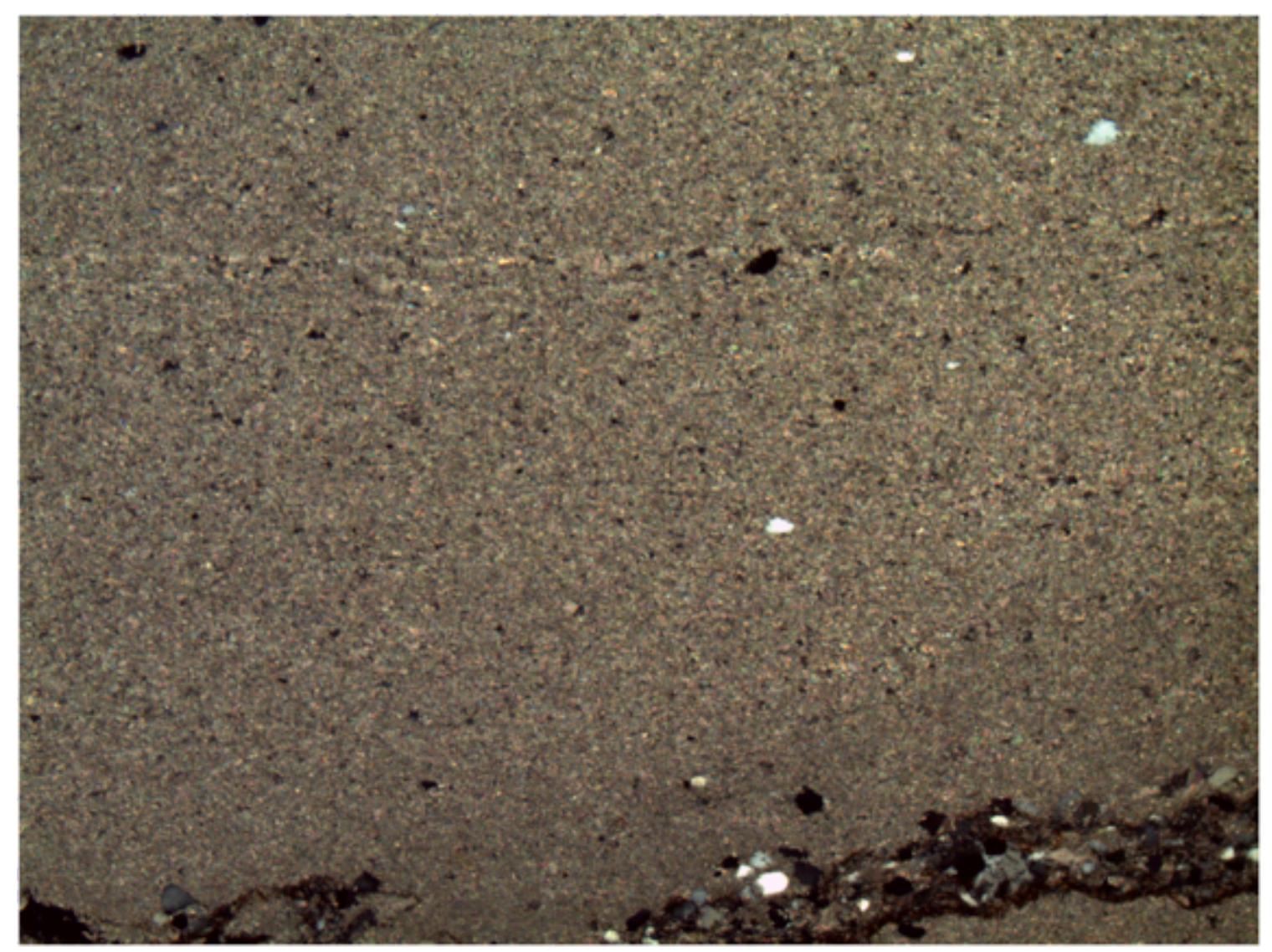

Figure 21. SMF 23, from thin section LBG9B, showing unlaminated micrite (field of view is $1.16 \mathrm{~mm}$ wide).

Table 3 shows the variations in color and weathered color associated with each of the standard microfacies recognized in this study.

The Munsell designations were determined using fresh and weathered surfaces of hand samples from which thin sections were made. The values shown in bold are the most commonly occurring within each sample set.

The darker carbonate rocks are primarily dark gray (N3) to medium dark gray (N4), though they can weather significantly lighter, ranging from medium dark gray (N4) to medium gray (N5) to light olive gray (5Y6/1) and pale yellowish brown (10YR6/2). 
TABLE 3. MUNSELL COLORS ASSOCIATED WITH LOST BURRO FORMATION STANDARD MICROFACIES (SMFS)

\begin{tabular}{|c|c|c|}
\hline SMF & Colors & Weathered Colors \\
\hline 8 & $\mathrm{~N} 3, \mathrm{~N} 4, \mathrm{~N} 5$ & $5 \mathrm{Y} 6 / 1, \mathrm{~N} 4$ \\
\hline 9 & $\mathbf{N 3}, \mathrm{N} 4$ & 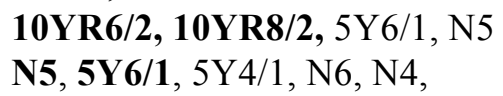 \\
\hline 16 & $\mathrm{~N} 4, \mathrm{~N} 5, \mathrm{~N} 3$ & $10 \mathrm{YR} 6 / 2$ \\
\hline 19 & $\mathrm{~N} 4, \mathrm{~N} 5$ & N6, 5Y4/1 \\
\hline 21 & N4, N6-N7, N3 & $5 \mathrm{Y} 4 / 1, \mathrm{~N} 7$ \\
\hline 23 & $\mathbf{5 Y 6 / 1}, 5 \mathrm{Y} 4 / 1, \mathrm{~N} 5, \mathrm{~N} 3$ & $10 \mathrm{YR} 6 / 2, \mathrm{~N} 4$ \\
\hline
\end{tabular}

The lighter samples are commonly medium dark gray (N4) to medium gray (N5) and weather lighter still (light olive gray [5Y6/1] to pale yellowish brown [10YR6/2] to medium light gray [N6]). However, for no single SMF was there a single consistent color. Table 4 shows the variations observed across all SMF 16 samples. For this table, darker colors such as dark gray (N3) are left justified, with colors in the medium to medium light range justified to the right (N5 and lighter, which includes light olive gray, medium light gray, and light gray). Note that in three samples, the weathered color is the same as the fresh color.

Whereas both dark-gray and medium-gray samples exist, the most common color found in samples classified as SMF 16 is medium dark gray. Again, though weathered colors in this sample set include samples that are medium dark gray, it is more common to find that these samples occur in beds that have weathered to lighter colors. This trend is also true of samples with other SMF values, particularly for SMF 19 and SMF 21.

When examining the measured section as a whole, the variation in colors is subtle (ranging from $\mathrm{N} 3$ to N5) until the weathered colors are taken into account. 
TABLE 4. MUNSELL COLORS ASSOCIATED WITH STANDARD MICROFACIES (SMF) 16

\begin{tabular}{|c|c|c|c|c|c|c|c|}
\hline Thin Section & SMF & & Color & & \multicolumn{3}{|c|}{ Weathered Color } \\
\hline LBG57B & 16 & N3 & & & & N4 & \\
\hline LBG44BB & 16 & & & N5 & & & $5 Y 6 / 1$ \\
\hline LBG40BB & 16 & & & N5 & & & $5 Y 6 / 1$ \\
\hline LBG39B & 16 & & N4 & & & N4 & \\
\hline LBG25B & 16 & & N4 & & & & N6 \\
\hline LBG22B & 16 & & N4 & & & & N5 \\
\hline LBG23B & 16 & & & N5 & & & N5 \\
\hline $112412-04$ & 16 & & N4 & & & & N5 \\
\hline $112412-08$ & 16 & & N4 & & & & N5 \\
\hline $15 \mathrm{BA}$ & 16 & & N4 & & $5 \mathrm{Y} 4 / 1$ & & \\
\hline 14BB & 16 & & & N5 & & & N6, 5Y6/1 \\
\hline $20 \mathrm{~B}$ & 16 & & N4 & & & & N6 \\
\hline LBG16B & 16 & & & N5 & & & $5 Y 6 / 1$ \\
\hline 18B & 16 & & N4 & & & $10 \mathrm{YR} 6 / 2$ & \\
\hline $112412-02$ & 16 & $\mathrm{~N} 3$ & & & $\mathrm{~N} 3$ & & \\
\hline
\end{tabular}

At the outcrop, it is the weathered colors that are apparent and that produce the striped appearance of the Lost Burro Formation.

The sandstones also contribute to the banded appearance of the Lost Burro Formation. The fresh surfaces of the sandstone beds range from medium dark gray (N4) to light olive gray (5Y6/1), though the weathered surfaces are significantly different. The weathered colors range from grayish brown (5YR3/2), dark yellowish orange (10YR6/6), moderate brown (5YR4/4), and moderate yellowish brown (10YR5/4) on the dark end, to very pale orange (10YR8/2) and light olive gray (5Y6/1) on the lighter end. This yellowand brown-toned weathering is restricted to the sandy layers within carbonate beds or sandstone beds, and is distinct from carbonates without sand content. 


\section{Sandstone}

Thin sections were made of sandstone samples from the measured section, but they lacked the diversity of characteristics shown in the carbonate thin sections. In general, the sandstones were poorly sorted and grain supported, with interstitial lime mud and/or carbonate cement. The fine to coarse sand-sized quartz grains $(0.2-0.7 \mathrm{~mm})$ ranged from well rounded to sub-angular. These grains had shapes ranging from elongate to round with equal axes. The silt-sized quartz grains $(0.02-0.04 \mathrm{~mm})$ ranged from well rounded to sub-rounded with rare sub-angular grains and were mostly round with equal axes. Regardless of size, many quartz particles showed calcite replacement on their edges. The grains had mostly straight extinction, although some of the larger grains showed undulatory extinction.

Other minerals found in the sandstone thin sections included microcline (LBG2B, LBG4B, LBG34BA1\&2, LBG42B, LBG47B), tourmaline inclusions in quartz (LBG30B, LBG50B) and tourmaline as separate grains (LBG4B, LBG8B, LBG31B, LBG34BA2, LBG41BA, LBG42B, LBG43B, LBG47B). Some thin sections (LBG30B, LBG31B, LBG34BA1\&2, LBG41BA, LBG47B, LBG50B) had micritic intraclasts between quartz grains. Some of the thin sections had intraclasts that contained (?) Tentaculites (LBG30B, LBG31B, LBG34BA1\&2, LBG41BA, LBG47B).

Some thin sections showed layering within the sandstone. LBG2B and LBG34BA1 had distinct layers of coarse, poorly sorted sand that were overlain by finer, moderately sorted sand. 


\section{INTERPRETATIONS}

\section{Inferred Depositional Environments}

Interpretations of the depositional environment of the carbonate rocks were aided by the Standard Microfacies of Wilson (1975), which are structured into facies belts of commonly associated environments.

\section{SMF 8}

SMF 8 was characterized by the presence of Amphipora in high density (30-60\%) with interstitial micrite. At the denser end of that range, the Amphipora locally larger than $2 \mathrm{~mm}$ in size provided grain support for the carbonate. Peloids were only found in significant amounts $(10 \%)$ in one thin section. Amphipora was the dominant organism recognized within these samples, though ostracods were also present.

Using the classification of Folk (1980), the six Lost Burro samples in this microfacies ranged from biomicrites to biopelmicrudites and one biomicrudite. Using the classification of Dunham (1962), the samples were packstones or wackestones.

This standard microfacies was inferred to be one of the two subtidal microfacies recognized in the Lost Burro samples. Based on the fossil assemblage, both in thin section and in field observations, it was interpreted as an open lagoon or otherwise subtidal facies below wave base. This interpretation is one of the possibilities under Wilson's specifications. His Facies Belt 7 (shelf lagoons) can include SMF 8 (Wilson, 1975). Flügel (2004) interpreted this SMF to represent a shelf lagoon. One of Flügel's interpretations of SMF 8 is of a "nearly monospecific biota" (in this case, Amphipora) with fine-grained bioclasts and a micritc matrix (Flügel, 2004). This subtidal 
interpretation would fit with the observations of abundant Amphipora and isolated corals in the field at Lost Burro Gap, as shown in the measured section (Appendix 1). Many previous workers on Devonian carbonate systems containing Amphipora have inferred that the organism lived in a restricted lagoonal environment (Kyle, 1981; Galli, 1985; Witzke and Bunker, 1997; Hladil, 2007; Jannusch, 2008; Schneider et al., 2013). Other workers concluded that Amphipora lived in an open marine environment. However, in a previous study conducted on coeval deposits in eastern Nevada, Elrick (1995) also interpreted monospecific Amphipora beds to represent restricted marine environments. The corals, however, were stenohaline.

Field observations of this standard microfacies included dense concentrations of Amphipora. Petrographic work supports these observations. The high density of the allochems in the Lost Burro samples indicates an environment in which these organisms were concentrated.

\section{SMF 9}

SMF 9 was characterized by $1-11 \%$ small allochems in micrite, with local quartz silt or fine sand. Under Dunham's (1962) classification, the samples were mudstones (three) or wackestone (one). Under Folk's (1980) classification, the samples ranged from fossiliferous micrites (three) to biomicrite (one).

The abundance of micrite, the nature of the fossils identified in the thin sections ((?) Tentaculites, ostracods, crinoid stem fragments, and brachiopods), and the variety of those fossils were interpreted to reflect a shallow, euphotic, subtidal environment with open marine circulation. These samples are included under the interpretation as a 
shallow lagoon with open circulation that Flügel described (Flügel, 2004) because Flügel's (2004) expansion on Wilson's (1975) standard microfacies allows for two types of preserved environments.

Field observations of beds associated with this standard microfacies included the presence of solitary rugose corals in Layers 7 and 13 and massive stromatoporoids in Layer 7, both of which would suggest open marine subtidal environments.

\section{SMF 16-non-laminated}

SMF 16-non-laminated was predominantly characterized by grain-supported, sand-sized micritic intraclasts, with interstitial authigenic spar. Fossils were typically (?) Tentaculites, Amphipora, and ostracods. Local pellets were also found. Using Dunham's (1962) classification, the eight Lost Burro samples were grainstones. Using Folk's (1980) classification, the samples were intrasparites.

This microfacies was interpreted as part of a tidal flat complex, with the SMF 16non-laminated samples representing a tidal channel in which the rounded and well sorted intraclasts were repeatedly washed and rolled during tidal action. This environment would be intertidal and below the normal high tide line, with frequent submersion. Almost all of the intraclasts were sand-sized, with very few pebble-sized intraclasts, and from this high degree of sorting a high-energy depositional environment was inferred. The high energy of this environment was inferred not only from the sorting and the rounding of the intraclasts, but also the lack of a micritic matrix. The fossils were washed in from deeper environments. 


\section{SMF 16-laminated}

The SMF 16-laminated samples were predominantly characterized by grainsupported, sand-sized micritic intraclasts, most with interstitial pseudospar (recrystallized micrite). Fossils were typically Amphipora, though local (?) Tentaculites and ostracods were present. These fossils accounted for very little sample volume $(\sim 1 \%)$. Quartz silt was also present in the SMF 16-laminated samples. Using Dunham's (1962) classification, the seven Lost Burro samples were mudstone interlaminated with wackestone (one), or either wackestone (two), packstone (two), or grainstone (two), all of which were interlaminated with mudstone. Using Folk's (1980) classification, the samples were mostly intramicrites with two intrasparites, all interlaminated with micrite.

These samples could represent the tidal flat through which the SMF 16-nonlaminated tidal channels cut, with much less washing and sorting than in the deeper channel. This environment would also be intertidal and occur below the normal high tide line. The lesser amount of transport was interpreted from the much poorer degree of sorting and rounding in the Lost Burro samples assigned to SMF 16-laminated. The quartz silt present in these samples was inferred to have come from a terrestrial source.

There are changes to Wilson's (1975) definition of SMF 16 in this interpretation. Some samples were packstones rather than grainstones, and there was interstitial recrystallized micrite rather than interstitial cement in five samples. However, Flügel's (2004) definition allows for these changes, and thus the general environment was inferred to be the same as in Wilson's SMF 16. This SMF (both laminated and non-laminated 
sub-categories) was interpreted to be shallower than SMF 8 or SMF 9, but deeper than the remaining SMFs recognized in the measured section.

\section{SMF 19}

SMF 19 was characterized by fine-grained, laminated micrite. It also locally contained quartz silt. The laminations were visible in the field as well as in thin section. Under Folk's (1980) classification scheme, the four Lost Burro samples were micrites. Using Dunham's (1962) classification scheme, they were mudstones.

This standard microfacies was interpreted as a very restricted marine setting such as an upper intertidal pond just below the high tide line, or a lagoon within a protected environment that underwent frequent episodes of exposure. The laminations are a sign of little water movement and the lack of bioturbation. The lack of burrowing organisms suggests an upper intertidal environment or an area where the salinity of the environment was too extreme for burrowing organisms. Flügel (2004) interpreted SMF 19 as

preservation of a tidal flat. This SMF was interpreted to be shallower than SMF 8, 9, and 16, but deeper than SMF 21 and SMF 23.

\section{SMF 21}

This microfacies also was characterized by laminated micrite with quartz sand and silt and few allochems. It was distinguishable from SMF 19 by the presence of laminae consisting of irregularly sized intraclasts surrounded by irregularly sized patches of pseudospar in all samples, some of which were birdseye fenestrae in four of the samples. The micrite around the intraclasts had been recrystallized to pseudospar. The size of some of the pseudospar was larger than nearby micrite intraclasts, so these patches 
cannot be pore-filling cement. It is unlikely that the allochems were also recrystallized. Some of the pseudospar patches, though irregular, were equant in dimensions and were thought to be birdseye fenestrae. The color of the beds containing the samples classified as SMF 21 ranged from dark gray to light gray. All of the samples were taken from beds with laminations visible in the field.

Under the classification scheme of Folk (1980), the Lost Burro samples were intramicrites, sandy micrite, or micrite. Using the classification scheme of Dunham (1962), the five samples were predominantly mudstones, with one wackestone and one packstone.

This environment was interpreted as a very shallow upper intertidal environment; it could be an intertidal pond or the landward edge of an intertidal flat. It would occur at or just above the normal high tide line. The fenestral openings signify significant exposure, though the presence of the intraclasts indicates that some sand-sized allochems may have been torn up and transported during submersion. It was interpreted to be deeper than SMF 23, but shallower than SMF 19.

\section{SMF 23}

This microfacies was characterized by unlaminated, homogenous micrite with $<1 \%$ fossils. In some cases, the thin sections contained stringers of quartz silt and sand, peloids, or micritic intraclasts. These intraclasts accounted for $25 \%$ of the thin sections in which they were present. One thin section contained replacement chert. These samples were grouped together because they were predominantly composed of unlaminated micrite and contained almost no fossils. 
This SMF was interpreted to represent upper intertidal conditions. Under Dunham's (1962) classification system, these five Lost Burro samples were wackestones or mudstones. Using Folk's (1980) classifications, the samples were micrites or intramicrite. Samples came from beds that did not show a consistent color from bed bottom to bed top. One of the beds showed another transitional characteristic (a gradational boundary with the underlying carbonate layer), though this characteristic was not diagnostic of this standard microfacies.

This microfacies was interpreted as the shallowest of the intertidal facies. It was interpreted as a tidal pond or supratidal flat based on the replacement chert with lengthslow crystals (LBG9B) and the exceedingly small percentage of biogenic allochems in the host micrite. Length slow chalcedony is a common replacement of evaporites in carbonate rocks (Folk and Pittman, 1971), and evaporites are typical as precipitates from seawater in very shallow intertidal or supratidal environments (Lucia, 1972). This environment would occur above normal high tide line but within the range of stormdriven water. Flügel (2004) interprets this SMF as preservation of a tidal flat or evaporative tidal pond. The intraclasts could thus occur at the edge of a tidal flat, or represent a depression that collected reworked micritic intraclasts.

\section{Sandstone}

The nine sandstone thin sections were interpreted to represent supratidal environments. These environments would occur near to and shallower than the high tide line, though the lime mud and carbonate cement indicates there was episodic washing with sea water. These samples are indicative of an interval of time when terrestrial 
sediment flooded the area. The sedimentary structures referenced by Yang et al. (1995) such as planar and trough cross-laminations, planar to wavy laminations, and climbing ripple laminations, were not observed in the measured section for this study.

\section{Parasequences}

The standard microfacies designation for each thin section described here was combined with field observations in order to outline parasequence boundaries and determine if any periodic repetition of environments existed. Table 5 repeats the summary of thin section classifications and shows the parasequence boundaries and layer assignments. A parasequence is defined here as a conformable set of beds with more than two interpreted sub-environments, showing changes in inferred depth within the set and bounded at the base and top by flooding surfaces. The changes within the parasequence could represent either shallowing-upward or deepening-upward. All changes within the parasequence were used to determine the overall trend in depth change. The definition of a marine flooding surface is "a surface that separates younger from older strata, across which there is evidence of an abrupt increase in depth" (Van Wagoner et al., 1988). For instance, these surfaces are recognized where a layer with subtidal or intertidal characteristics overlies a supratidal layer. The base of that overlying layer is inferred to represent a marine flooding surface.

Within the measured section, seven complete parasequences and one incomplete parasequence were recognized. Figure 22 displays the full stratigraphic section showing sample locations, the inferred depth, and the parasequence boundaries. 
TABLE 5. SAMPLE CLASSIFICATIONS SHOWING PARASEQUENCE ASSIGNMENTS

\begin{tabular}{|c|c|c|c|c|c|}
\hline Layer & Parasequence & $\overline{T \text { TS \# }}$ & Dunham & Folk & Wilson \\
\hline 21 & 8 & LBG60B & Packstone & Biomicrite & 8 \\
\hline 21 & 8 & LBG58B & Wackestone & Biomicrite & 8 \\
\hline 20 & 8 & LBG56B & Wackestone & Biomicrudite & 8 \\
\hline 20 & 8 & $112412-06$ & Wackestone & Biomicrite & 8 \\
\hline 20 & 8 & LBG57B & Grainstone & Intrasparite & 16 \\
\hline 19 & 8 & LBG53B & Mudstone & Micrite & 21 \\
\hline 19 & 8 & LBG52B & Mudstone & Micrite & 23 \\
\hline 19 & 8 & LBG51B & Mudstone & Micrite & 23 \\
\hline 18 & 7 & LBG50B & -- & Quartzarenite & ss \\
\hline 18 & 7 & LBG47B & -- & Quartzarenite & ss \\
\hline 17 & 7 & LBG44BB & Grainstone & Intrasparite & 16 \\
\hline 17 & 7 & LBG45B & Packstone & Intramicrite & 21 \\
\hline 17 & 7 & $112412-05$ & Mudstone & Micrite & 21 \\
\hline 17 & 7 & LBG43B & Mudstone & Sandy micrite & 21 \\
\hline 16 & 6 & LBG41BA & -- & Quartzarenite & ss \\
\hline 16 & 6 & LBG42B & -- & Quartzarenite & ss \\
\hline 15 & 6 & LBG40BB & Grainstone & Intrasparite & 16 \\
\hline 14 & 5 & LBG39B & Grainstone & Intrasparite & 16 \\
\hline 14 & 5 & LBG36B & Mudstone & Micrite & 19 \\
\hline 13 & 5 & LBG29BB & Mudstone & Fossiliferous micrite & 9 \\
\hline 13 & 5 & LBG28B & Mudstone & Fossiliferous micrite & 9 \\
\hline 13 & 5 & $112412-07$ & Mudstone & Fossiliferous micrite & 9 \\
\hline 12 & 4 & LBG30B & -- & Quartzarenite & ss \\
\hline 12 & 4 & LBG31B & -- & Quartzarenite & ss \\
\hline 12 & 4 & LBG34BA1 & -- & Quartzarenite & ss \\
\hline 10 & 4 & LBG25B & Grainstone & Intrasparite & 16 \\
\hline 10 & 4 & LBG22B & Grainstone & Intrasparite & 16 \\
\hline 10 & 4 & LBG23B & Grainstone & Intrasparite & 16 \\
\hline 10 & 4 & $112412-04$ & Packstone & Intramicrite & 16 \\
\hline 9 & 4 & $112412-08$ & Wackestone & Intramicrite & 16 \\
\hline 9 & 4 & LBG15BA & Mudstone and wackestone & Micrite, intramicrite & 16 \\
\hline 9 & 4 & LBG14BB & Packstone & Intramicrite & 16 \\
\hline 9 & 4 & LBG20B & Wackestone & Intramicrite & 16 \\
\hline 7 & 3 & LBG16B & Grainstone & Intrasparite & 16 \\
\hline 7 & 3 & LBG13B & Wackestone & Biomicrite & 9 \\
\hline 6 & 3 & LBG18B & Grainstone & Intrasparite & 16 \\
\hline 5 & 2 & LBG4B & -- & Quartzarenite & ss \\
\hline 5 & 2 & LBG2B & -- & Quartzarenite & ss \\
\hline 4 & 2 & LBG8B & Wackestone & Intramicrite & 21 \\
\hline 4 & 2 & LBG10B & Mudstone & Micrite & 23 \\
\hline 4 & 2 & LBG9B & Mudstone & Micrite & 23 \\
\hline 4 & 2 & LBG3B & Mudstone & Micrite & 19 \\
\hline 4 & 2 & LBG1B & Mudstone & Micrite & 19 \\
\hline 4 & 2 & LBG5B & Mudstone & Micrite & 19 \\
\hline 3 & 2 & $112412-09$ & Packstone and wackestone & Biopelmicrudite & 8 \\
\hline 3 & 2 & $112412-03$ & Packstone & Biopelmicrudite & 8 \\
\hline 3 & 2 & $112412-02$ & Grainstone & Intrasparite & 16 \\
\hline 1 & 1 & 112412-01A & Wackestone & Intramicrite & 23 \\
\hline
\end{tabular}




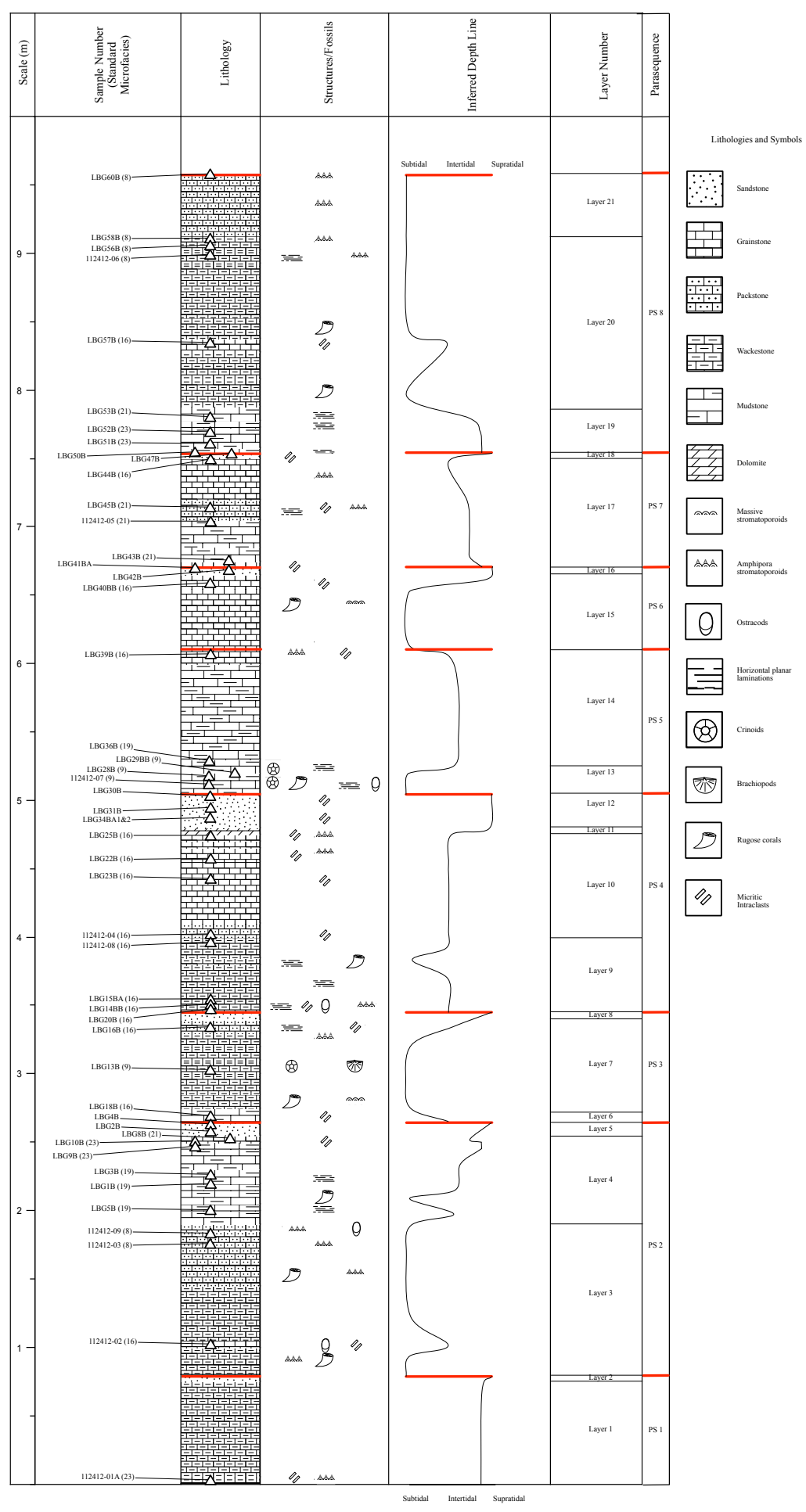

Figure 22. Measured section with sample locations and inferred depth line. Red lines mark parasequence boundaries, and triangles mark sample locations. 
Table 6 summarizes the respective thicknesses of each parasequence within the measured section.

\section{TABLE 6. THICKNESSES OF PARASEQUENCES}

\begin{tabular}{cccc}
\hline \hline Parasequence & Base (cm) & Top (cm) & $\begin{array}{c}\text { Thickness } \\
\text { (cm) }\end{array}$ \\
\hline 8 & 758 & 963 & 205 \\
7 & 675 & 758 & 83 \\
6 & 610 & 675 & 65 \\
5 & 510 & 610 & 100 \\
4 & 345 & 510 & 165 \\
3 & 265 & 345 & 80 \\
2 & 80 & 265 & 185 \\
1 & 0 & 80 & 80 \\
\hline
\end{tabular}

\section{Parasequence 1}

Starting at the base of the measured section, parasequence 1 extends from $0 \mathrm{~cm}$ (the bottom of the section) to $80 \mathrm{~cm}$ (Table 6). The bottom of this parasequence is marked by a sharp boundary with the underlying sandstone. The lower part of parasequence 1 (Layer 1) is fine-grained, dark-gray wackestone/intramicrite that contains a few small allochems identified as Amphipora (Fig. 22).

Thin section 112412-01A (Table 5) was taken from the base of this parasequence. It contained scattered quartz silt and sand grains, and approximately $25 \%$ micritic intraclasts. This thin section was classified as SMF 23 and interpreted to preserve an upper intertidal facies. The fragments of Amphipora present were inferred to have washed in. Most of the parasequence consists of dark-gray wackestone and was interpreted as an upper intertidal pond. 
The top of this parasequence is placed at the top of a lenticular sand bed that tapers to sandy stringers in the wackestone (Layer 2). The thickest part of this sand lens can be seen in Figure 14. Given the tapering of the sand lens, the sharp boundary between sand and underlying carbonate, and the discontinuous nature of the deposit, the sandstone was considered to represent supratidal conditions or terrestrial deposition upon an exposed carbonate platform.

This parasequence is mostly intertidal. It has a thin supratidal cap at the top, and it lacks a clear subtidal environment. Table 5 indicates the thin section from this parasequence and the layer from which it was taken.

\section{Parasequence 2}

The top of the second parasequence was placed at $265 \mathrm{~cm}$ above the base of the measured section, as shown in Table 6, giving the parasequence a thickness of $185 \mathrm{~cm}$. The base of it overlies parasequence 1 and has a sharp boundary with the underlying sandstone lens. The lower part of parasequence 2 consists of $110 \mathrm{~cm}$ of dark-gray pelmicrite/packstone (Layer 3, shown on Figures 13 and 22) in which rugose corals and Amphipora are present, as can be seen in Figure 10. This was interpreted to represent open-circulation, subtidal conditions.

A thin section (112412-02) taken from Layer 3 stratigraphically above the corals contained ostracods, pellets, and (?) Tentaculites. The host rock for these allochems is fine-grained, dark-gray grainstone/intrasparite that is interbedded with packstone/intramicrite. The thickness of each of these layers was $\sim 15 \mathrm{~mm}$. This combination of characteristics was interpreted to indicate an intertidal environment (an 
intertidal flat) with less washed areas containing higher amounts of micrite. Overall, this thin section was classified as SMF 16-non-laminated.

In the upper $40 \mathrm{~cm}$ of Layer 3, the dark gray limestone becomes packstone/biopelmicrudite. There are more rugose corals in the middle of the layer, and at the top there is a 25 -cm-thick cap of densely packed Amphipora (Fig. 22). This was interpreted as a shallow, open lagoonal facies (SMF 8). Thin sections taken from the top of the packstone layer (112412-03, 112412-09) also contained Amphipora and were classified as SMF 8 and interpreted as subtidal.

The boundary between the 110-cm-thick bed (Layer 3) and the overlying $65-\mathrm{cm}-$ thick mudstone above (Layer 4) is sharp.

Field observations of the 65 -cm-thick medium-gray to medium-dark-gray to olive-gray mudstone bed (Layer 4) stratigraphically above this Amphipora-rich cap include thin-bedded to laminated carbonate with isolated solitary corals, as seen in Figures 13 and 22.

A thin section taken from the base of Layer 4 (LBG5B) contained laminated unfossiliferous mud, and was classified as SMF 19. The lack of bioturbation indicates few burrowing organisms present during and after deposition. Observations in the field stratigraphically above LBG5B included local solitary corals, indicating a short interval of normal marine, subtidal conditions. Thin sections taken from the middle of Layer 4 (LBG1B, LBG3B) also contained laminated, unfossiliferous mud. The three thin sections were interpreted to represent upper intertidal ponds. They were interpreted to record transition from the underlying subtidal lagoon preserved in Layer 3 to a shallower 
environment, followed by subtidal conditions, which were followed in turn by a shallower environment (Fig. 22).

The stratigraphically highest thin sections within the mudstone bed (LBG9B, LBG10B) were composed of unlaminated micrite. These samples were classified as SMF 23. The succession of microfacies from 19 to 23 was interpreted to represent successively shallower intertidal environments within the $65-\mathrm{cm}$-thick mudstone bed (Fig. 22).

A thin section (LBG8B, shown in Figures 13 and 22) made at the boundary between the mudstone and overlying sandstone bed contained sand-sized quartz grains in micritic matrix, as well as micritic intraclasts in pseudospar. The intraclasts accounted for approximately $25 \%$ of the thin section. This thin section thus had characteristics of both sandstone and wackestone, and the uppermost carbonate sub-layer between sandy sub-layers was interpreted to be from a crust that formed during a brief period of exposure. This thin section was classified as SMF 21 and was inferred to represent upper intertidal conditions, such as an upper intertidal pond or the landward edge of a tidal flat.

Layer 4 is capped by mudstone with red laminations that separate the gray mudstone from the overlying layer.

Stratigraphically above the mudstone is a sandstone layer (Layer 5, shown in Figures 13 and 22), with no preserved fossils apparent either in the field or in thin section. This was interpreted as further shallowing (above the upper intertidal pond) into supratidal or terrestrial conditions. The bottom boundary of the 10-cm-thick sandstone bed is sharp, but the top boundary is gradational. 
This peritidal parasequence is $185 \mathrm{~cm}$ thick. The subtidal portion contains one sub-environment, though the intertidal portion contains more than one. The subtidal portion could represent a shallowing of environment. The lagoonal facies could have been caused by flooding. Slow infilling of the lagoon could account for transitions from lagoon (SMF 8) to tidal pond (SMF 19) prior to deepening into open marine subtidal conditions. Shallowing to an evaporative tidal pond (SMF 23) and then into supratidal conditions could have occurred as the ocean regressed or as the coastline prograded. Figure 22 shows an interpreted depth curve for Parasequence 2.

\section{Parasequence 3}

Parasequence 3 is a thinner parasequence at only about $80 \mathrm{~cm}$ thickness, extending from $265 \mathrm{~cm}$ to $345 \mathrm{~cm}$ above the base of the measured section (Table 6). The boundary between Layer 5 (capping Parasequence 2) and Layer 6 in the overlying Parasequence 3 is gradational, indicating that the sandstone marking the parasequence boundary was slowly flooded. Figure 22 shows this gradual change on the interpreted depth curve.

The base of this parasequence is composed of $5 \mathrm{~cm}$ of mudstone with interbedded grainstone (Layer 6). A thin section taken from the very base of Layer 6 (LBG18B) was composed of bands of intrasparite with few (?) Tentaculites interstratified with micrite with some quartz silt. The gradation from the underlying sandstone makes boundary discernment at the base uncertain. The silty intrasparite preserved in LBG18B, classified as SMF 16-laminated, is distinctly different than carbonate preserved in thin sections 
taken from the overlying Layer 7. It was inferred that the 5-cm-thick Layer 6 preserves an intertidal environment.

Layer 6 is overlain by $70 \mathrm{~cm}$ of medium-gray to medium-dark-gray wackestone to grainstone (Layer 7, shown in Figures 13 and 22). A thin section in the middle part of Layer 7 (LBG13B) showed a deepening of environment compared to Layer 6 at the bottom of Parasequence 3. This thin section contained preserved (?) Tentaculites, crinoid fragments, and a broken brachiopod fragment in micrite (Fig. 17). It was classified as SMF 9 and interpreted to be subtidal. Field observations of the wackestone included stromatoporoids as well as isolated rugose corals. Figure 23 displays the stromatoporoids. The contact between the dark wackestone and the underlying silty micrite is unclear. Amphipora were preserved at the top of Layer 7. The upper $10 \mathrm{~cm}$ of the bed contain laminations, as can be seen in Figures 13 and 22. A thin section taken at the top of the bed (LBG16B, where the layer is a grainstone) included (?) Tentaculites but was predominantly composed of highly rounded micritic intraclasts in spar. The thin section resembles images of Wilson's SMF 16 with characteristic peloids composed of lime mud (Wilson, 1975). It was classified as SMF 16-non-laminated accordingly and interpreted to be from an intertidal channel.

A thin (5-cm-thick) sandstone bed (Layer 8) overlies Layer 7. The contacts for this sandstone bed were obscured in most locations. This represents a return to a supratidal environment. The sandstone is placed at the top of the parasequence. 


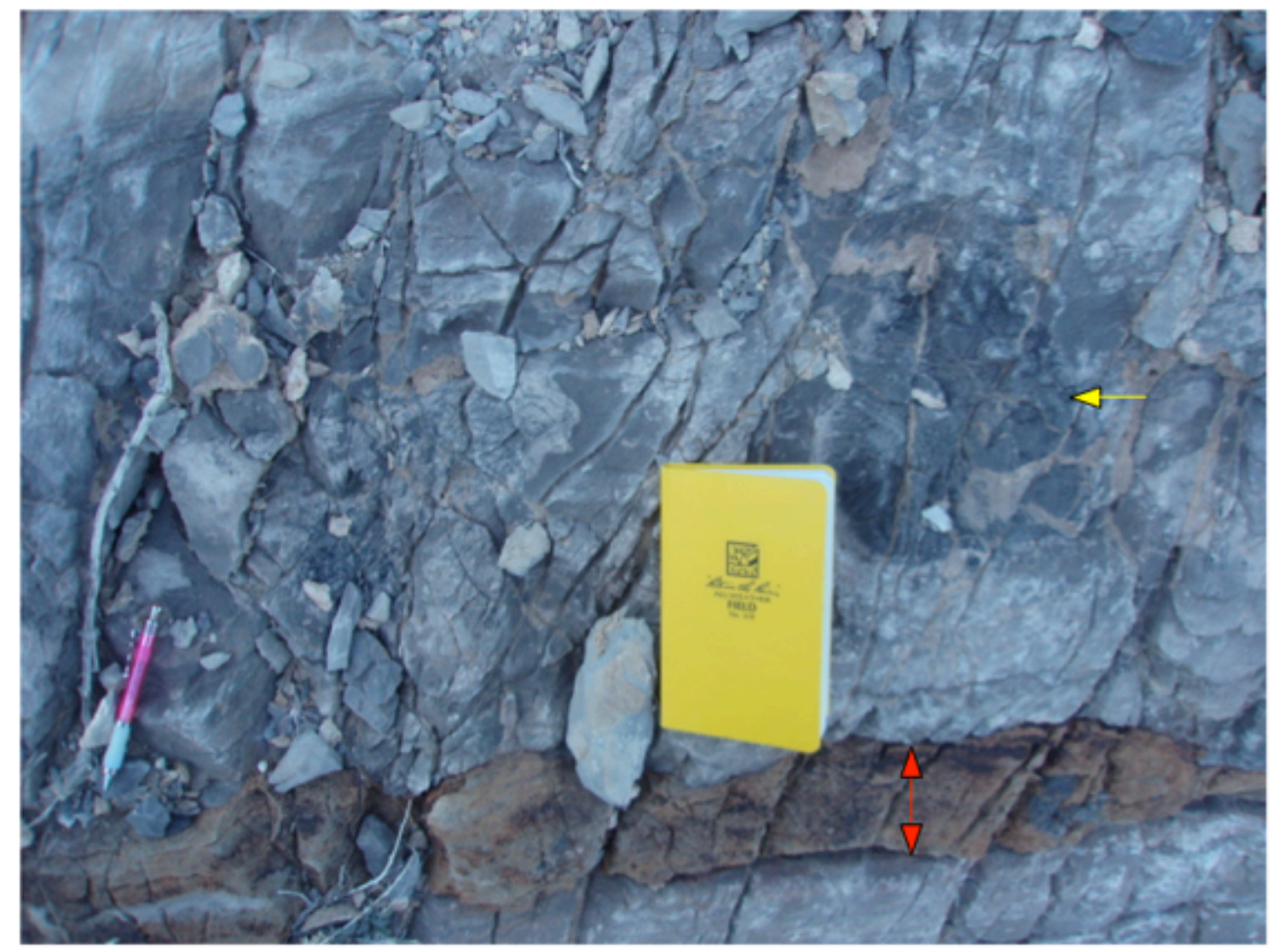

Figure 23. Sandstone lens (red arrows) overlain by stromatoporoid-bearing limestone in Parasequence 3 (field notebook is $19 \mathrm{~cm}$ tall). Stromatoporoid is black and fan-shaped, tapering to a point at top right corner of field notebook (middle of opposite side of stromatoporoid marked by yellow arrow).

This 80 -cm-thick parasequence represents an initial intertidal environment that is overlain by mostly subtidal beds that abruptly shallow at the top into successively shallower environments. Figure 22 displays the interpreted depth curve for this parasequence.

\section{Parasequence 4}

This parasequence has a thickness of $165 \mathrm{~cm}$. The boundary with the underlying sandstone is mostly obscured but is sharp where it can be found. The lower part of 
parasequence 4 is a fining upward wackestone bed (Layer 9, shown in Figures 13 and 22), ranging from medium-gray to medium-dark-gray in color. This 55 -cm-thick wackestone bed locally weathers to medium gray, medium light gray, olive gray or light olive gray. The bottom two-thirds of the bed are laminated.

The thin sections taken from the base of Layer 9 (LBG20B, LBG14BB, and LBG15BA) were composed of micrite with sparse Amphipora and ostracods, quartz silt, and micritic intraclasts with some micrite-recrystallized-as-pseudospar bands of $1 \mathrm{~mm}$ to $1 \mathrm{~cm}$ thickness. These thin sections were all classified as SMF 16-laminated and interpreted to be from an intertidal flat.

The wackestone also contains a sandstone lens $35 \mathrm{~cm}$ from the base of the bed. Figure 24 shows this lens. It is not laterally continuous within Layer 9 and is not included on Figure 22. Just above this lens, local rugose corals (Fig. 22) present in Layer 9 were interpreted to represent a brief subtidal interval. A thin section (112412-08) taken stratigraphically above the corals and sand lens but still within Layer 9 was similar to thin section LBG15BA although it contained more intraclasts. This thin section was composed of sand-sized micritic intraclasts in recrystallized micrite. Thin section 112412-08 also contained quartz silt. $112412-08$ was also classified as SMF 16laminated.

Layer 9 was interpreted to represent a shallow intertidal environment such as an intertidal flat, followed by normal marine subtidal conditions, which are followed in turn by an intertidal environment. The laminations continue up-section. 


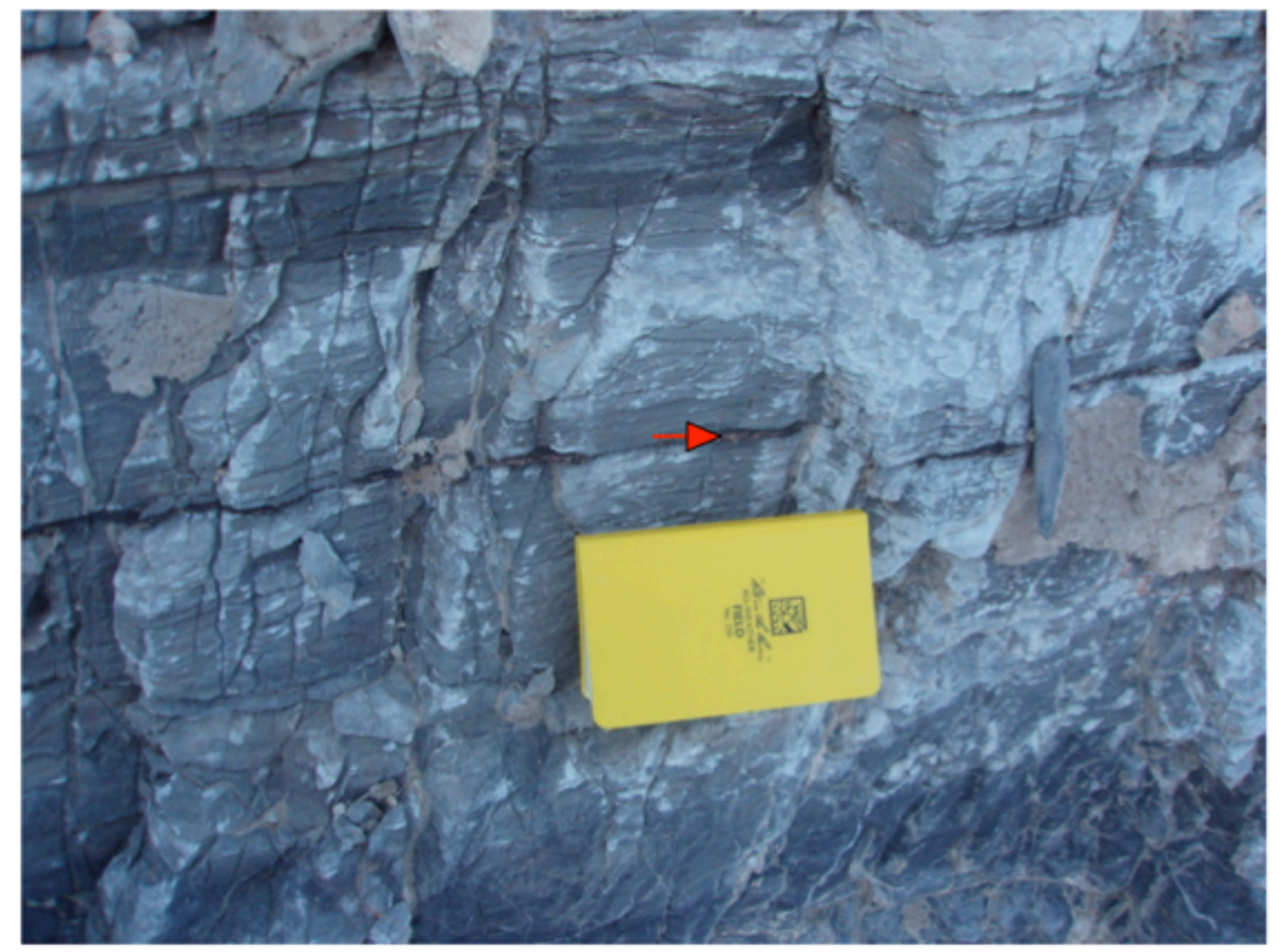

Figure 24. Sand lens (red arrow) above field notebook in Parasequence 4 (field notebook $19 \mathrm{~cm}$ from left to right).

Overlying Layer 9 is a fine-grained, medium-gray to medium-dark-gray grainstone (Layer 10, shown in Figures 13 and 22). Layer 10 weathers in places to medium light gray. The boundary between the grainstone and the underlying wackestone is sharp. In the field, the 80 -cm-thick grainstone bed appears almost sugary in texture, though petrographic examinations displayed the fine grain size of the carbonate.

Thin sections taken from Layer 10 (112412-04, LBG23B, LBG22B, LBG25B) were primarily $100 \mu \mathrm{m}$-sized micritic intraclasts in spar. The first of those thin sections was classified as SMF 16-laminated, and the remaining thin sections taken from this layer 
were classified as SMF 16-non-laminated. All were considered to be intertidal. The SMF 16-non-laminated samples were interpreted to represent more frequent submersion of the original sediment and a more turbulent environment, and potentially represent slightly deeper conditions (such as an intertidal channel). An intertidal channel could collect the intraclasts broken and washed along a tidal flat, as well as allow for rounding via tidal action and winnowing of mud. It would represent the deepest of the intertidal environments. The samples were collected across a 10-m lateral span within the same bed, and these samples were thought to represent a series of channels within that lateral expanse cutting through an intertidal flat complex over time.

The grainstone (LBG25B) is overlain by $5 \mathrm{~cm}$ of laminated dolomite (Layer 11) that weathers light olive gray. The boundary between these beds is obscured. This layer could represent a supratidal environment.

Capping the parasequence is a dark-gray to medium-dark-gray, 25-cm-thick sandstone bed (Layer 12) that weathers to moderate-yellowish-brown, moderate-brown, and medium-light-gray. This was inferred to represent an influx of terrigenous material and thus suggests supratidal conditions.

The transition between Layer 9 and Layer 10 represents a change from a succession of various upper intertidal and subtidal environments, such as intertidal flats, to another intertidal environment dominated by intertidal channels. Overlying this intertidal flat complex, supratidal conditions were preserved at this location in Layers 11 and 12. Figure 22 displays the interpreted depth curve for Parasequence 4.

The basal boundary of the parasequence is obscured. 


\section{Parasequence 5}

Parasequence 5 is $100 \mathrm{~cm}$ thick in the measured section. At the base of this parasequence is a dark-gray to medium-dark-gray mudstone (Layer 13, shown in Figures 13 and 22). This 15 -cm-thick bed terminates in a sharp boundary at $525 \mathrm{~cm}$ above the base of the measured section. This layer was interpreted to record a sudden transgression of the ocean. In the field it was observed that Layer 13 contained scattered rugose corals midway up the bed and Amphipora at the top. Figure 25 displays the isolated nature, small size, and horizontal orientation of these fossils.

Thin sections taken from within Layer 13 (112412-07, LBG28B, LBG29BB) were fossiliferous micrites and contained quartz silt, (?) Tentaculites, ostracods and crinoid fragments. They were considered to represent an open marine environment and were classified as SMF 9.

The dark-gray to medium-dark-gray Layer 13 has a gradational boundary with the overlying Layer 14. Layer 14 is a medium-dark-gray to medium-gray mudstone to grainstone that is $145 \mathrm{~cm}$ thick. As is shown in Figures 13 and 22, the base of Layer 14 is laminated mudstone and it grades upward into medium-gray grainstone that is thinly bedded.

A thin section (LBG36B) was taken $5 \mathrm{~cm}$ from the base of Layer 14. It was classified as SMF 19 and was considered to be an intertidal pond. A thin section taken from the top of Layer 14 (LBG39B) was composed of micritic intraclasts in spar. LBG39B also contained Amphipora. 


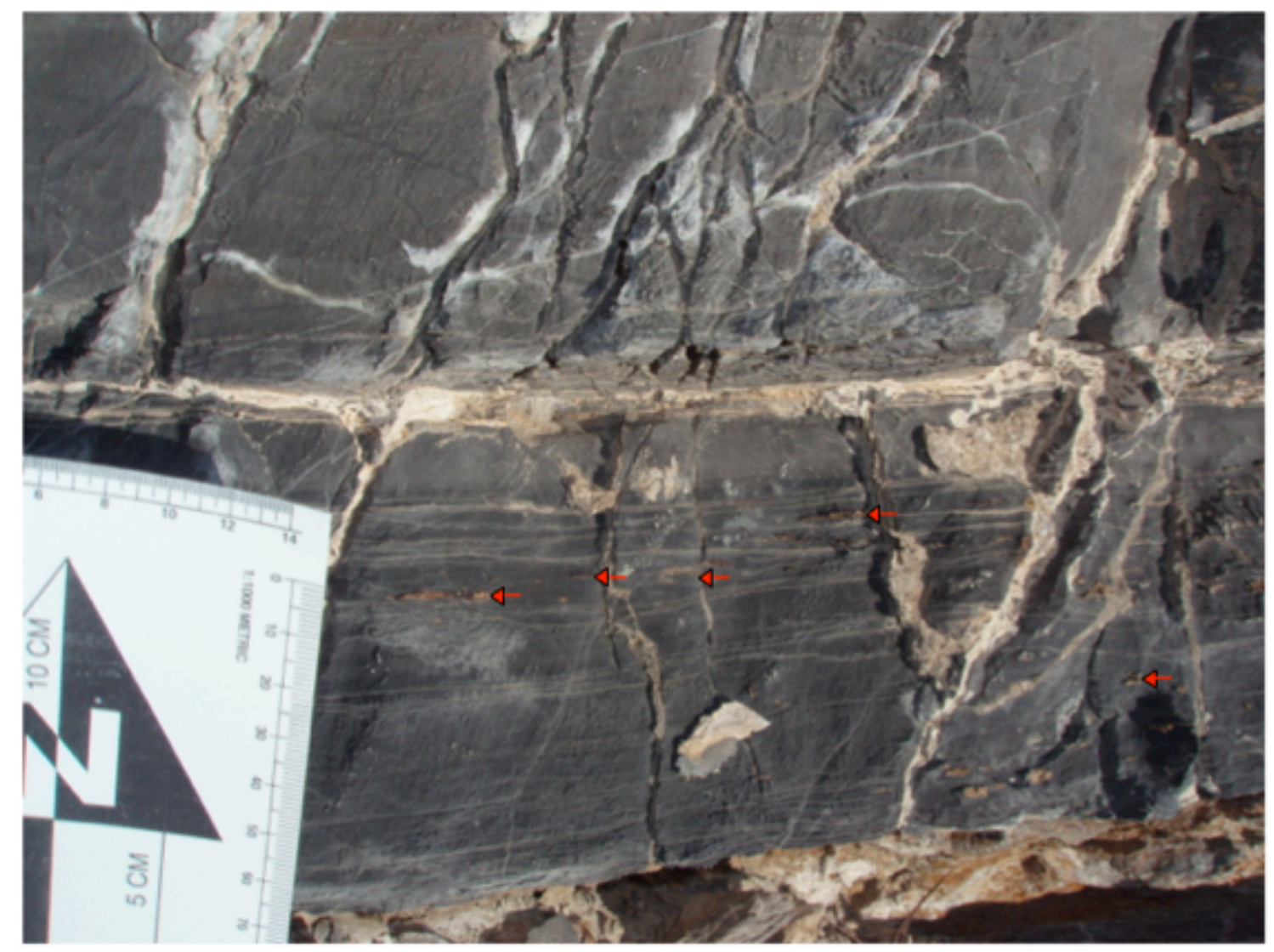

Figure 25. Rugose corals (red arrows) in Parasequence 5 (black arrow head $5 \mathrm{~cm}$ tall).

The thin section (LBG39B) was classified as SMF 16-non-laminated and was used to determine where Layer 14 changes from mudstone to grainstone.

This parasequence was thought to represent a generally shallowing-upward transition from open marine conditions to an upper intertidal pond and then to deepen very slightly into an intertidal channel. Unlike other parasequences described in this section, a sandstone layer does not cap Parasequence 5. Figure 22 displays the interpreted depth curve for this parasequence and the lack of significant changes in depth within Layer 14. 


\section{Parasequence 6}

Parasequence 6 is $65 \mathrm{~cm}$ thickness in the measured section. Rugose corals and stromatoporoids were observed in the field within Layer 15. The field observations of preserved fossils were interpreted as indicating subtidal conditions, so the transition from Layer 14 to Layer 15 was interpreted to be a flooding surface and a parasequence boundary at $610 \mathrm{~cm}$ above the base of the measured section. A thin section taken at the top of Layer 15 (LBG40BB) contained (?) Tentaculites, along with sand-sized micritic intraclasts in spar. This thin section was classified as SMF 16-non-laminated and interpreted to demonstrate intertidal conditions such as an intertidal channel. Figures 13 and 22 display the sample locations within the layer as well as the fossils observed in this layer.

Overlying Layer 15 is a 5-cm-thick sandstone bed (Layer 16) that weathers brownish-black or brownish-gray. The boundary between Layer 16 and the underlying Layer 15 is sharp. The sandstone was thought to be the top of a parasequence.

Most of the parasequence consists of medium-gray grainstone and was interpreted as a normal marine setting overlain by an intertidal channel flooded by terrestrial sediment. Figure 22 displays the interpreted depth curve for Parasequence 6.

Given the isolated pockets of allochems in the top part of the parasequence, these fossils could have washed in from deeper environments and been preserved in the intertidal channel. 


\section{Parasequence 7}

This parasequence has a thickness of $83 \mathrm{~cm}$. The boundary with the underlying sandstone is gradational, and was placed at the base of the lowest limestone containing less than $30 \%$ sand. The stratigraphically lowest bed within this parasequence (Layer 17, shown in Figures 13 and 22) is a medium-gray to dark-gray mudstone to grainstone. In the field, this 80 -cm-thick mudstone bed weathers light olive gray. The middle of the bed is laminated. Amphipora was found in the upper half.

A thin section taken from the base of Layer 17 (LBG43B) contained quartz silt and sand and tourmaline within the micrite. Thin sections from stratigraphically higher in Layer 17 contained quartz silt in micrite (112412-05) as well as sand-sized micritic intraclasts in micrite recrystallized as spar (LBG45B). The latter thin section also contained a few Amphipora. It was sampled near the midpoint of the layer. These thin sections were classified as SMF 21, and were considered to represent an upper intertidal pond or otherwise intertidal marine environment with some subaerial exposure. They could also preserve the landward edge of an upper intertidal flat.

It is from the midpoint and stratigraphically higher that Layer 17 becomes a grainstone. A thin section sampled from the top of the layer (LBG44BB) contained sandsized micritic intraclasts in spar. Figure 26 is a photomicrograph of thin section LBG44BB, showing these micritic intraclasts. This thin section was also classified as SMF 16-non-laminated and was interpreted as from an intertidal channel. 


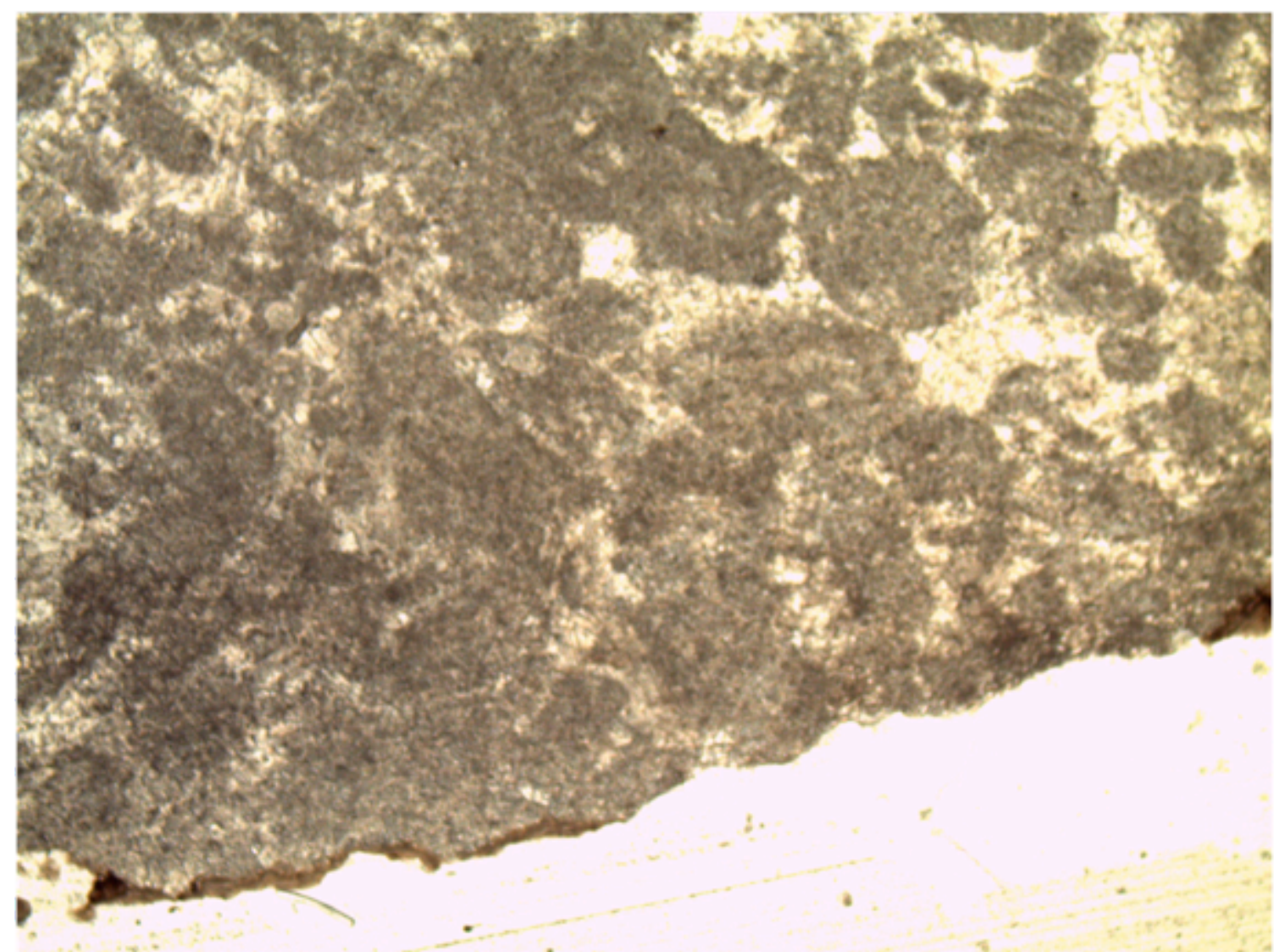

Figure 26. Thin section LBG44BB, showing dark micritic intraclasts in spar (field of view is $1.16 \mathrm{~mm}$ wide).

While Layer 17 was interpreted to represent intertidal environments across the entire thickness, the transition from SMF 21 to SMF 16-non-laminated represents intrasequence deepening as is seen in Parasequence 3.

Above a sharp boundary with Layer 17, a 3-cm-thick sandstone bed (Layer 18) caps the parasequence. This bed, weathering grayish-brown and pale-yellowish-brown to dark-yellowish-brown in color, represents an abrupt regression of the ocean and subsequent subaerial exposure. In the field, thin red films of what were thought to be algal material occur at the base of Layer 18. 
The top of parasequence 7 is $758 \mathrm{~cm}$ above the base of the measured section.

This parasequence lacks a subtidal component. It seems to record a succession of intertidal environments before shallowing into supratidal conditions, which could indicate that conditions at this time were consistently shallow. Figure 22 displays the interpreted depth curve for Parasequence 7.

\section{Parasequence 8}

Overlying parasequence 7 is an incomplete parasequence or one that has an obscured top surface. The lower portion (205 $\mathrm{cm}$ in the measured section) of this partial parasequence was studied. The remainder of the measured section contained no sandstones or sandy limestones (as were seen capping most of the previously described parasequences).

The base of parasequence 8 is characterized by laminated light-olive-gray to lightgray mudstone (Layer 19, shown in Figures 13 and 22). The contact with the underlying sandstone is gradational and was placed at the base of the lowest limestone containing less than $30 \%$ sand.

Thin sections of samples taken throughout the 25-cm-thick Layer 19 (LBG51B, LBG52B, LBG53B) contained no significant allochems except for local concentrations of silt-sized peloids in LBG53B. The base of this 25-cm-thick, light-gray to light-olive-gray bed is homogeneous and indistinctly laminated, and was interpreted as an evaporative intertidal pond (SMF 23). Laminated, fine-grained micrite was found farther up section, interpreted as an upper intertidal pond or the upper reaches of the evaporative tidal flat 
(SMF 21). This could be a short $(25 \mathrm{~cm})$ deepening-upward trend, though it lacks both subtidal and supratidal components.

The mudstone is overlain by a 125 -cm-thick medium-gray to dark-gray grainstone to wackestone (Layer 20). There are scattered rugose corals in the lower half of this bed (Figs. 13 and 22). The boundary between these two beds is sharp, indicating an abrupt transgression of the ocean and return to subtidal conditions. It was interpreted that this bed preserves an open marine subtidal environment.

A thin section taken from the middle of Layer 20 (LBG57B) was composed of sand-sized micritic intraclasts in spar. It was classified as SMF 16-non-laminated and was interpreted as an intertidal channel, though this environment was only apparent through thin section observations of the rounded intraclasts in cement. Up-section, solitary corals are again in evidence (Figs. 13 and 22). If supratidal conditions were achieved above the intertidal flat, they were not preserved in this location. This zone in the measured section could be another thin $(65 \mathrm{~cm})$ shallowing-upward parasequence.

Thin sections taken from the top of Layer 20 (112412-06, LBG56B) contained preserved Amphipora, and these allochems were preserved in micrite rather than spar. These thin sections were classified as SMF 8 and were considered to represent an open subtidal lagoon, but could also represent subtidal conditions with lower energy such as a tidal channel. The rock at this location is a biomicrite to a biomicrudite and is a wackestone under Dunham's (1962) criteria. Given this inferred deepening of environment, it is possible that a parasequence boundary was obscured within or at the base of the wackestone. 
A gradational transition is present between rocks with these subtidal characteristics and the overlying Layer 21. Thin sections (LBG58B, LBG60B) taken from the 55-cm-thick Layer 21 also contained Amphipora in micrite, though the allochems appear to be present in higher density in the field.

This high density is not confirmed by petrographic work, as the percentages of Amphipora ranged from 30-45\%. The openings in the Amphipora were mostly filled with spar. These thin sections from Layer 21 were classified as SMF 8, and were considered to be subtidal. The wackestone/biomicrite (LBG58B) to packstone/biomicrite (LBG60B) ranged in color from medium-dark-gray to medium-gray.

Above this wackestone bed, and above the limits of the measured section, additional limestone is present and there is no evidence of sandstone for at least $1 \mathrm{~m}$ of section. The boundary between the top of the packstone (Layer 21) and the overlying layer is gradational. The top of the parasequence is unclear.

Overall, Parasequence 8 could record several incomplete shallow, but deepening upward parasequences, or one incomplete parasequence that records a deepening upward trend. However, well defined flooding surfaces were not recognized. Figure 22 displays the interpreted depth curve for Parasequence 8.

\section{Interpreted Depositional History}

Parasequence 1 in the measured section shallows upward slightly at the top, recording a transition from a shallow upper intertidal environment such as an evaporative tidal pond to a supratidal or terrestrial environment (Fig. 22). The latter was inferred to 
have occurred as a result of relative sea level fall and terrigenous sediment flowing into the area. This parasequence lacks a clear subtidal environment.

Parasequence 2 has intra-sequence shallowing and deepening (Fig. 22). It begins in a limestone that records a transition from an inferred open marine environment into an intertidal flat. There is a transition above the intertidal channel into a lagoon. Intertidal ponds and open marine conditions were preserved above the subtidal conditions inferred in Layer 3, which are overlain by an upper intertidal pond/landward edge of an upper intertidal flat and then followed by a fall in relative sea level and influx of terrigenous sediment.

Parasequence 3 records deepening at the base but shallowing near the top (Fig. 22). Given the gradational boundary between the sandstone (Layer 5) of the underlying parasequence and Layer 6, this was interpreted as slow flooding of the supratidal environment into an intertidal flat and then an open marine subtidal environment. The majority of this parasequence is subtidal. The parasequence then records shallowing into an intertidal environment such as an intertidal channel before shallowing into supratidal conditions with an influx of terrigenous sediment.

The limestone layers in Parasequence 4 record an inferred series of intertidal and subtidal environments (Fig. 22) then a succession of intertidal channels. This intertidal flat complex is overlain by beds representing supratidal conditions, which were interpreted as a relative decrease in sea level and influx of terrigenous sediment.

Parasequence 5 is separated from Parasequence 4 by a sharp boundary that was interpreted to represent a sudden transgression of the ocean. This parasequence abruptly 
shallows upward, beginning with open marine subtidal conditions and then transitioning into an intertidal pond. The intertidal pond is overlain by an intertidal channel, which suggests that some very slight deepening occurred, though the change in water depth is not pronounced. The majority of this parasequence is intertidal (Fig. 22). No supratidal conditions were preserved.

Parasequence 6 is a shallowing upward parasequence, preserving transitions from an open marine subtidal environment into an intertidal channel and then supratidal conditions (Fig. 22). The majority of this parasequence is subtidal.

Parasequence 7 records a gradual deepening trend in the upper half, as shown in Figure 22. The sandstone capping Parasequence 6 shares a gradational boundary with the underlying Layer 17. The upper part of the sandstone was interpreted to record a slow transgression of the ocean. This deepening represents a marine flooding event, based on the change from the supratidal environment capping Parasequence 6 into the landward edge of an intertidal flat and then into an intertidal channel. The intertidal channel is overlain by terrigenous sediment, which was interpreted to record a sudden fall in relative sea level based on the sharp boundary between Layers 17 and 18 .

Parasequence 8 is an incomplete parasequence, as the parasequence top boundary is unclear. It records an overall deepening upward trend (Fig. 22). A gradational boundary with the sandstone capping Parasequence 7 was interpreted to record slow transgression of the ocean from inferred evaporative upper intertidal ponds to the edge of an intertidal flat. The environment deepens to open marine conditions before shallowing into an intertidal channel and then abruptly deepens into an open marine environment. 
This abrupt deepening could indicate the beginning of another parasequence, given that the upper half of Parasequence 8 records only subtidal environments. No supratidal environments were preserved within the upper part of Parasequence 8. 


\section{DISCUSSION}

\section{Parasequences and Patterns}

Within the Lost Burro Gap samples, one sandstone facies and six carbonate facies were recognized. Broadly, they were categorized as subtidal, intertidal, and supratidal. Subtidal environments were consistently submerged; intertidal environments had periodic subaerial exposure; and supratidal environments had only occasional submersion. Layers containing fossils such as corals and brachiopods were interpreted as subtidal, unless the fossils were interpreted to have washed in, whereas the sandstones are all interpreted as supratidal deposits. These three categories were recognized in the measured section, and there are multiple transitions between those three categories within the measured section. This is in agreement with the conclusions of Yang et al. (1995) about the nature of the deposits within Lost Burro Gap.

The individual facies were grouped into parasequences, based on both field observations and also on petrographic work. Some of the parasequences showed straightforward upward shallowing as predicted by Van Wagoner et al. (1988), but several showed deepening and then shallowing-upward trends. This intra-sequence deepening has been recognized in Devonian carbonates farther east, in the Antelope Range in Nevada (Johnson et al., 1996). The deposits from that study range from Early through Late Devonian in age, and include deposits that are coeval with the Lost Burro Formation. In another study, Elrick (1995) found similar initial deepening within peritidal (involving subtidal through supratidal environments) and completely subtidal parasequences in coeval carbonate deposits in eastern Nevada. The parasequences were 
classified there as transgressive-prone and typically showed initial deepening within an overall shallowing-upward succession of facies (Elrick, 1995). The Nevada transgressive-prone subtidal parasequences included tidal flats overlain by Amphiporarich subtidal deposits, a combination of characteristics that is also observed in the Lost Burro Gap samples.

The parasequence definition proposed in 2007 by Spence and Tucker, "A regionally significant meter-scale sedimentary package characterized by a succession of facies that may shallow-up, deepen-up then shallow-up, aggrade, or reflect constant water depth" (Spence and Tucker, 2007, page 807), would allow for intra-parasequence flooding. This alternative to the definition of Van Wagoner et al. (1988) would thus include the deepening within the Lost Burro parasequences.

In this study, a large number of individual facies was used to determine if a predictable pattern of environments is preserved in the Lost Burro Formation in order to compare these data with the conclusions of Yang et al. (1995). This was done in order to address the criticisms of Wilkinson et al. (1996) that statistically too few subenvironments were used to determine a pattern. The individual facies were listed in stratigraphic order to determine if a pattern exists within the measured section. Table 5 shows the SMF data used for this process, and Table 7 shows the individual transitions between sub-environments. The numeric headings refer to transitions between individual standard microfacies by number, by "N" when the sub-environment was determined to represent normal marine conditions based on field observations, and by "ss" when the bed was a sandstone. 


\section{TABLE 7. ENVIRONMENTAL TRANSITIONS WITHIN THE LOST BURRO GAP MEASURED SECTION}

\begin{tabular}{|c|c|c|c|c|c|c|c|c|c|c|c|c|c|c|c|c|}
\hline SMF & 23 & & & $\mathrm{~N}$ & 16 & 8 & 19 & 23 & 21 & ss & & 16 & 9 & 16 & ss & 16 \\
\hline$\Delta$ & $\Uparrow$ & & $\downarrow$ & $\Uparrow$ & $\Downarrow$ & $\Uparrow$ & $\Uparrow$ & $\Downarrow$ & $\Uparrow$ & $\Downarrow$ & & $\Downarrow$ & $\Uparrow$ & $\Uparrow$ & $\Downarrow$ & $\Uparrow$ \\
\hline SMF & ss & & N & 16 & 8 & 19 & 23 & 21 & ss & 16 & & 9 & 16 & ss & 16 & ss \\
\hline SMF & ss & 9 & 19 & 16 & & $\mathrm{~N}$ & 16 & ss & 21 & 16 & ss & 23 & 21 & $\mathrm{~N}$ & 16 & $\Sigma \Delta$ \\
\hline$\Delta$ & $\Downarrow$ & $\Uparrow$ & $\Downarrow$ & $\Downarrow$ & & $\Uparrow$ & $\Uparrow$ & $\Downarrow$ & $\Downarrow$ & $\Uparrow$ & $\Downarrow$ & $\Downarrow$ & $\Downarrow$ & $\Uparrow$ & $\Downarrow$ & $\Uparrow 13 \Downarrow 15$ \\
\hline SMF & 9 & 19 & 16 & $\mathrm{~N}$ & & 16 & ss & 21 & 16 & ss & 23 & 21 & $\mathrm{~N}$ & 16 & 8 & \\
\hline
\end{tabular}

The transition direction is represented in the table by the arrows, with the transitions representing the change from the facies in the upper row to the facies in the lower row (i.e., 23 to ss is shallowing upward [arrow up], and ss to $\mathrm{N}$ is deepening upward [arrow down]). The upper half of the table lists the first fourteen transitions, and the lower half continues with the remaining fourteen.

As shown in Table 7, no clear pattern of individual facies succession was evident within the $9.6 \mathrm{~m}$ measured section. Only five transitions between particular SMFs repeated in the measured section. Of those five pairs, only SMF 16 to sandstone and normal marine to SMF 16 occurred more than twice. In this respect, the samples taken from Lost Burro Gap provide data that support the findings of Wilkinson et al. (1996) rather than those of Yang et al. (1995). The data described here lead to a different interpretation than the work done by Yang et al. (1995). 


\section{Subtidal Reinterpretations}

The Lost Burro samples from this study are similar to those described by Yang et al. (1995). However, there is a difference in interpretation regarding the dark-gray to gray packstones with abundant Amphipora but without crinoids or corals. Yang et al. (1995) interpreted these to represent an open marine environment, whereas the samples from this study were interpreted to record a lagoonal environment, based on the stromatoporoid Amphipora, which many workers consider lagoonal (Kyle, 1981; Galli, 1985; Elrick, 1995; Witzke and Bunker, 1997; Hladil, 2007; Jannusch, 2008; Schneider et al., 2013).

Those areas that were not sampled and only observed in the field, containing corals and stromatoporoids, almost surely represent normal, open-marine conditions.

\section{Intertidal Reinterpretations}

Yang et al. (1995) classified sandstones as intertidal based on sedimentary structures that were observed (planar and trough cross-laminations, climbing ripple laminations, and planar to wavy laminations). In this study sandstones were considered to be supratidal based on the poor sorting and subangular rounding of the quartz grains. The sandstones did undergo periodic immersion, as indicated by the carbonate mud matrix, but the microcline grains present do not indicate significant interaction with sea water. 


\section{Shoaling Index}

Wilkinson et al. (1997) made reference to a shoaling index (SI), which is the percentage of transitions between paleoenvironments within a measured section that show a shallowing-upward trend in comparison to the total number of transitions. The section measured at Lost Burro Gap was analyzed in order to determine a shoaling index. Transitions between environments were tabulated using both petrographic data and field observations. Table 7 displays the transition data.

The measured section contained 28 total transitions, and 13 of them were shallowing-upward. Some transitions were questionable in terms of depth change; for example, the transition from SMF 23 to SMF 21 is slight as both were considered upper intertidal environments, but the transition is counted in the deepening category. This gives an SI of $46.4 \%$. If this transition (23 to 21 ) is instead considered as shallowing upward, the SI changes to $53.6 \%$. This is not significantly higher in value than the previous calculation, and does not change the overall conclusion that the shoaling index does not indicate an overall shallowing-upward trend within the sample set. The SI value should be higher in order to indicate a convincing trend. Wilkinson et al. (1997) used an example with an SI of $78.9 \%$ from a 20 -element succession as a convincing shallowing upward trend. In examining data from Cambro-Ordovician cycles in Virginia with SI values near 50\%, Wilkinson et al. (1997) found that this reflected abrupt transitions between rock types more than shallowing-upward facies changes. The data from this study are under $50 \%$ and thus not suggestive of an overall shallowing upward trend. 
If Wilkinson et al.'s (1997) calculation was modified so that the eight flooding surfaces (parasequence boundaries) are disregarded, the modified SI was $61.9 \%$. This is significantly higher than the shoaling index calculated with parasequence boundaries, but is still $17 \%$ lower than the 20 -element succession value calculated by Wilkinson et al. (1997).

Wilkinson et al. (1996) calculated critical significance levels using Markovian analysis to assess the statistical occurrence of shallowing upward in carbonate parasequences. It was not possible to conduct a similar calculation in this study because the number of elements in this measured section is too low. 


\section{CONCLUSIONS}

A re-examination of the Lost Burro Formation exposed in Lost Burro Gap was done in order to evaluate the different conclusions reached by Yang et al. (1995) and Wilkinson et al. (1996) regarding the nature of facies transitions in these rocks. Carbonate and sandstone samples were collected and made into 57 thin sections. This information was combined with field observations in order to determine the paleoenvironments of the rocks and to see if any systematic ordering of environments is present within the measured section.

The study led to the recognition of six standard microfacies (SMFs) within the carbonate rocks. Of these, two were considered subtidal and four were considered intertidal. The sandstones were interpreted to represent supratidal conditions. Within the measured section, eight parasequences have been identified.

These parasequences conformed to the parameters in the definition by Spence and Tucker (2007) of a parasequence in that they were not all strictly shallowing upward. Five of the seven parasequences showed initial or mid-sequence deepening within an overall shallowing upward trend. Not all parasequences involved subtidal environments. This intra-sequence deepening was not predicted by field observations, which suggested a simpler interpretation of the studied beds.

The presence of parasequences confirms the lithologic interpretations of Yang et al. (1995), though the particulars of several environments were interpreted differently between that study and this one. While parasequences are present, the assertions of Wilkinson et al. (1996) were also validated in that recognizing a larger number of sub- 
environments did not produce a discernible pattern of paleoenvironments. Calculation of a shoaling index did not indicate a repeatedly shallowing upward trend within parasequences identified in the measured section.

Given the presence of deepening within the majority of the parasequences, the commonly used definition of a parasequence, as defined by Van Wagoner et al. in 1988, is perhaps too narrow to cover the succession of environments observed in the Lost Burro Formation as exposed in Lost Burro Gap. The definition proposed by Spence and Tucker (2007), which also allows for deepening upward within a parasequence, deepening upward and then shallowing upward, as well as parasequences with almost constant water depth, is more applicable to this data set. 


\section{REFERENCES CITED}

Arnott, R.W.C., 1995, The parasequence definition - are transgressive deposits inadequately addressed?: Journal of Sedimentary Research, v. B65, p. 1-6.

Benbennick, D., 2006, Inyo County, California:

http://en.wikipedia.org/w/index.php?title=Inyo_County,_California\&oldid=63499802 7 (accessed December, 2014).

Benton, M.J., and Harper, D.A.T., 2009, Introduction to paleobiology and the fossil record: West Sussex, John Wiley \& Sons, 592 p.

Catuneanu, O., Abreu, V., Bhattacharya, J. P., Blum, M. D., Dalrymple, R. W., Eriksson, P. G., Fielding, C. R., Fisher, W.L., Galloway, W.E., Gibling, M.R., Giles, K.A., Holbrook, J.M., Jordan, R., Kendall, C.G.St.C., Macurda, B., Martinsen, O.J., Miall, A.D., Neal, J.E., Nummedal, D., Pomar, L., Posamentier, H.W., Pratt, B.R., Sarg, J.F., Shanley, K.W., Steel, R.J., Strasser, A., Tucker, M.E., Winker, C., 2009, Towards the standardization of sequence stratigraphy: Earth-Science Reviews, v. 92, p. 1-33.

Cornell, S. R., Brett, C. E., and Sumrall, C. D., 2003, Paleoecology and taphonomy of an edrioasteroid-dominated hardground association from tentaculitid limestones in the Early Devonian of New York: a Paleozoic rocky peritidal community: Palaios, v. 18, p. 212-224.

Dunham, R. J., 1962, Classification of carbonate rocks according to depositional texture, in Ham, W.E., ed., Classification of carbonate rocks, American Association of Petroleum Geologists Memoir 1, p. 108-121.

Elrick, M., 1995, Cyclostratigraphy of Middle Devonian carbonates of the eastern Great Basin: Journal of Sedimentary Research, v. B65, p. 61-79.

Flügel, E., 2004, Microfacies of carbonate rocks. analysis, interpretation, and application: Berlin Heidelberg, Springer-Verlag, 976 p.

Folk, R.L., 1980, Petrology of sedimentary rocks: Austin, Hemphill's, 170 p.

Folk, R.L., and Pittman, J.S., 1971, Length-slow chalcedony: a new testament for vanished evaporites: Journal of Sedimentary Petrology, v. 41, p. 1045-1058.

Galli, G., 1985, Depositional environments in the Devonian limestone succession of the Cima Ombladet (Carnic Alps, Italy): Facies, v. 12, p. 97-112. 
Hajlasz, B., 1974, Tentaculites of the Upper Silurian and Lower Devonian of Poland: Acta Palaeontologica Polonica, v. 19, p. 455-493.

Hladil, J.H., 2007, The earliest growth stages of Amphipora, in Hubmann, B. and Piller, W. E., eds., Fossil corals and sponges: Proceedings of the 9 th International Symposium on Fossil Cnidaria and Porifera, v. 17: Österreichische Akademie der Wissenschaften Schriftenreihe Erdwissenschaftliche Kommission, p. 51-65.

Holland, S., 2008, An online guide to sequence stratigraphy: http://strata.uga.edu/sequence/parasequences.html (accessed June 2014).

Jannusch, D. E., 2008, Systematics and paleoecology of Devonian stromatoporoids from the Cou Falls, Iowa City, and Osage Springs members, east-central Iowa [Ph.D. thesis]: Iowa City, University of Iowa, 265 p.

Johnson, J.G., Klapper, G., and Elrick, M., 1996, Devonian transgressive-regressive cycles and biostratigraphy, northern Antelope Range, Nevada: establishment of reference horizons for global cycles: Palaios, v. 11, p. 3-14.

Kyle, R.J., 1981, Geology of the Pine Point lead-zinc district: Chapter 11, in Wolf, K.H., ed., Handbook of strata-bound and stratiform ore deposits: New York, Elsevier Publishing Company, Regional Studies and Specific Deposits, v. 9, p.643-741.

Lucia, F.J., 1972, Recognition of evaporite-carbonate shoreline sedimentation, in Rigby, J.K., and Hamblin, W.K., eds., Recognition of ancient sedimentary environments: Society of Economic Paleontologists and Mineralogists, Special Publication 16, p. 160-191.

McAllister, J.F., 1952, Rocks and structure of the Quartz Spring area, northern Panamint Range, California: California Division of Mines and Geology Special Report 25, 38 p.

McAllister, J.F., 1956, Geology of the Ubehebe Peak Quadrangle, California: Geologic Quadrangle GQ-95, U.S. Geological Survey, scale 1:62,500.

Mitchum, R.J., 1977, Glossary of seismic stratigraphy, in Payton, C.E., Ed., Seismic stratigraphy - applications to hydrocarbon exploration: American Association of Petroleum Geologists Memoir 2, p. 205-212.

Montanez, I.P., and Osleger, D.A., 1993, Parasequence stacking patterns, third-order accommodation events, and sequence stratigraphy of Middle to Upper Cambrian platform carbonates, Bonanza King Formation, Southern Great Basin: Chapter 12, in Loucks, R.G. and Sarg, J. F., eds., Carbonate sequence stratigraphy, recent development and applications: American Association of Petroleum Geologists Memoir 57, p. 305-326. 
Schneider, C.L., Fenton, M.M., and Weiss, J.A., 2013, Grosmont Formation (Mikkwa Formation outcrop T106-R2W5-01) on Harper Creek, north-central Alberta (NTS 84J/01): Energy Resources Conservation Board, ERCB/AGS Open File Report 201217, 21 p, http://www.ags.gov.ab.ca/publications/OFR/PDF/OFR_2012_17.PDF.

Spence, G.H., and Tucker, M.E., 2007, A proposed integrated multi-signature model for peritidal cycles in carbonates: Journal of Sedimentary Research, v. 77, p. 797-808.

Stearn, C.W., Webby, B.D., Nestor, H., and Stock, C.W., 1999, Taxonomic occurrences of Amphipora/Amphiporidae/Amphiporida/Stromatoporoidea/Porifera: http://fossilworks.org (accessed March 2014).

Stevens, C.H., 1986, Evolution of the Ordovician through Middle Pennsylvanian carbonate shelf in east-central California: GSA Bulletin, v. 97, p. 11-25.

Stevens, C.H., 1991, Paleozoic shelf-to-basin transition in Owens Valley, California: in 1991 Fall Field Trip, Pacific Section SEPM and Coast Geological Society, Guidebook 69: Los Angeles, CA, Pacific Section SEPM and Coast Geological Society, $37 \mathrm{p}$.

Stevens, C.H., Klingman, D.S., Sandberg, C.A., Stone, P., Belasky, P., Poole, F.G., and Snow, J.K., 1996, Mississippian stratigraphic framework of east-central California and southern Nevada with revision of Upper Devonian and Mississippian stratigraphic units in Inyo County, California: USGS Bulletin 1988-J.

Thorez, J., Dreesen, R., and Streel, M., 2006, Famennian, in Dejonghe, L., ed., Current status of chronostratigraphic units named from Belgium and adjacent areas: Brussels, Geologica Belgica, 9/1-2, p. 27-45.

U.S. Geological Survey, 2014, National Map (USGS Topo):

http://basemap.nationalmap.gov/arcgis/rest/services/USGSTopo/MapServer/export?bbox $=-13165532.417362977 \% 2 \mathrm{C} 4342529.538231054 \% 2 \mathrm{C}$ -

$13045067.66078549 \% 2 \mathrm{C} 4420342.433025395 \&$ bboxSR $=$ \&layers $=\&$ layerDefs $=\&$ size $=12$ $00 \% 2 \mathrm{C} 800 \&$ image $\mathrm{SR}=\&$ format $=$ jpg\&transparent $=$ false $\& \mathrm{dpi}=\&$ time $=\&$ layerTimeOption $\mathrm{s}=\&$ dynamicLayers $=\& \mathrm{gdb}$ Version $=\&$ mapScale $=\& \mathrm{f}=\mathrm{html}$ (accessed December 2014).

Van Wagoner, J.C., 1985, Reservoir facies distribution as controlled by sea-level change: Society of Economic Paleontologists and Mineralogists Mid-Year Meeting, Golden, Colorado, p. 91-92. 
Van Wagoner, J.C., Posamentier, H.W., Mitchum, R.M., Vail, P.R., Sarg, J.F., Loutit, T.S., Hardenbol, J., 1988, An overview of the fundamentals of sequence stratigraphy and key definitions, in Wilgus, C.K., Hastings, B.S., Kendall, C.G.St.C., Posamentier, H.W., Ross, C.A., and Van Wagoner, J.C., eds., Sea-Level Changes: An Integrated Approach: Society of Economic Paleontologists and Mineralogists, Special Publication 42, p. 39-45.

Wilkinson, B.H., Diedrich, N.W., and Drummond, C.N., 1996, Facies succession in peritidal carbonate sequences: Journal of Sedimentary Research, v. 66, p. 1065-1078.

Wilkinson, B.H., Drummond, C.N., Rothman, E.D., and Diedrich, N.W., 1997, Stratal order in peritidal carbonate sequences: Journal of Sedimentary Research, v. 67, p. 1068-1082.

Wilson, J.L., 1975, Carbonate facies in geological history: New York, Springer-Verlag, $471 \mathrm{p}$.

Witzke, B.J., and Bunker, B.J., 1997, Sedimentation and stratigraphic architecture of a Middle Devonian (late Givetian) transgressive-regressive carbonate-evaporite cycle, Coralville Formation, Iowa area: in Klapper, G., Murphy, M.A., and Talent, J.A., eds., Paleozoic sequence stratigraphy, biostratigraphy, and biogeography: studies in honor of J. Granville ("Jess”) Johnson: Boulder, Colorado, Geological Society of America Special Papers, v. 321, p. 67-88, doi: 10.1130/0-8137-2321-3.67.

Yang, W., Harmsen, F., and Kominz, M.A., 1995, Quantitative analysis of a cyclic peritidal carbonate sequence, the Middle and Upper Devonian Lost Burro Formation, Death Valley, California - a possible record of Milankovitch climatic cycles: Journal of Sedimentary Research, v. B65, p. 306-322.

Youngquist, W., and Heinrich, M.A., 1966, Late Devonian conodonts from the Lost Burro Formation of California: Journal of Paleontology, v. 40, p. 974-975.

Zecchin, M., 2010, Towards the standardization of sequence stratigraphy: Is the parasequence concept to be redefined or abandoned?: Earth-Science Reviews, v.102, p. 117-119. 


\title{
APPENDIX 1: MEASURED SECTION
}

\author{
Lost Burro Gap
}

Location: N 36.74577, W 117.51772

Lost Burro Formation unit 3

Top of section; conformable contact with overlying limestone

Layer

Thickness Cumulative

$(\mathrm{cm})$ Thickness

21 Limestone (packstone with interbedded mudstone), (cm) predominantly medium-gray to light-olive-gray but medium-dark-gray at base, thin-bedded, finegrained, contains abundant Amphipora.

20 Limestone (wackestone with interbedded grainstone), dark-gray to medium-gray, finegrained, predominantly thin-bedded, contains micritic intraclasts, Amphipora in top $10 \mathrm{~cm}$, isolated rugose corals in bottom $30 \mathrm{~cm}$ and at $75 \mathrm{~cm}$ from base of layer, and (?) Tentaculites and micritic intraclasts between rugose corals in bottom half of layer. Laminations in top $5 \mathrm{~cm}$ and bottom $10 \mathrm{~cm}$ of layer.

19 Limestone (mudstone), light-gray to light-olivegray, fine-grained, predominantly laminated, contains silt-sized quartz and peloids.

18 Sandstone, olive-gray to medium-light-gray, contains carbonate cement, tourmaline and microcline grains. Weathers grayish-brown, paleyellowish-brown and dark-yellowish-brown.

17 Limestone (sandy mudstone to packstone to grainstone), medium-gray to medium-dark-gray to dark-gray to medium-light-gray from top to bottom, predominantly fine-grained, laminated in middle of layer and thin-bedded otherwise, contains sandsized quartz at base, micritic intraclasts and Amphipora in top $30 \mathrm{~cm}$. Carbonate weathers 
medium-light-gray, light-olive-gray and light-gray, and sandier base weathers brownish-black, palebrown, and moderate-yellowish-brown.

16 Sandstone, medium-gray, contains carbonate cement, tourmaline and microcline grains. Weathers brownish-gray, brownish-black, grayishbrown and moderate-yellowish-brown.

15 Limestone (grainstone), medium-gray to mediumlight-gray, very-fine-grained, predominantly thinbedded, contains micritic intraclasts, (?)

Tentaculites, rugose corals and a stromatoporoid in the top half. Weathers light-olive-gray, grayishbrown, brownish-gray, and pale-yellowish-brown.

14 Limestone (mudstone to grainstone), medium-gray to medium-dark-gray, very-fine-grained, predominantly thin bedded, contains micritic intraclasts, Amphipora, and laminations at the base of bed. Weathers medium-light-gray.

13 Limestone (mudstone), dark-gray to medium-darkgray, fine-grained, laminated, contains ostracods, crinoids, (?) Tentaculites, silt-sized quartz and scattered rugose corals. Weathers light-olive-gray, pale-yellowish-brown and very-pale-orange.

12 Sandstone, medium-dark-gray to dark-gray, carbonate cement, contains micritic intraclasts, microcline and tourmaline grains. Less resistant than overlying carbonate bed. Weathers moderatebrown, moderate-yellowish-brown, and mediumlight-gray.

11 Dolomite, medium-dark-gray, laminated, less resistant than underlying carbonate bed. Weathers light-olive-gray.

10 Limestone (packstone to grainstone), medium-darkgray to medium-gray, predominantly fine-grained, predominantly thick-bedded, contains micritic intraclasts, Amphipora, and (?) Tentaculites. Weathers medium-light-gray, medium-gray, and 
moderate-yellowish-brown.

$9 \quad$ Limestone (wackestone with interlaminated

mudstone), medium-dark-gray to medium-gray, fine-grained to very-fine-grained, predominantly laminated, contains micritic intraclasts, Amphipora, ostracods, silt-sized quartz and rugose corals.

Weathers medium-gray, medium-light-gray, olivegray, and light-olive-gray.

8 Sandstone, weathers dark-yellowish-orange and moderate-brown.

7 Limestone (grainstone to wackestone), medium-gray to medium-dark-gray, very-fine-grained, predominantly thick-bedded, contains (?) Tentaculites, micritic intraclasts, brachiopods, echinoderms, rugose corals, sand-sized quartz and stromatoporoids. Weathers light-olive-gray and medium-gray.

6 Limestone (mudstone with interbedded grainstone), medium-dark-gray, laminated, contains silt-sized quartz, micritic intraclasts and (?) Tentaculites. Weathers pale-yellowish-brown.

5 Sandstone, olive-gray, contains lime mud. Weathers dark-yellowish-orange, moderate-brown, duskyyellowish-brown and light-brown.

4 Limestone (mudstone), medium-gray to mediumdark-gray to olive-gray, fine-grained, thin-bedded to laminated, contains rugose corals. Weathers olivegray, medium-light-gray, and pale-yellowish-brown.

3 Limestone (wackestone to packstone, with interbedded grainstone), dark-gray, fine-grained, thick-bedded, contains ostracods, peloids, micritic intraclasts, (?) Tentaculites, Amphipora and rugose corals. Weathers medium-dark-gray.

2 Sandstone, lenticular bed. 
contains micritic intraclasts, sand- and silt-sized quartz grains, as well as Amphipora at very top of bed. Weathers medium-dark-gray.

Base of section; conformable contact with underlying sandstone 


\section{APPENDIX 2: SAMPLE DESCRIPTIONS}

LBG60B: Fine-grained, medium-gray mudstone/micrite overlain by packstone/biomicrite with 45\% Amphipora. SMF 8.

LBG58B: Layer of medium-dark-gray mudstone/micrite overlain and underlain by wackestone/biomicrite with 30\% Amphipora. SMF 8.

LBG56B: Fine-grained, medium-dark-gray wackestone/biomicrudite. $\sim 45 \%$ Amphipora, many $>2 \mathrm{~mm}$. SMF 8 .

112412-06: Medium-gray wackestone/biomicrite. 50\% Amphipora. SMF 8.

LBG57B: Indistinctly laminated, dark-gray grainstone/intrasparite with sand-sized micritic intraclasts (60\%) and (?) Tentaculites (2\%), interlaminated with mudstone/micrite. SMF 16-laminated.

LBG53B: Laminated, fine-grained, light-gray mudstone/micrite with fenestrae and local concentrations of silt-sized peloids in mudstone/micrite. SMF 21.

LBG52B: Fine-grained, light-olive-gray mudstone/micrite. $<1 \%$ silt-sized quartz. SMF 23.

LBG51B: Indistinctly laminated, fine-grained, light-olive-gray mudstone/micrite. SMF 23.

LBG50B: Olive-gray sandstone. Poorly sorted, bimodal rounding: coarse sand wellrounded to rounded and fine sand rounded to sub-angular. Few tourmaline inclusions in quartz, few oxidized pyrite crystals, few sand-sized micritic intraclasts. Carbonate mud matrix. Weathers grayish brown and pale yellowish brown. 
LBG47B: Medium-light-gray sandstone. Poorly sorted, bimodal rounding: sand-sized grains well rounded to rounded, silt-sized grains rounded to sub-angular. Few tourmaline, microcline, weathered pyrite grains. Few sand-sized micritic intraclasts, contains (?) Tentaculites fragments. Carbonate mud matrix. Weathers pale yellowish brown to dark yellowish brown.

LBG44BB: Medium-gray grainstone/intrasparite. Sand-sized micritic intraclasts (60\%). Weathers light olive gray. SMF 16-non-laminated.

LBG45B: Laminated, fine-grained, medium-dark-gray packstone/intramicrite. Sandsized micritic intraclasts (50\%). Few fenestrae and quartz silt grains. Very small fragments of Amphipora (3\%). Matrix recrystallized to pseudospar. Weathers light gray. SMF 21.

112412-05: Laminated, fine-grained, dark-gray mudstone/micrite and sandy mudstone/micrite. Sandy mudstone with poorly sorted sand-sized quartz $(15 \%$, subrounded to sub-angular) and sandy layers range in thickness from 1 to $2.5 \mathrm{~mm}$. Some oxidized pyrite grains. SMF 21.

LBG43B: Laminated mudstone/micrite with some very fine quartz sand, grading up into unlaminated mudstone/micrite. Mudstone is underlain by a thin layer of sandstone, poorly sorted, well-rounded to sub-angular, some oxidized pyrite grains and few tourmaline grains. Sandy portion weathers moderate yellowish brown. SMF 21. LBG41BA: Medium-gray sandstone. Poorly sorted, bimodal roundness: sand-sized grains well-rounded to rounded, silt-sized grains sub-rounded to sub-angular. Sand-sized micritic intraclasts, some of which contain (?) Tentaculites fragments, few tourmaline 
grains and oxidized pyrite grains. Carbonate mud matrix. Weathers moderate yellowish brown.

LBG42B: Medium-gray sandstone. Poorly sorted, bimodal roundness: sand-sized grains well-rounded to sub-rounded, silt-sized grains sub-rounded to sub-angular. Few tourmaline and microcline grains. Carbonate mud matrix. Weathers brownish gray and grayish brown.

LBG40BB: Very fine-grained, medium-gray grainstone/intrasparite. Sand-sized micritic intraclasts (50\%), (?) Tentaculites (1-2\%). Weathers light olive gray. SMF 16-nonlaminated.

LBG39B: Very fine-grained, medium-dark-gray grainstone/intrasparite. Sand-sized micritic intraclasts (45\%). Very small fragments of Amphipora (15\%). SMF 16-nonlaminated.

LBG36B: Laminated, very fine-grained, medium-dark-gray mudstone/micrite. Few siltsize quartz grains, few oxidized pyrite crystals. Weathers medium light gray. SMF 19. LBG29BB: Laminated, fine-grained, dark-gray mudstone/fossiliferous micrite. Ostracods, (?) Tentaculites and crinoid fragments (5\% together). Some silt-size quartz, some oxidized pyrite grains. Weathers light olive gray. SMF 9.

LBG28B: Laminated, fine-grained, dark-gray mudstone/fossiliferous micrite. Ostracods, crinoid stem fragments, (?) Tentaculites, and silt-sized quartz ( 1-2\% together). Weathers pale yellowish brown and very pale orange. SMF 9. 
112412-07: Laminated, fine-grained, dark-gray mudstone/fossiliferous micrite. (?)

Tentaculites, silt-sized quartz, and an ostracod (3\% together). Weathers pale yellowish brown and very pale orange. SMF 9.

LBG30B: Medium-dark-gray sandstone. Moderately sorted, well rounded to subrounded. Few tourmaline inclusions in quartz grains, few oxidized pyrite grains. Few sand-sized micritic intraclasts that contain (?) Tentaculites fragments. Carbonate mud matrix. Weathers moderate brown and moderate yellowish brown.

LBG31B: Medium-dark-gray sandstone. Poorly sorted, well rounded to sub-rounded. Few tourmaline grains. Several micritic intraclasts, some contain (?) Tentaculites fragments, some oxidized pyrite grains. Carbonate mud matrix. Weathers medium light gray and moderate yellowish brown.

LBG34BA1: Medium-dark-gray sandstone. Poorly sorted and well rounded to subangular, interlaminated with layers of well sorted and well rounded to sub-rounded medium sand to silt. Few pebble-sized micritic intraclasts, some contain (?) Tentaculites fragments (in poorly sorted layer). Few microcline grains (in well-sorted layer). Some oxidized pyrite grains throughout. Carbonate mud matrix. Weathers moderate yellowish brown.

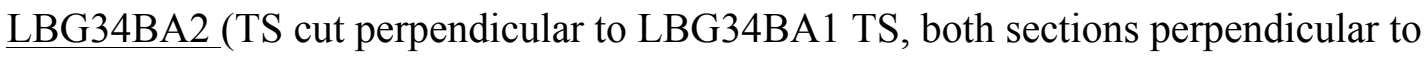
bedding and at same elevation within measured section): Medium-dark-gray sandstone. Poorly sorted, well rounded to sub-angular. Some microcline grains, few tourmaline grains, some oxidized pyrite grains, few micritic intraclasts, some contain (?) Tentaculites fragments. Carbonate mud matrix. Weathers moderate yellowish brown. 
LBG25B: Very fine-grained, medium-dark-gray grainstone/intrasparite. Sand-sized micritic intraclasts (25\%) with spar-filled vugs. Very small fragments of Amphipora (1-2\%). Weathers medium light gray. SMF 16-non-laminated.

LBG22B: Medium-dark-gray grainstone/intrasparite. Sand-sized micritic intraclasts (70\%) and Amphipora (3\%). Weathers medium gray. SMF 16-non-laminated.

LBG23B: Medium-gray grainstone/intrasparite. Sand-sized micritic intraclasts (75\%), one micritic intraclast $\sim 1 \mathrm{~cm}$ long. Few fragments of (?) Tentaculites. SMF 16-nonlaminated.

112412-04: Interlaminated medium-dark-gray packstone/intramicrite and mudstone/micrite. Packstone contains sand-sized micritic intraclasts (70\%), one clast $\sim 1 \mathrm{~cm}$ long, and few Amphipora. Packstone matrix recrystallized to pseudospar. Mudstone is laminated and fine-grained, and mudstone layers range in thickness from 0.35 to $0.8 \mathrm{~mm}$. Weathers medium light gray and moderate yellowish brown. SMF 16laminated.

112412-08: Interlaminated medium-dark-gray wackestone/intramicrite and mudstone/micrite. Wackestone contains sand-sized micritic intraclasts (50\%), one clast $>2 \mathrm{~mm}$ long, and few silt-sized quartz grains. Wackestone matrix recrystallized to pseudospar. Wackestone layers range in thickness from 0.6 to $1.6 \mathrm{~mm}$. Mudstone is fine-grained and unfossiliferous. Weathers medium gray. SMF 16-laminated. LBG15BA: Interlaminated very fine-grained, medium-dark-gray wackestone /intramicrite and mudstone/micrite. Wackestone contains sand-sized micritic intraclasts (50\%), $<1 \%$ ostracods and Amphipora, some silt-sized quartz grains, and few oxidized 
pyrite grains. Wackestone matrix recrystallized to pseudospar. Mudstone is laminated and fine-grained, and mudstone layers range in thickness from 0.4 to $1.8 \mathrm{~mm}$. Weathers olive gray. SMF 16-laminated.

LBG14BB: Interlaminated fine-grained medium-gray packstone/intramicrite and mudstone/micrite. Packstone contains sand-sized micritic intraclasts $(60 \%)$ with few Amphipora. Packstone matrix recrystallized to pseudospar. Mudstone is laminated and fine-grained, and contains some spar-filled burrows. Mudstone layers range in thickness from 0.8 to $2.5 \mathrm{~mm}$. Weathers medium light gray and light olive gray. SMF 16laminated.

LBG20B: Interlaminated very fine-grained medium-dark-gray wackestone/intramicrite and mudstone/micrite. Wackestone contains sand-sized micritic intraclasts $(50 \%)$, sparfilled vugs, and few Amphipora. Wackestone matrix recrystallized to pseudospar. Wackestone layers range in thickness from 0.3 to $2.8 \mathrm{~mm}$. Mudstone is laminated and very fine-grained. Weathers medium light gray. SMF 16-laminated. LBG16B: Very fine-grained, medium-gray grainstone/intrasparite. Sand-sized micritic intraclasts $(60 \%)$, echinoderm disc fragments and (?) Tentaculites (5\% together). Matrix recrystallized to pseudospar. Weathers light olive gray. SMF 16-non-laminated.

LBG13B: Very fine-grained, unlaminated, medium-dark-gray wackestone/biomicrite. Brachiopods, crinoid fragments, and (?) Tentaculites (11\% together). Some fine sand grains. Weathers medium gray. SMF 9.

LBG18B: Grainstone/intrasparite with sand-sized micritic intraclasts (30\%) and 1\% (?) Tentaculites interstratified with laminated, medium-dark-gray mudstone/micrite. Few 
quartz silt grains, few oxidized pyrite grains. Weathers pale yellowish brown. SMF 16laminated.

LBG4B: Olive-gray sandstone. Poorly sorted, well-rounded to sub-angular. Few tourmaline, microcline, oxidized pyrite grains. Carbonate mud matrix. Weathers dark yellowish orange and moderate brown.

LBG2B: Olive-gray sandstone. Poorly sorted and well rounded to sub-rounded laminae, interlaminated with layers of moderately sorted, well rounded to sub-angular fine sand and silt. Few microcline grains, oxidized pyrite grains. Carbonate mud matrix. Weathers dusky yellowish brown and light brown.

LBG8B: Interlayered fine-grained, medium-dark-gray wackestone/intramicrite and sandstone. Wackestone contains sand-sized micritic intraclasts (40\%) and quartz silt, and matrix is recrystallized to pseudospar. Sandstone is poorly sorted and well-rounded, contains some quartz silt, few tourmaline grains, few oxidized pyrite grains in a carbonate mud matrix. Sandstone layers range in thickness from 1.0 to $4.3 \mathrm{~mm}$. Weathers olive gray. SMF 21.

LBG10B: Fine-grained, medium-gray mudstone/micrite interbedded with siltstone. Mudstone contains silt-sized quartz grains ( $\sim 3 \%)$, few sand grains. Siltstone layers are predominantly silt-sized quartz grains, well sorted, well rounded to sub-angular, with a carbonate mud matrix. Uppermost siltstone layer is poorly sorted sand and silt, well rounded to sub-rounded. Weathers pale yellowish brown. SMF 23.

LBG9B: Fine-grained, olive-gray mudstone/micrite. Quartz silt (5\%). Chert nodules with length-slow chalcedony. SMF 23. 
LBG3B: Laminated, medium-gray mudstone/micrite. Few oxidized pyrite grains. SMF 19.

LBG1B: Laminated, medium-dark-gray mudstone/micrite. Few oxidized pyrite grains. Weathers olive gray and medium light gray. SMF 19.

LBG5B: Laminated, medium-dark-gray mudstone/micrite. Few oxidized pyrite grains. Weathers medium light gray. SMF 19.

112412-09: Fine-grained, dark-gray packstone to wackestone/biopelmicrudite. Amphipora (50\%), peloids (10\%). Weathers medium dark gray. SMF 8. 112412-03: Fine-grained, dark-gray packstone/biopelmicrudite. Amphipora and ostracods (60\% together). Some oxidized pyrite crystals. SMF 8. 112412-02: Burrowed, fine-grained, dark-gray grainstone/intrasparite, peloids (50\%), ostracods and Tentaculites (15\% together) with local concentrations of micritic intraclasts in packstone/intramicrite. Few oxidized pyrite crystals. SMF 16-non-laminated. 112412-01A: Unlaminated, fine-grained, dark-gray wackestone/intramicrite. Both siltand sand-sized quartz grains $(<5 \%)$, sand-sized micritic intraclasts $(25 \%)$, and few oxidized pyrite crystals. Weathers medium dark gray. SMF 23. 